\title{
Atlantic Water advection vs. glacier dynamics in northern Spitsbergen since early deglaciation
}

\author{
Martin Bartels ${ }^{1}$, Jürgen Titschack ${ }^{1,2}$, Kirsten Fahl ${ }^{3}$, Rüdiger Stein ${ }^{3}$, Marit-Solveig Seidenkrantz ${ }^{4}$, \\ Claude Hillaire-Marcel ${ }^{5}$, and Dierk Hebbeln ${ }^{1}$ \\ ${ }^{1}$ MARUM - Center for Marine Environmental Sciences, University of Bremen, 28359 Bremen, Germany \\ ${ }^{2} \mathrm{SaM}$ - Senckenberg am Meer, Marine Research Department, 26382 Wilhelmshaven, Germany \\ ${ }^{3}$ Alfred Wegener Institute for Polar and Marine Research, 27568 Bremerhaven, Germany \\ ${ }^{4}$ Centre for Past Climate Studies and Arctic Research Centre, Department of Geoscience, Aarhus University, \\ 8000 Aarhus C, Denmark \\ ${ }^{5}$ GEOTOP - Université du Québec à Montréal, Montreal, H3C 3P8, Canada
}

Correspondence to: Martin Bartels (mbartels@marum.de)

Received: 23 March 2017 - Discussion started: 27 March 2017

Revised: 15 September 2017 - Accepted: 16 October 2017 - Published: 30 November 2017

\begin{abstract}
Atlantic Water (AW) advection plays an important role in climatic, oceanographic and environmental conditions in the eastern Arctic. Situated along the only deep connection between the Atlantic and the Arctic oceans, the Svalbard Archipelago is an ideal location to reconstruct the past AW advection history and document its linkage with local glacier dynamics, as illustrated in the present study of a $275 \mathrm{~cm}$ long sedimentary record from Woodfjorden (northern Spitsbergen; water depth: $171 \mathrm{~m}$ ) spanning the last $\sim 15500$ years. Sedimentological, micropalaeontological and geochemical analyses were used to reconstruct changes in marine environmental conditions, sea ice cover and glacier activity. Data illustrate a partial break-up of the Svalbard-Barents Sea Ice Sheet from Heinrich Stadial 1 onwards (until $\sim 14.6 \mathrm{ka}$ ). During the Bølling-Allerød $(\sim 14.6-12.7 \mathrm{ka})$, AW penetrated as a bottom water mass into the fjord system and contributed significantly to the destabilization of local glaciers. During the Younger Dryas $(\sim 12.7-11.7 \mathrm{ka})$, it intruded into intermediate waters while evidence for a glacier advance is lacking. A short-term deepening of the halocline occurred at the very end of this interval. During the early Holocene $(\sim 11.7-7.8 \mathrm{ka})$, mild conditions led to glacier retreat, a reduced sea ice cover and increasing sea surface temperatures, with a brief interruption during the Preboreal Oscillation $(\sim 11.1-10.8 \mathrm{ka})$. Due to a $\sim 6000$-year gap, the midHolocene is not recorded in this sediment core. During the late Holocene $(\sim 1.8-0.4 \mathrm{ka})$, a slightly reduced AW inflow
\end{abstract}

and lower sea surface temperatures compared to the early Holocene are reconstructed. Glaciers, which previously retreated to the shallower inner parts of the Woodfjorden system, likely advanced during the late Holocene. In particular, topographic control in concert with the reduced summer insolation partly decoupled glacier dynamics from AW advection during this recent interval.

\section{Introduction}

In the context of the ongoing global warming, the Arctic is gaining increasing attention from the scientific community and the general public (e.g. IPCC, 2014; Masson-Delmotte et al., 2013). This is primarily motivated by extreme events like the 2012 sea ice minimum, the declining summer sea ice cover of recent decades (Stroeve et al., 2012) and the significant contribution of melting Arctic glaciers to the rising global sea level (e.g. Alley et al., 2005; Gregory and Huybrechts, 2006; IPCC, 2014; Overpeck et al., 2006). The Arctic is extremely sensitive to climatic changes and due to various feedback mechanisms, it is warming twice as fast as the global mean - a phenomenon commonly called the Arctic amplification (Serreze and Barry, 2011). These drastic changes in the Arctic also likely have far-reaching impacts. Several studies draw a connection to climate phenomena (especially severe winters) at lower latitudes (e.g. Cohen, 2016; 
Cohen et al., 2014; Kug et al., 2015; Mori et al., 2014; Overland et al., 2015; Overland, 2015), although, causal linkages between these concurrent events are open to discussion (e.g. McCusker et al., 2016; Meleshko et al., 2016; Overland et al., 2016).

While various studies suggest that these recent climate changes are induced by human activities (e.g. Abram et al., 2016; IPCC, 2014), it still remains unclear to which extent natural mechanisms may be involved. Instrumental climate data rarely cover more than the last century; sea ice observations using satellites did not even start before late 1978 (Stroeve et al., 2012). Hence, data reaching far beyond these instrumental time series are needed to assess the full range of natural environmental variability, especially the linkage between oceanic current changes and glacier instability. Sedimentary records covering centuries and millennia offer such archives of natural climate variations during preindustrial times, i.e. without any significant anthropogenic impact. Also in the geological past, the Arctic has experienced periods of warming when ice shelves broke up and glaciers melted dramatically. The transition from the Pleistocene to the early Holocene, and especially the Holocene Thermal Maximum (HTM), when enhanced northward advection of Atlantic Water (AW; e.g. Sarnthein et al., 2003) and maximum insolation were recorded at high northern latitudes (Berger and Loutre, 1991), may help demonstrate ocean-glacier interactions under a fast warming trend, possibly comparable to the ongoing global warming.

Today, the advection of warm ocean currents is a main contributor to basal glacier melting in both hemispheres, which eventually leads to global sea level rise (e.g. Cook et al., 2016; Luckman et al., 2015; Straneo et al., 2010). Being situated at the only deep-sea gateway that connects the Arctic Ocean with the North Atlantic, the Svalbard Archipelago is an ideal location to investigate changes in the inflow of relatively warm AW into the Arctic Ocean and its influence on the sea ice regime, regional glacier activity and climatic conditions. This passage - the Fram Strait - is a major gateway for heat advection to high northern latitudes as well as for sea ice export from the Arctic towards lower latitudes. The majority of Arctic sea ice ( 90\%; Rudels, 2009) and about $50 \%$ of its total freshwater (during the time period 19792001; Serreze et al., 2006) are exported through the Fram Strait. More recent studies report an increasing liquid freshwater export of almost $4 \%$ but decreasing sea ice export of $\sim 17 \%$ for the time period 2000-2010 compared to the previous 2 decades (e.g. Haine et al., 2015). Due to circulation of the northernmost branch of the North Atlantic Current along its western slope, Svalbard is bathed by warmer waters than any other Arctic location (Fig. 1a, b), providing the area with a relatively mild climate. In the present study, we chose a site at the mouth of Woodfjorden (Fig. 1c), located at the northern margin of Svalbard where the main branch of AW enters the Arctic Ocean, for the documentation of ocean-ice interactions from deglacial times to the present. In this fjord system, which is fed today by tidewater glaciers, enhanced sedimentation rates offer a high temporal resolution.

During the Late Glacial Maximum ( 21-18 ka; Svendsen et al., 2004), Svalbard's glaciers and ice caps were part of the Svalbard-Barents Sea Ice Sheet. This grounded ice sheet covered the entire Barents Sea and expanded as far as the shelf break of Svalbard (Landvik et al., 1998). It must have been connected to the Fennoscandian Ice Sheet during the Last Glacial Maximum (Hughes et al., 2016; Landvik et al., 1998; Svendsen et al., 2004). Woodfjorden and its trough constituted one of the main northern gateways for fast flowing ice streams that drained the northwestern sector of these ice sheets during the Last Glacial Maximum (Hormes et al., 2013; Ottesen et al., 2007). Whereas the Holocene and in part the late Weichselian have been relatively well documented off (south)western Svalbard (Hald et al., 2004; Jernas et al., 2013; Majewski et al., 2009; Rasmussen et al., 2007, 2012; T. L. Rasmussen et al., 2014a; Sarnthein et al., 2003; Skirbekk et al., 2010; Ślubowska-Woldengen et al., 2007; Werner et al., 2011), palaeoceanographic records from northern Svalbard (Chauhan et al., 2014, 2015; Koç et al., 2002; Kubischta et al., 2011; Ślubowska et al., 2005) are still scarce (Fig. 1b). The present study aims to fill this gap by compiling multi-proxy data, in particular, physical properties of the sediment, the faunal distribution and geochemical composition of benthic foraminifera, and biomarkers. Additionally, we generated a high-resolution record of ice-rafted debris (IRD) based on computer tomography. This set of proxies offers the opportunity to reconstruct the influence of AW in surface, intermediate and bottom waters, environmental conditions in surface waters and at the bottom water-sediment interface (including sea ice coverage and primary and export productivity), and glacier activity. Additionally, the study site is located at the transition zone from a glacier-influenced fjord milieu to an open ocean setting; therefore, very sensitive glacier responses to minor changes in oceanic forcing are expected.

\section{Regional setting}

The amount of AW entering the Arctic Ocean is primarily influenced by altering atmospheric pressure gradients and respective circulation patterns, i.e. the North Atlantic Oscillation (NAO) and the Arctic Oscillation (AO). Positive states of the NAO and the AO enhance AW advection, reduce the sea ice coverage and, hence, increase the salinity in the Arctic Ocean, while a negative NAO and AO decrease the AW inflow but foster the sea ice cover and the freshwater content (Rudels, 2009). AW is transported towards the Arctic Ocean by the West Spitsbergen Current (WSC; Fig. 1b). This current follows the western shelf break of the Barents Sea (the core of the WSC mainly appears between the 300 and $1000 \mathrm{~m}$ isobaths; e.g. Saloranta and Svendsen, 2001), continuing northward into the eastern Fram Strait (Rudels, 2009) where 

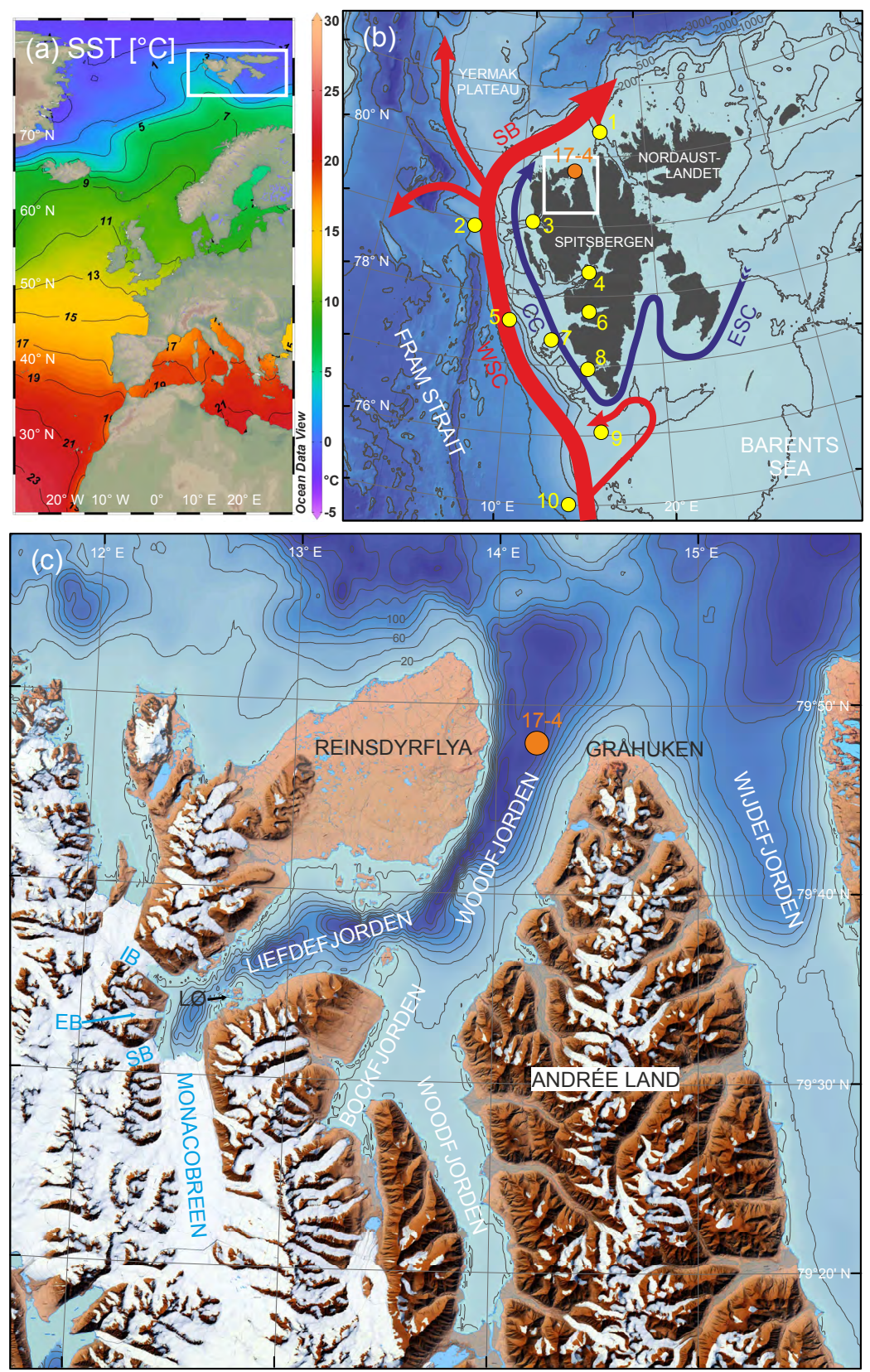

Figure 1. (a) Average annual (1955-2012) sea surface temperatures (SSTs) of the North Atlantic (World Ocean Atlas/Ocean Data View; Locarnini et al., 2013; Schlitzer, 2015). White rectangle: Svalbard area as shown in (b). (b) Main ocean currents in the Svalbard area. Red arrows: Atlantic Water (WSC: West Spitsbergen Current; SB: Svalbard Branch). Blue arrows: Arctic Water (ESC: East Spitsbergen Current; CC: coastal current). The orange dot marks the study location (GeoB10817-4). Yellow dots mark other core sites mentioned in the text: 1. NP94-51 (Jernas et al., 2013; Koç et al., 2002; Ślubowska-Woldengen et al., 2007; Ślubowska et al., 2005); 2. MSM5/5-712-1 (Müller et al., 2012; Spielhagen et al., 2011; Werner et al., 2011, 2013, 2014); 3. NP05-11-21 (Jernas et al., 2013; T. L. Rasmussen et al., 2014a; Skirbekk et al., 2010); 4. JM98-845 (Rasmussen et al., 2012); 5. MD99-2304 (Hald et al., 2004); 6. MD99-2305 (Hald et al., 2004); 7. JM02440 (Ślubowska-Woldengen et al., 2007); 8. HR3 (Majewski et al., 2009); 9. JM02-460 (Rasmussen et al., 2007); 10. 23258 (Sarnthein et al., 2003). White rectangle: study area as shown in (c). (c) Woodfjorden area with eponymous fjord and adjacent fjords. EB: Emmabreen; IB: Idabreen; SB: Seligerbreen; LØ: Lernerøyane. The orange dot marks the study location (GeoB10817-4). The bathymetric metadata and digital terrain model data products in (b) and (c) were derived from the EMODnet Bathymetry portal (http://emodnet-bathymetry.eu/). Topographic data in (c): CNorwegian Polar Institute (2014). 
it sinks and flows below a colder and fresher surface water mass around $78^{\circ} \mathrm{N}$ (Johannessen, 1986; Manley, 1995). Therefore, heat loss to the atmosphere decreases as the warm AW core deepens (Beszczynska-Möller et al., 2011; Walczowski, 2013). Subsequently, the current is divided when a branch recirculates westward into the Fram Strait between 78 and $80^{\circ} \mathrm{N}$ (e.g. Hattermann et al., 2016; Schauer et al., 2004; Fig. 1b), merging with the cold and relatively fresh East Greenland Current that flows southward along the continental shelf of East Greenland (Rudels, 2009). At the northwestern shelf break of Spitsbergen, the WSC is separated into two branches that enter the Arctic Ocean (Fig. 1b). One branch circuits around the Yermak Plateau along its western slope flowing eastward into the Arctic Ocean (Yermak Branch). The second branch, namely the Svalbard Branch, crosses the southern Yermak Plateau and follows the northern shelf of Svalbard (Aagaard et al., 1987). Although the volume transport of the Svalbard Branch is smaller than that of the Yermak Branch $(\sim 1.8$ and $\sim 4.9 \mathrm{~Sv}$ (sverdrup), respectively; $1 \mathrm{~Sv}=10^{6} \mathrm{~m}^{3} \mathrm{~s}^{-1}$; Beszczynska-Möller et al., 2012), the former transports slightly warmer water than the latter (Beszczynska-Möller et al., 2012; Schauer et al., 2004). Therefore, the Svalbard Branch is considered as the most important route for warm, saline AW into the Arctic Ocean (Manley, 1995; Saloranta and Haugan, 2001). The volume transport of the WSC differs seasonally, with highest values in winter and lowest in summer (Beszczynska-Möller et al., 2012). Additionally, the current is less stratified in winter, caused by cooling in the Nordic Seas and current velocities are higher due to stronger wind forcing compared to the summer situation (von Appen et al., 2016). Atlantic-derived waters advected by the WSC are divided from colder and fresher Arctic waters (i.e. transported by the northern extension of the East Spitsbergen Current; Fig. 1b; Loeng, 1991; Skogseth et al., 2005) by the Arctic (Coastal) Front on the western and northern shelves of Svalbard (Walczowski, 2013). Thus, AW is only able to enter Svalbard's shelf and fjords when surmounting this front. Barotropic instabilities seem to be the major mechanisms allowing AW to cross this temperaturesalinity front (Cottier et al., 2005; Saloranta and Svendsen, 2001; Teigen et al., 2010). Especially during winter, windinduced upwelling also significantly promotes $\mathrm{AW}$ advection across the Arctic (Coastal) Front (Cottier et al., 2005, 2007). In Woodfjorden, inflowing Atlantic-derived waters are stratified during summer - framed by a fresher surface water layer and a deeper colder water mass resulting from fall to winter vertical mixing processes (see illustrations of seasonal water mass distributions in a "typical" Svalbard fjord in Cottier et al., 2010), as illustrated by hydrographic data obtained during cruise MSM02/03 with RV Maria S. Merian in August 2006 (Fig. 2).

The Woodfjorden system in northern Spitsbergen, the main island of the Svalbard Archipelago, includes the eponymous main fjord and the two tributary fjords Bockfjorden and Liefdefjorden (Fig. 1c). At present, only the latter is fed

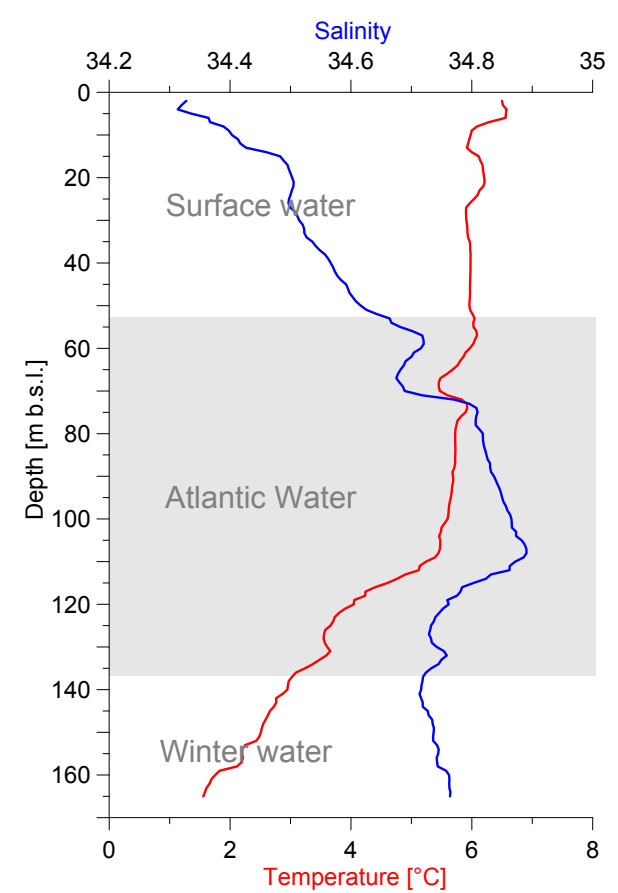

Figure 2. Temperature and salinity against depth (in metres below sea level, m b.s.l.) at station MSM02/03-666-3 (same location as the studied sediment core GeoB10817-4; see Sect. 3) derived during cruise MSM02/03 applying a Sea-Bird CTD sensor as described in the cruise report (Lherminier et al., 2009). The profile illustrates subsurface Atlantic Water inflow at the core site (grey shading), framed by less saline surface water on top and colder winter water at the bottom. Winter water forms locally by convection processes during autumn-winter (Cottier et al., 2010). Temperature $\left(>3{ }^{\circ} \mathrm{C}\right)$ and salinity boundaries ( $>34.65)$ following Cottier et al. (2005).

by four tidewater glaciers: Monacobreen and Seligerbreen (breen means "glacier" in Norwegian), which form one joint glacier front, and the two smaller glaciers Emmabreen and Idabreen (Fig. 1c). Monacobreen is the 10th largest outlet glacier on Svalbard (Hagen et al., 1993). Meltwater from these glaciers contributes to the cold, relatively low-salinity surface water layer in the fjord (Fig. 2). Today, almost $60 \%$ of Svalbard's landmasses are glaciated (Hagen et al., 1993; Kohler et al., 2007). This almost $34,000 \mathrm{~km}^{2}$ of glaciers and ice caps represents $4.6 \%$ of all glaciated areas on Earth (Radić et al., 2014). Calving of Svalbard's tidewater glaciers causes a total mass loss of $5.0-8.4 \mathrm{~km}^{3} \mathrm{yr}^{-1}$ contributing $\sim 2 \%\left(0.02 \mathrm{~mm} \mathrm{yr}^{-1}\right)$ to the annual global sea level rise (Błaszczyk et al., 2009).

\section{Material and methods}

The $275 \mathrm{~cm}$ long sediment core GeoB10817-4 used in this study was retrieved at the mouth of Woodfjorden (N Spitsbergen; $79.80^{\circ} \mathrm{N}, 14.20^{\circ} \mathrm{E}$; water depth $171 \mathrm{~m}$; Fig. 1c) during cruise MSM02/03 in 2006 (Lherminier et al., 2009). Work- 


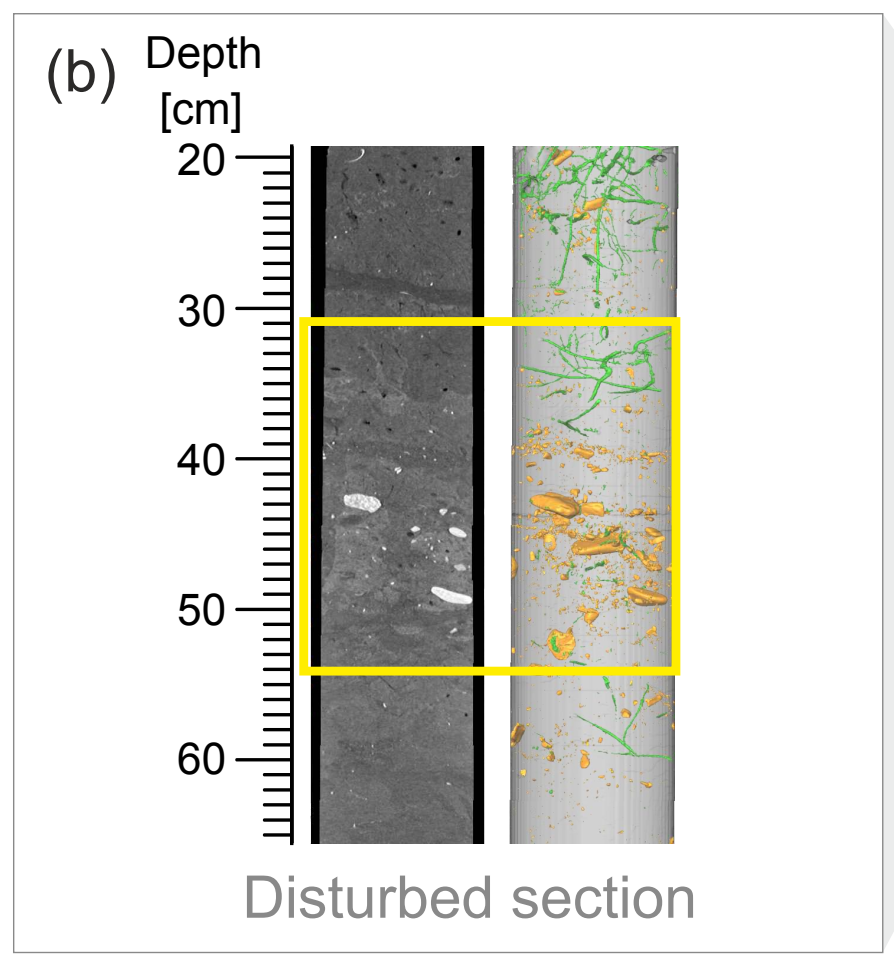

(a)

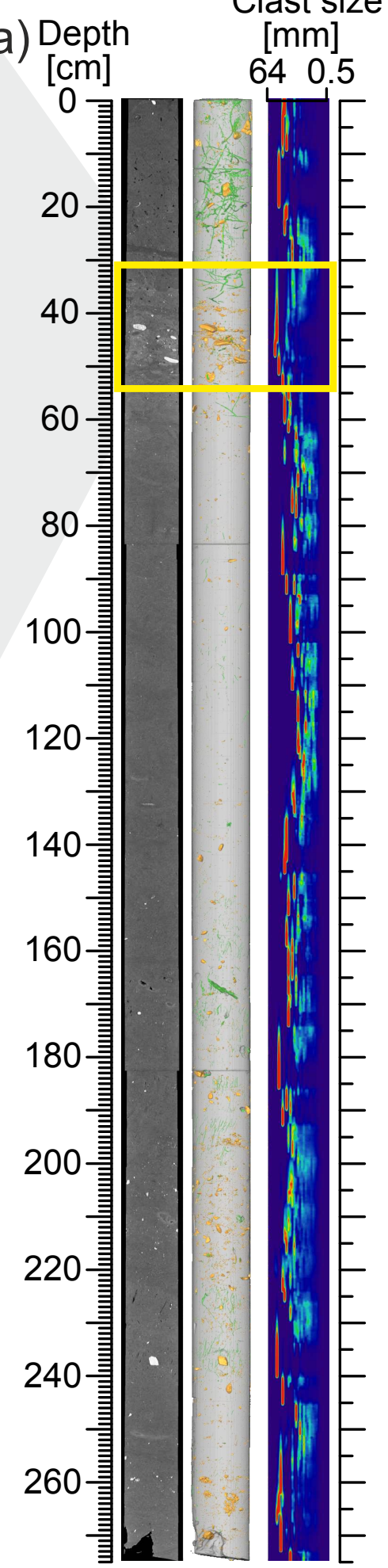

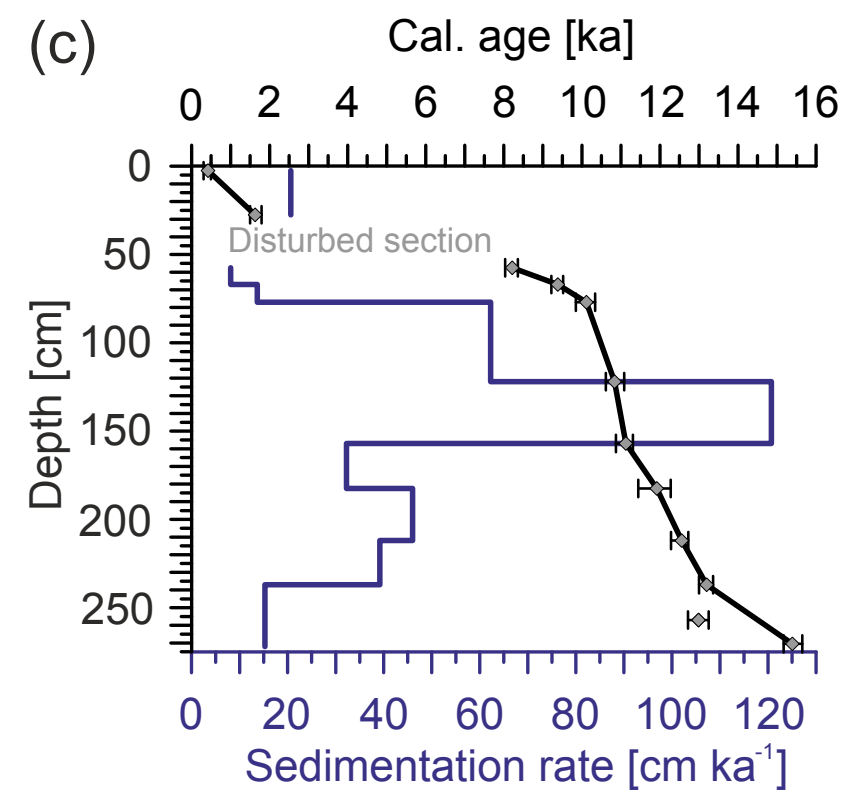

Figure 3. (a) CT scan of the core GeoB10817-4. Left to right: orthogonal profile; interpreted image (clasts and bioturbation; see legend); clast size distribution (0-20 vol.\% of clasts: blue to red, respectively). The yellow rectangle marks the disturbed section also shown in (b). (b) CT images (orthogonal and interpreted) of the disturbed section (yellow rectangle; definition of boundaries; see Sect. 4.1 and Fig. A2 in the Appendix). (c) Age-depth plot for sediment core GeoB10817-4: the diamonds show calibrated (median) ages with error bars (Table 1); the solid black line shows linear interpolation excluding an outlier at $257 \mathrm{~cm}$. The blue solid line shows corresponding sedimentation rates. 
Table 1. AMS radiocarbon measurements and calibrated ages applying the Marine13 calibration curve (Reimer et al., 2013) and an averaged regional $\Delta R=98 \pm 37$ years (calib.qub.ac.uk). All measurements, apart from the measurements at 2.5 and $270.5 \mathrm{~cm}$ (CologneAMS, University of Cologne), were carried out at ETH Zürich. Median ages (in bold) were used for the age-depth model.

\begin{tabular}{|c|c|c|c|c|c|c|c|}
\hline \multirow[t]{2}{*}{ Lab ID } & \multirow{2}{*}{$\begin{array}{r}\text { Depth } \\
{[\mathrm{cm}]}\end{array}$} & \multirow[t]{2}{*}{ Dated material } & \multicolumn{2}{|c|}{${ }^{14} \mathrm{C}$ age } & \multicolumn{3}{|c|}{ Cal. age $(2 \sigma)[\mathrm{a}]$} \\
\hline & & & [a] & \pm & Min & $\operatorname{Max}$ & Median \\
\hline COL2571.1.1 & 2.5 & Mixed benthic foraminifera & 879 & 31 & 307 & 496 & 420 \\
\hline ЕTH-58439 & 27.5 & Mixed benthic foraminifera & 2155 & 45 & 1499 & 1795 & 1630 \\
\hline ETH-61277 & 57.5 & N. labradorica & 7845 & 65 & 8035 & 8360 & 8216 \\
\hline ETH-64606 & 67 & N. labradorica & 8815 & 60 & 9217 & 9519 & 9384 \\
\hline ETH-61278 & 77 & N. labradorica & 9395 & 75 & 9846 & 10339 & 10114 \\
\hline ETH-61279 & 122 & N. labradorica & 9980 & 75 & 10613 & 11082 & 10837 \\
\hline ETH-61280 & 157 & N. labradorica & 10230 & 75 & 10873 & 11306 & 11127 \\
\hline ETH-58440 & 182.5 & Mixed benthic foraminifera & 10710 & 70 & 11445 & 12276 & 11918 \\
\hline ETH-64607 & 212 & N. labradorica & 11120 & 80 & 12283 & 12726 & 12559 \\
\hline ETH-58441 & 237 & Mixed benthic foraminifera & 11810 & 70 & 13000 & 13363 & 13197 \\
\hline ETH-64608 & 257 & Mixed benthic foraminifera & $11610^{*}$ & 120 & \multicolumn{3}{|c|}{ Age reversal } \\
\hline COL2572.1.1 & 270.5 & Mixed benthic foraminifera & 13391 & 53 & 15167 & 15648 & 15391 \\
\hline
\end{tabular}

* The radiocarbon age from $257 \mathrm{~cm}$ was excluded from the age-depth model (as discussed in Sect. 4.2).

ing halves were sampled with $10 \mathrm{~mL}$ syringes for microfossil analyses and grain size measurements at $5 \mathrm{~cm}$ intervals as well as for biomarker analyses at a lower resolution at selected depths.

\subsection{Computer tomography}

Archive halves of the sediment core GeoB10817-4 were scanned using a Toshiba Aquilion $64^{\mathrm{TM}}$ computer tomograph (CT) at the hospital Klinikum Bremen-Mitte, with an Xray source voltage of $120 \mathrm{kV}$ and a current of $600 \mathrm{~mA}$. The CT image stacks have a resolution of $0.35 \mathrm{~mm}$ in the $x$ and $y$ directions and $0.5 \mathrm{~mm}$ resolution in the $z$ direction $(0.3 \mathrm{~mm}$ reconstruction unit). Images were reconstructed using Toshiba's patented helical cone beam reconstruction technique. The CT data obtained were processed using the ZIB edition of the Amira software (version 2016.25; Stalling et al., 2005). Within Amira, the CT scans of the core sections were merged and core liners, including about $2 \mathrm{~mm}$ of the core rims, were removed from the data set. All clasts $>\sim 1 \mathrm{~mm}$ and bioturbation traces were quantified in each reconstruction slice with the "Segmentation Editor" (threshold segmentation) and the "Material Statistics" module. The threshold values used were $>1500$ for lithic clasts, 6011499 for matrix sediment, 1-600 for bioturbation traces (open voids within the sediment that were filled by air and/or water were included), and $<1$ for the surrounding air and water. With the "Connected Components" module, the individual clasts were separated and subsequently analysed with the "Shape Analysis" module for their parameterization. The determined clast length was further used for a clast size analysis. Therefore, every clast within an interval of $167 \mathrm{CT}$ slices (corresponding to a $\sim 5 \mathrm{~cm}$ core interval) was considered and the obtained result was written to the depth of the central slice position. The analysing interval was moved slice by slice. The final results (unit: vol. \% of all segmented clasts) were exported in a spreadsheet. Additionally, the X-ray density of the matrix sediment was evaluated by calculating the mean value and its standard deviation of the matrix sediment per slice (measured in Hounsfield units (HU); the matrix sediment segmentation was reduced by two voxels to exclude potential marginal artefacts).

\subsection{AMS radiocarbon measurements}

The chronostratigraphy of core GeoB10817-4 is based on 11 accelerator mass spectrometry (AMS) radiocarbon measurements from either mixed benthic foraminifera or $N$. labradorica tests, achieved at the CologneAMS facility of the University of Cologne or at the ETH of Zürich, respectively (Table 1). Radiocarbon ages were converted into calibrated years before present (before 1950 CE) using the radiocarbon calibration software CALIB 7.1 (calib.qub.ac. uk/calib/) and the Marine13 calibration curve (Reimer et al., 2013). Reservoir ages may have changed in the past, especially at high northern latitudes as well as during the Younger Dryas (YD) and during Heinrich Stadial 1 (e.g. Austin et al., 1995, 2011; Bard et al., 1994; Hanslik et al., 2010; Waelbroeck et al., 2001). However, as no information about palaeo-reservoir ages is available for the Svalbard area (see also Ślubowska-Woldengen et al., 2007), we applied an averaged regional reservoir age correction $(\Delta R=98 \pm 37$ years), based on six $\Delta \mathrm{R}$ values from the Svalbard region (Mangerud, 1972; Mangerud and Gulliksen, 1975; Olsson, 1980) derived from the Marine Reservoir Correction Database (calib.qub. ac.uk/marine/). 


\subsection{Grain size measurements}

Grain size measurements were performed in the Grain Size Lab at MARUM, University of Bremen, with a Beckman Coulter laser diffraction particle size analyser LS $13320^{\mathrm{TM}}$. Prior to these measurements, the terrigenous sediment fractions were isolated by removing organic carbon, calcium carbonate and biogenic opal by boiling the samples (in about $200 \mathrm{~mL}$ water) with $10 \mathrm{~mL}$ of $\mathrm{H}_{2} \mathrm{O}_{2}(35 \%$; until the reaction stopped), $10 \mathrm{~mL}$ of $\mathrm{HCl}(10 \% ; 1 \mathrm{~min})$ and $6 \mathrm{~g}$ of $\mathrm{NaOH}$ pellets $(10 \mathrm{~min})$, respectively. After each step the samples were diluted (dilution factor: $>25$ ). Finally, remaining aggregates were destroyed prior to the measurements by boiling the samples with $\sim 0.3 \mathrm{~g}$ of tetrasodium diphosphate decahydrate $\left(\mathrm{Na}_{4} \mathrm{P}_{2} \mathrm{O}_{7} * 10 \mathrm{H}_{2} \mathrm{O} ; 3 \mathrm{~min}\right.$; see McGregor et al., 2009). Sample preparation and measurements were carried out with deionized, degassed and filtered water (filter mesh size: $0.2 \mu \mathrm{m}$ ) to reduce the potential influence of gas bubbles or particles within the water. Results consist of grain size distributions within a 0.04 to $2000 \mu \mathrm{m}$ range, divided into 116 size classes. The calculation of the grain sizes relies on the Fraunhofer diffraction theory and the polarization intensity differential scattering (PIDS) for particles from 0.4 to $2000 \mu \mathrm{m}$ and from 0.04 to $0.4 \mu \mathrm{m}$, respectively. Reproducibility is checked regularly through replicate analyses of three internal glass-bead standards. It is better than $\pm 0.7 \mu \mathrm{m}$ for the mean and $\pm 0.6 \mu \mathrm{m}$ for the median grain size $(1 \sigma)$. The average standard deviation integrated over all size classes is better than \pm 4 vol. \% (note that the standard deviation of the individual size classes is not distributed uniformly). All provided statistic values are based on geometric statistics.

Sediment grains larger than $310 \mu \mathrm{m}$ have not been detected by the laser diffraction particle size analyser, although coarser sand particles and even gravels are detected within the sieved samples of the microfossil analysis as well as within the CT clast size analyses (see Sects. 3.4 and 4.1; Fig. 3a). This bias results from the very small sample volume $(\sim 0.5 \mathrm{~mL})$ for the particle size analysis. However, taking into account that $>98 \mathrm{wt}$. \% of the dried bulk sediment is $<150 \mu \mathrm{m}$ (with the exception of four samples with 3, 4, 6 and 12 wt. $\%>150 \mu \mathrm{m}$ fraction; Bartels, unpublished data), the observed grain size patterns of the siliciclastic fraction are considered as reliable.

\subsection{Microfossil analyses}

Bulk sediment samples were washed through a $63 \mu \mathrm{m}$ sieve. The coarse fraction was dried and sieved through $100 \mu \mathrm{m}$ and $150 \mu \mathrm{m}$ meshes. Faunal analyses were carried out on two fractions: $100-150 \mu \mathrm{m}$ and $>150 \mu \mathrm{m}$ (Fig. A1 in the Appendix). Counts from both fractions were summed up (i.e. $>100 \mu \mathrm{m}$ ) for the discussion below. Samples with high numbers of foraminifera were split with a microsplitter. Wherever possible, 200-300 benthic foraminifera were counted in each fraction of every sample to obtain statistically ro- bust results (Murray, 2006; Patterson and Fishbein, 1989). In addition, three replicates of an un-split sample as well as of a split sample were counted (each split was counted four times, including the initially counted sample). Statistical calculations reveal a standard error of 3.52 and $2.95 \%$, respectively. Most benthic foraminifera were identified to species level, except for agglutinants, which were mainly identified to genera level due to their poorer preservation. The majority of calcareous benthic foraminifera are well preserved, but several specimens show indications of dissolution or transport. Small fragments were not counted since these specimens might be allochthonous. Distinct Stainforthia and Buccella morphotypes were lumped together as Stainforthia loeblichi s.l. and Buccella frigida s.l., respectively, because in each case possibly two species (S. loeblichi s.s. and S. concava as well as B. frigida s.s. and B. tenerrima, respectively) could not be distinguished definitely. Hyaline and agglutinating species that could not be identified are summarized as Rotaliina and Textulariina, respectively. Only a few planktonic foraminifera were present in the material. As postmortem degradation might be the main reason for the distribution of arenaceous taxa (Murray, 2006), percentages of calcareous benthic species were calculated excluding agglutinants to avoid these taphonomic effects.

Accumulation rates of benthic foraminifera were calculated following the equation of Ehrmann and Thiede (1985):

$\mathrm{ARBF}=\mathrm{LSR} \cdot \rho \cdot \mathrm{BFN}$,

where ARBF is the accumulation rate of benthic foraminifera [individuals $\mathrm{cm}^{-2} \mathrm{ka}^{-1}$ ], LSR the linear sedimentation rate $\left[\mathrm{cm} \mathrm{ka}^{-1}\right], \rho$ the density of dry sediment $\left[\mathrm{g} \mathrm{cm}^{-3}\right]$ and BFN the benthic foraminifera number (per gram dry sediment) [individuals $\mathrm{g}^{-1}$ ].

\subsection{Stable isotope measurements}

Stable carbon and oxygen isotopes were measured at ZMT (Leibniz Centre for Tropical Marine Ecology) in Bremen, using a Finnigan MAT $253^{\mathrm{TM}}$ gas isotope ratio mass spectrometer with a Kiel IV automated carbonate preparation device (standard deviations of house standard: $0.02 \%$ for $\delta^{13} \mathrm{C}$ and $0.06 \%$ for $\delta^{18} \mathrm{O}$ ), and at MARUM (Bremen), using a Finnigan MAT $251^{\mathrm{TM}}$ mass spectrometer with a Kiel I carbonate preparation device (standard deviations of house standard: $0.02 \%$ or $\delta^{13} \mathrm{C}$ and $0.03 \%$ for $\delta^{18} \mathrm{O}$ ). The measurements were performed on two to eight tests (test size: 150 $500 \mu \mathrm{m})$ of the epibenthic foraminifera Cibicides lobatulus (Ahrens et al., 1997; Dubicka et al., 2015) and the endobenthic foraminifera Nonionellina labradorica (Ahrens et al., 1997; Alve and Bernhard, 1995; Loubere and Rayray, 2016) for bottom water and pore water signals, respectively. Stable oxygen isotope values were corrected for a global ice volume effect (Waelbroeck et al., 2002) and adjusted for vital effects: $+0.64 \%$ o for C. lobatulus (Shackleton, 1974) and $-0.2 \%$ o for $N$. labradorica (Duplessy et al., 2005). 


\subsection{Biomarker analyses}

Selected dried sediment samples were homogenized and used for geochemical analyses. For the determination of the total organic carbon (TOC) content using an ELTRA ${ }^{\mathrm{TM}}$ analyser, $100 \mu \mathrm{g}$ of sediment was used. Alkenone analyses, carried out to reconstruct sea surface temperatures (SSTs), were extracted using $2 \mathrm{~g}$ of sediment with an accelerated solvent extractor (DIONEX ${ }^{\mathrm{TM}}$, ASE $200 ; 100^{\circ} \mathrm{C}, 1000 \mathrm{psi}$, $15 \mathrm{~min}$, dichloromethane and methanol $(99: 1, v / v)$ as solvent). The separation of compounds was carried out using open column chromatography $\left(\mathrm{SiO}_{2}\right)$ using $n$-hexane, dichloromethane $(1: 1, v / v)$ and dichloromethane. The composition of alkenones was analysed using gas chromatography (Agilent ${ }^{\mathrm{TM}}$ 7890). Individual alkenone $\left(\mathrm{C}_{37: 4}, \mathrm{C}_{37: 3}\right.$, $\mathrm{C}_{37: 2}$ ) identification is based on retention time and the comparison with an external standard.

The alkenone unsaturation index $\left(U_{37}^{K}\right)$ as proxy for SST $\left[{ }^{\circ} \mathrm{C}\right]$ was calculated following Brassell et al. (1986) due to the presence of the $\mathrm{C}_{37: 4}$ alkenone. For calculating SST, the equation

$U_{37}^{K^{\prime}}=0.033 \cdot T\left[{ }^{\circ} \mathrm{C}\right]+0.044$

by Müller et al. (1998) - based on a global core-top calibration $\left(60^{\circ} \mathrm{N}-60^{\circ} \mathrm{S}\right)$ - was used (replacing $U_{37}^{K^{\prime}}$ using $U_{37}^{K}$ due to the presence of the $\mathrm{C}_{37: 4}$ alkenones). This equation (Eq. 2) yielded more realistic results compared to other equations whose temperature reconstructions were much too high (e.g. Prahl and Wakeham, 1987). The standard error of the calibration is reported as $\pm 1.5^{\circ} \mathrm{C}$. The instrument stability was continuously controlled using re-runs of an external alkenone standard (extracted from Emiliania huxleyi cultures with a known growth temperature) during the analytical sequences. The range of the total analytical error calculated using replicate analyses is less than $0.4^{\circ} \mathrm{C}$.

The $\mathrm{C}_{25}$ isoprenoid lipid biomarker $\left(\mathrm{IP}_{25}\right)$ was analysed to document sea ice coverage (Belt et al., 2007). Brassicasterol and dinosterol have been used as phytoplankton biomarkers (see Fahl and Stein, 1999; Volkman, 1986; Volkman et al., 1993). For extraction of $\mathrm{IP}_{25}$ and sterols, $3 \mathrm{~g}$ of sediment was ultrasonicated (Sonorex Super RK 510, $35 \mathrm{Khz}, 15 \mathrm{~min})$ using dichloromethane:methanol (2: $1, v / v)$ as solvent. For quantification, internal standards 7-hexylnonadecane (7-HND, $0.076 \mu \mathrm{g}$ per sample for $\mathrm{IP}_{25}$ quantification), squalane (2.4 $\mu$ g per sample) and cholest5 -en-3 $\beta$-ol-D 6 (10 $\mu$ g per sample for sterol quantification) were added prior to analytical treatment. Separation of the hydrocarbon and sterol fractions was carried out via open column chromatography (hydrocarbon fraction with $5 \mathrm{~mL} n$ hexane, the sterol fraction with $6 \mathrm{~mL} n$-hexane:ethylacetate $(5: 1, v / v))$. The latter fraction was silylated with $500 \mathrm{~mL}$ BSTFA (bis-trimethylsilyl-trifluoroacet-amide) $\left(60^{\circ} \mathrm{C}, 2 \mathrm{~h}\right)$. $\mathrm{IP}_{25}$ and sterols were analysed using gas chromatography and mass spectrometry. Component assignment was based on comparison of gas chromatography retention times with those of reference compounds and published mass spectra. The Kovats index calculated for $\mathrm{IP}_{25}$ is 2086. The detection limit for quantification of $\mathrm{IP}_{25}$ (Agilent 7890B $\mathrm{GC}^{\mathrm{TM}}$, Agilent $5977 \mathrm{~A}^{\mathrm{TM}}$ Extractor MSD with performance turbo pump) is $0.005 \mathrm{ng} \mu \mathrm{L}^{-1}$ in SIM (selected ion monitoring) mode. The retention indices for brassicasterol (as 24methylcholesta-5,22E-dien-3 $\beta$-O-Si $\left.\left(\mathrm{CH}_{3}\right)_{3}\right)$ and dinosterol (as $4 \alpha, 23,24$-trimethyl- $5 \alpha$-cholest-22E-en- $3 \beta$-O-Si $\left(\mathrm{CH}_{3}\right)_{3}$ ) were calculated to be 1.018 and 1.091 (normalized to cholest5 -en-3 $\beta$-ol-D 6 set to be 1.000 ), respectively.

For the quantification of $\mathrm{IP}_{25}$, its molecular ion $(\mathrm{m} / z$ 350) in relation to the abundant fragment ion $m / z 266$ of the internal standard (7-HND) was used (SIM mode). The different responses of these ions were balanced using an external calibration (Fahl and Stein, 2012). Brassicasterol and dinosterol were quantified as trimethylsilyl ethers using the molecular ions $m / z 470$ and $m / z 500$, respectively, in relation to the molecular ion $m / z 464$ of cholesterol- $\mathrm{D}_{6}$. For more details about the quantification of $\mathrm{IP}_{25}$ as well as the sterols, see Fahl and Stein (2012). Accumulation rates of sea ice and phytoplankton biomarkers ( $\mathrm{IP}_{25}$ and brassicasterol, respectively) were calculated following Eq. (1) by replacing the BFN term accordingly.

For more semi-quantitative estimates of present and past sea ice coverage, Müller et al. (2011) combined the sea ice proxy $\mathrm{IP}_{25}$ and phytoplankton biomarkers in a phytoplankton-IP 25 index, the so-called $\mathrm{PIP}_{25}$ index:

$\mathrm{PIP}_{25}=\frac{\left[\mathrm{IP}_{25}\right]}{\left[\mathrm{IP}_{25}\right]+([\text { phytoplankton marker }] \cdot \mathrm{c})}$,

with c equal to the mean $\mathrm{IP}_{25}$ concentration divided by the mean phytoplankton biomarker concentration.

As phytoplankton biomarker, brassicasterol was used (for further discussion of advantages and limitations of the $\mathrm{PIP}_{25}$ approach see Belt and Müller, 2013; Smik et al., 2016; Stein et al., 2012; Xiao et al., 2015). Following the classification scheme of Müller et al. (2011), PIP $_{25}$ values between 0.3 and 0.5 , between 0.5 and 0.7 , and $\gg 0.7$ point to a reduced sea ice cover, a seasonal sea ice cover including an ice edge situation and an extended to perennial sea ice cover, respectively.

\section{Results}

\subsection{Core description}

The sediment of core GeoB10817-4 consists of some coarse sand and gravel, with scattered pebbles (Fig. 3a) embedded in a homogeneous silty clay matrix sediment. The upper $\sim 30 \mathrm{~cm}$ of the sediment core are heavily bioturbated, as illustrated by the CT scan. The interval between 31 and $54 \mathrm{~cm}$ is characterized by a basal erosional unconformity, weakly visible on the CT picture (Fig. 3b), and high amounts of (extra- and intra-)clasts (Fig. 3b), sand (including high quantities of foraminiferal tests) and bivalve shell fragments. 


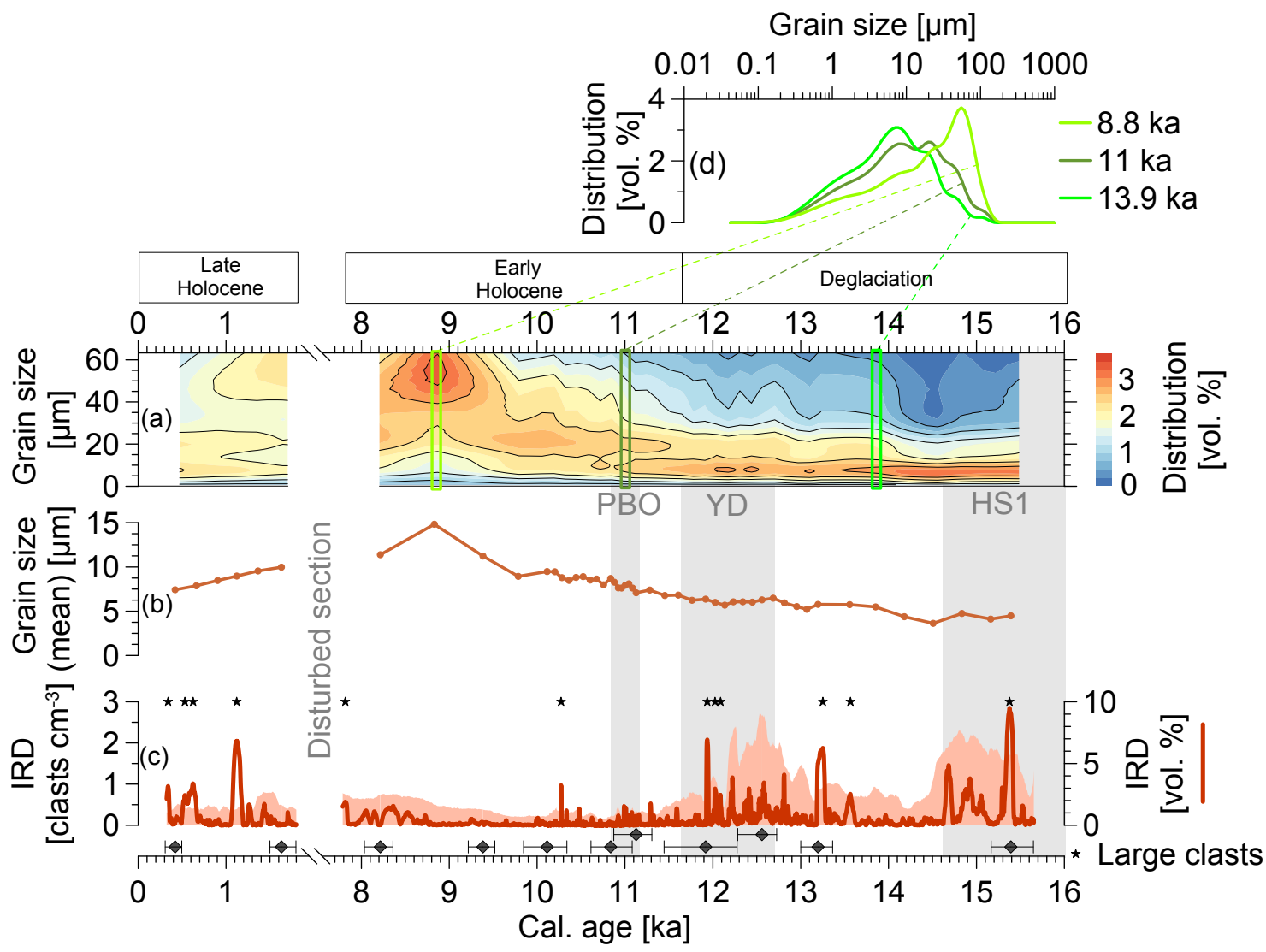

Figure 4. (a) Grain size distribution [vol.\%] of fine siliciclastic sediments (0-63 $\mu \mathrm{m})$ derived from laser diffraction particle size analyses. Green rectangles: selected grain size distributions as shown in (d). (b) Mean grain size $[\mu \mathrm{m}]$ of siliciclastic sediments. (c) Ice-rafted debris (IRD): volume percentage (solid red line) and clasts per cubic centimetre (reddish shading) derived from CT analysis. Stars mark peaks in vol. \% corresponding to single large clasts. Grey vertical shadings indicate cold periods: Preboreal Oscillation (PBO), Younger Dryas (YD) and Heinrich Stadial 1 (HS1). Dark grey diamonds: calibrated radiocarbon dated depths with error ranges. (d) Selected grain size distributions [vol.\%] at $\sim 8.8 \mathrm{ka}$ (light green line), $\sim 11 \mathrm{ka}$ (dark green line) and $\sim 13.9 \mathrm{ka}$ (green line).

Furthermore, the interval exhibits an increasing X-ray density with an enhanced standard deviation accompanied by a coarsening upward of the siliciclastic fine fraction $(<63 \mu \mathrm{m}$; observed in the grain size analyses; Fig. A2 in the Appendix). These sedimentological features point to an allochthonous origin and a deposition by mass wasting. Consequently, this interval is excluded from the subsequent palaeoceanographic reconstructions. Below this disturbance and as deep as $140 \mathrm{~cm}$, a small number of clasts are found, whereas the lower part of the core contains high amounts of coarse debris (Fig. 3a).

\subsection{Chronology}

Assuming linear sedimentation rates between dated depths (ranging between 8 and $121 \mathrm{~cm} \mathrm{ka}^{-1}$ ), calibrated ages have been interpolated (Fig. 3c; Table 1). The segment below the $31-54 \mathrm{~cm}$ interval (Sect. 4.1 ) covers a time span from $\sim 15.7$ to $7.8 \mathrm{cal}$. ka, whereas the one above ranges from $\sim 1.8$ to $0.3 \mathrm{cal} . \mathrm{ka}$ (from here on, all ages are given as calibrated ages and data are presented exclusively against age). This indicates that the deposition of the $31-54 \mathrm{~cm}$ layer led to a $\sim 6000$-year gap in the sequence, spanning a large part of the Holocene. The radiocarbon age at $257 \mathrm{~cm}$ depth has been excluded from the age model because it was obtained from a much smaller sample ( $\sim 0.4 \mathrm{mg}$ carbonate) than the overlying $237 \mathrm{~cm}$ deep older sample $(\sim 4.3 \mathrm{mg})$ that has been measured four times with consistent results.

\subsection{Sedimentology}

\subsubsection{Grain sizes}

Until $\sim 13 \mathrm{ka}$, the grain size distribution of siliciclastic sediments reached a maximum of about $7 \mu \mathrm{m}$ (mean: 4-6 $\mu \mathrm{m}$ ). In the subsequent period until $\sim 11.1 \mathrm{ka}$, a slight coarsening (max. at $\sim 8-9 \mu \mathrm{m}$, mean: $6-7 \mu \mathrm{m}$ ) is observed. A further shift to coarser silt (max. at $\sim 20 \mu \mathrm{m}$, mean: $8-9 \mu \mathrm{m}$ ) appeared around $10.8 \mathrm{ka}$. From $\sim 9.4 \mathrm{ka}$ on, silt around 45 $50 \mu \mathrm{m}$ shows the highest percentages (mean: $11-15 \mu \mathrm{m}$ ). In 
the uppermost interval of the core $(\sim 1.6-0.4 \mathrm{ka})$, a trend back to finer sediments (mean: $7-10 \mu \mathrm{m}$ ) is evident, but with a more even distribution than below the disturbed section (Fig. 4a, b).

\subsubsection{Ice-rafted debris}

Clasts $>\sim 1 \mathrm{~mm}$ detected using CT analyses (Sect. 3.1) were considered as IRD. The interpretation of the IRD abundances is based on the volume percentages and number of clasts observed on CT scans, as the combination of these data depicts the best available IRD distribution (Figs. 3a, 4c): only a consideration of volume percentages would overestimate large clasts while the number of clasts alone would overestimate the significance of small debris. For comparison, accumulation rates of counted clasts $(>500 \mu \mathrm{m}$; based on Ehrmann and Thiede, 1985) from sieved syringe samples are shown in the Appendix (Fig. A3) illustrating that the CTbased data offer a much more precise IRD record. CT data show that IRD is more abundant at the core bottom, containing high quantities prior to $\sim 14.5 \mathrm{ka}$ (up to 10 vol. $\%$; up to 2.3 clasts $\mathrm{cm}^{-3}$ ), but decrease afterwards (down to $0 \%$ and 0.4 clasts $\mathrm{cm}^{-3}$ ). From $\sim 13.1 \mathrm{ka}$ on, IRD amounts rise again until $\sim 11.5 \mathrm{ka}\left(\max .7 \%\right.$; $\max .2 .8$ clasts $\mathrm{cm}^{-3}$ ). From then on, the volume percentages and number of clasts illustrate a low but continuous flux of ice-rafted material (mean: $0.2 \% ; 0.3$ clasts $\mathrm{cm}^{-3}$ ), and some increase particularly from $\sim 8.5 \mathrm{ka}$ on (up to $1.9 \%$ and 0.8 clasts $\mathrm{cm}^{-3}$ ). Above the reworked layer (from $\sim 1.8 \mathrm{ka}$ on), a further increase in the IRD content is identified, especially for larger clasts (up to $7 \%$ and 0.8 clasts $\mathrm{cm}^{-3}$; Fig. $4 \mathrm{c}$ ). Some peaks in volume percent reflect single large clasts (marked with a star in Fig. 4c).

\subsection{Microfossil analyses}

\subsubsection{Faunal composition}

Planktic foraminifera were rare or absent. Their percentages range between 0 and $2 \%$ of the total fauna apart from one sample dated $\sim 13 \mathrm{ka}(\sim 5 \%)$. Thus, only benthic species were taken into account for calculations and interpretation. In total, 83 taxa (61 calcareous species) were identified (756 taxa per sample, 7-39 calcareous taxa per sample; Appendix A). Calcareous species represent the major part of the benthic fauna $(\sim 80-100 \%)$; agglutinating species occur mainly in the upper part above the reworked layer (up to $\sim 20 \%$ ) with decreasing percentages down-core (mean: $\sim 2 \%$; Fig. A4a in the Appendix).

\subsubsection{Relative abundance and accumulation rate of benthic foraminifera}

The calcareous fauna is dominated by three species: Cassidulina reniforme $(\sim 18-78 \%$, Fig. 5h), Nonionellina labradorica ( 1-60\%, Fig. 5e) and Elphidium clavatum (formerly named E. excavatum forma clavata; see Darling et al., 2016; 2-46\%, Fig. 5g), accompanied by lower percentages of Buccella frigida s.1. (max. 9\%, Fig. 5c), Cassidulina neoteretis ( $\max . \sim 23 \%$, Fig. 5f), Cibicides lobatulus (max. $\sim 5 \%$, Fig. 5b), Islandiella helenae (max. $\sim 10 \%$, Fig. 5d), Islandiella norcrossi (max. $\sim 8 \%$, Fig. A4g in the Appendix) and Stainforthia loeblichi s.l. (max. $\sim 8 \%$, Fig.A4i in the Appendix).

Until $\sim 12.5 \mathrm{ka}$ the accumulation rate of benthic foraminifera (ARBF) is relatively low (mean value: $\sim 2250$ individuals (ind.) $\mathrm{cm}^{-2} \mathrm{ka}^{-1}$ ) subsequently slightly increasing up to a mean value of $\sim 4770$ ind. $\mathrm{cm}^{-2} \mathrm{ka}^{-1}$. Apart from a few exceptions, the ARBF further rises from $\sim 11.2 \mathrm{ka}$ on (mean value: $\sim 12980$ ind. $\mathrm{cm}^{-2} \mathrm{ka}^{-1}$ ) with peaks at $\sim 10.8, \sim 10.6$ and $\sim 10.1 \mathrm{ka}$ exceeding 30000 ind. $\mathrm{cm}^{-2} \mathrm{ka}^{-1}$ (Fig. 5a). Above the disturbed section (from $\sim 1.6 \mathrm{ka}$ on), the mean $\mathrm{ARBF}$ reaches $\sim 6530$ ind $\mathrm{cm}^{-2} \mathrm{ka}^{-1}$.

\subsection{Geochemistry}

\subsubsection{Stable isotopes}

Stable oxygen isotope values, corrected for vital effects and the global ice volume effect (Sect. 3.5), increase slightly towards core top, with $C$. lobatulus showing more variability and lower values than $N$. labradorica (ranging from 2.5 to $4.1 \%$ and from 3.6 to $4.4 \%$, respectively). Between $\sim 12$ and $\sim 9 \mathrm{ka}, \delta^{18} \mathrm{O}$ values of both species exhibit an enhanced offset (Fig. 6a). Stable carbon isotope values show minor variations for $C$. lobatulus but a slight increase towards core top $\left(0.4\right.$ to $1.6 \%$ ). N. labradorica exhibits depleted $\delta^{13} \mathrm{C}$ values from $\sim 11$ to $\sim 10.1 \mathrm{ka}$ (down to $-2.7 \%$; Fig. $6 \mathrm{~b}$ ). The $\delta^{13} \mathrm{C}$ offset between epi- and endobenthic species $\left(\Delta \delta^{13} \mathrm{C}\right)$ varies between 1.7 and $3.7 \%$, with peak values at $\sim 12.6$, $\sim 10.6, \sim 10.4 \mathrm{ka}$ and $\sim 0.4 \mathrm{ka}$ (Fig. $6 \mathrm{c}$ ).

\subsubsection{Biomarkers}

Alkenone unsaturation index $\left(U_{37}^{K}\right)$ values range from 0.1 to 0.3 . They yield SST values ranging from $\sim 1$ to $\sim 7^{\circ} \mathrm{C}$. The highest temperatures were attained between $\sim 11$ and $\sim 10 \mathrm{ka}$, whereas the lowest values are calculated prior to $\sim 11.9 \mathrm{ka}$ (Fig. 7a).

Accumulation rates of the $\mathrm{C}_{25}$ isoprenoid lipid biomarker $\left(\mathrm{IP}_{25}\right)$ range between $0.8 \mu \mathrm{g} \mathrm{cm}^{-2} \mathrm{ka}^{-1}(\sim 11 \mathrm{ka})$ and almost $0 \mu \mathrm{g} \mathrm{cm}^{-2} \mathrm{ka}^{-1}$ ( 9.4 ka) (Fig. 7c). The phytoplankton-IP 25 index ( $\mathrm{PIP}_{25}$ index) using the phytoplankton biomarker brassicasterol (Müller et al., 2011) exhibits its highest values at $\sim 12.8 \mathrm{ka}(\sim 0.9)$ and its lowest values at $\sim 9.4 \mathrm{ka}(\sim 0.1)$ (Fig. 7b).

The accumulation rates of brassicasterol range between $\sim 1.5 \mu \mathrm{g} \mathrm{cm}^{-2} \mathrm{ka}^{-1}(\sim 14.2 \mathrm{ka})$ and $\sim 167.5 \mu \mathrm{g} \mathrm{cm}^{-2} \mathrm{ka}^{-1}$ ( $\sim 10.9 \mathrm{ka}$ ) (Fig. 7d). The accumulation rate of dinosterol shows an almost parallel trend to that of brassicasterol but values are 1 magnitude lower (Fig. A5 in the Appendix). 


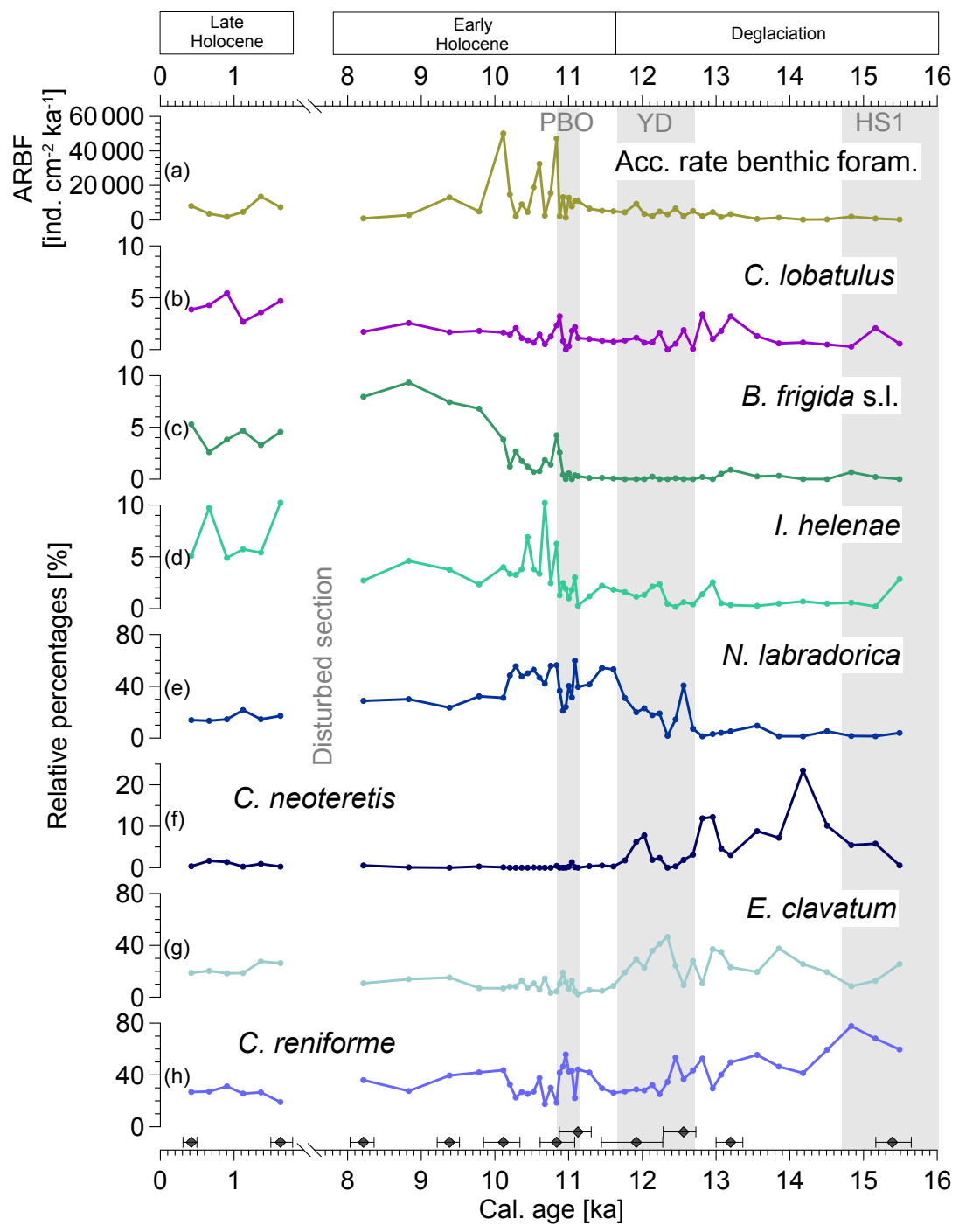

Figure 5. (a) Accumulation rates of benthic foraminifera (ARBFs) and (b-h) relative percentages of dominant calcareous benthic foraminifera. (b) Cibicides lobatulus. (c) Buccella frigida s.l. (d) Islandiella helenae. (e) Nonionellina labradorica. (f) Cassidulina neoteretis. (g) Elphidium clavatum. (h) Cassidulina reniforme. Grey vertical shadings; see Fig. 4. Dark grey diamonds: calibrated radiocarbon ages with error ranges.

\section{Interpretation and discussion}

\subsection{Late Weichselian (until $\sim 12.7 \mathrm{ka}$ ) - deglaciation in the Woodfjorden area}

In the Woodfjorden area, the Heinrich Stadial 1 (until $\sim 14.6 \mathrm{ka}$ ) was characterized by a very high IRD content (Fig. 8b) signifying enhanced calving of the glacier front. The increased percentages of fine siliciclastic sediments within this interval (mean: $\sim 4-5 \mu \mathrm{m}$; Fig. $8 \mathrm{a}$ ) point to some contemporaneous intensified meltwater outflows (in this study, sources of siliciclastic sediments were interpreted as terrigenous). Thus, it is assumed that parts of the SvalbardBarents Sea Ice Sheet disintegrated during Heinrich Stadial 1 while stable oxygen isotope records of the NGRIP ice core show that atmospheric temperatures remained cold (Fig. 8g; S. O. Rasmussen et al., 2014). Contrastingly, bottom waters might have been relatively warm and/or saline as indicated by the appearance of the benthic foraminiferal species C. neoteretis (Fig. 8d) as well as the high percentages (up to $\sim 80 \%$ ) of $C$. reniforme (Fig. $5 \mathrm{~h}$ ). The occurrence of C. neoteretis has been connected with a strong influence of AW in bottom waters because this species is assumed to respond to a limited temperature and salinity range as well as to an enhanced food supply (Jennings et al., 2004; Jennings and Helgadottir, 1994; Mackensen et al., 1985; Rytter et al., 2002; Seidenkrantz, 1995; Seidenkrantz et al., 2013; Steinsund, 1994). C. reniforme also prefers saline bottom waters (Hald and Korsun, 1997; Jennings et al., 2004) and may 


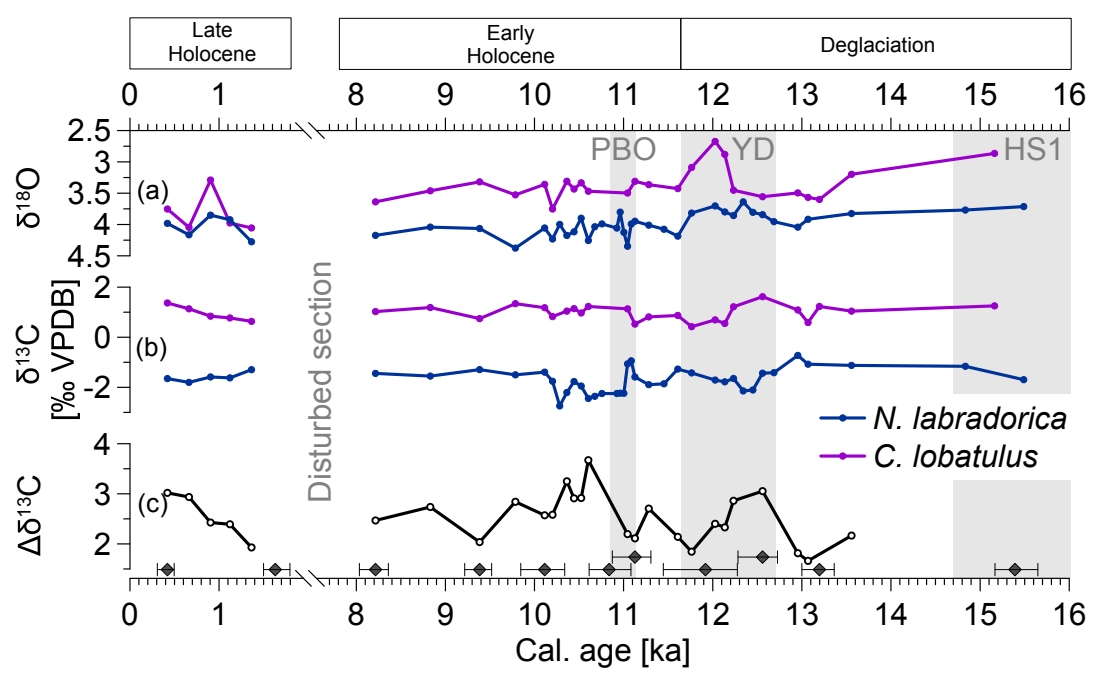

Figure 6. (a) Stable oxygen isotopes (corrected for vital effects and the global ice effect; see Sect. 3.5) and (b) stable carbon isotopes of the epibenthic species Cibicides lobatulus (purple line) vs. the endobenthic species Nonionellina labradorica (blue line). (c) Difference between epi- and endobenthic stable carbon isotope compositions. Grey vertical shadings; see Fig. 4. Dark grey diamonds: calibrated radiocarbon ages with error ranges.

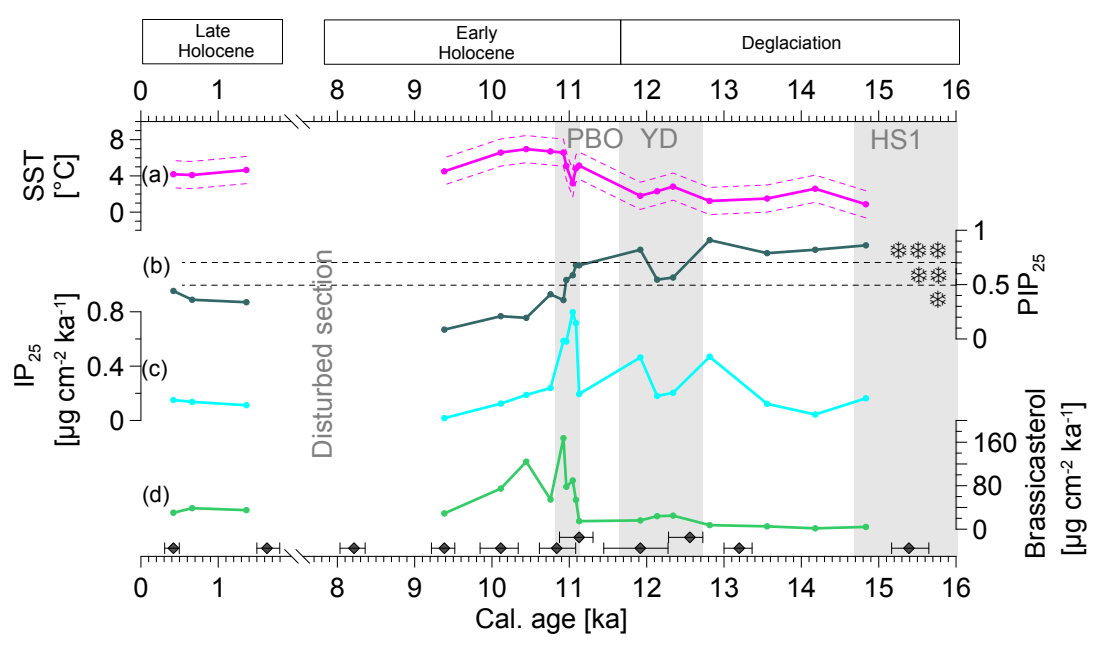

Figure 7. (a) Sea surface temperature (SST) with standard error $\left( \pm 1.5^{\circ} \mathrm{C}\right)$ derived from alkenone unsaturation index $\left(U_{37}^{K}\right)(\mathrm{Brassell}$ et al., 1986; Müller et al., 1998). (b) Phytoplankton (brassicasterol)-IP 25 index $\left(\mathrm{PIP}_{25}\right)$; 0.3 to 0.5: reduced sea ice cover $\left(^{*}\right)$, 0.5 to 0.7 : seasonal sea ice cover $\left({ }^{* *}\right), \ll 0.7$ : extended to perennial sea ice cover ${ }^{* * *}$ ) (Müller et al., 2011). (c) Accumulation rate of the sea ice biomarker $\mathrm{IP}_{25}$. (d) Accumulation rates of phytoplankton biomarker brassicasterol. Grey vertical shadings; see Fig. 4. Dark grey diamonds: calibrated radiocarbon ages with error ranges.

therefore be linked to the intrusion of AW into bottom waters. The advection of AW as a subsurface or even bottom water mass during Heinrich Stadial 1 as well as during earlier Heinrich stadials has already been proposed for the Svalbard area by Rasmussen et al. (2007) and T. L. Rasmussen (2014b). Today, basal melting of tidewater glaciers in Spitsbergen from high advection rates of the relatively warm AW is evident (Luckman et al., 2015). Thus, during Heinrich Stadial 1, the influx of AW in the Woodfjorden area possibly contributed to the destabilization of glacier fronts. Apart from oceanic heat advection, topographic features of the relatively wide Woodfjorden system may have promoted the glacier retreat. Gump et al. (2017) reported a deglaciation of narrower fjords with higher surrounding mountains in southwestern Norway delayed more than 1000 years (see also Stokes et al., 2014).

During the Bølling interstadial ( 14.6-14 ka), a continuing outflow of meltwater is expected as the grain size distribution still exhibits a peak around $7 \mu \mathrm{m}$ (mean: $\sim 4 \mu \mathrm{m}$; Figs. 4a, b and 8a). Simultaneously, the sediment shows a reddish colour (Munsell code 10R4/6) probably connected 


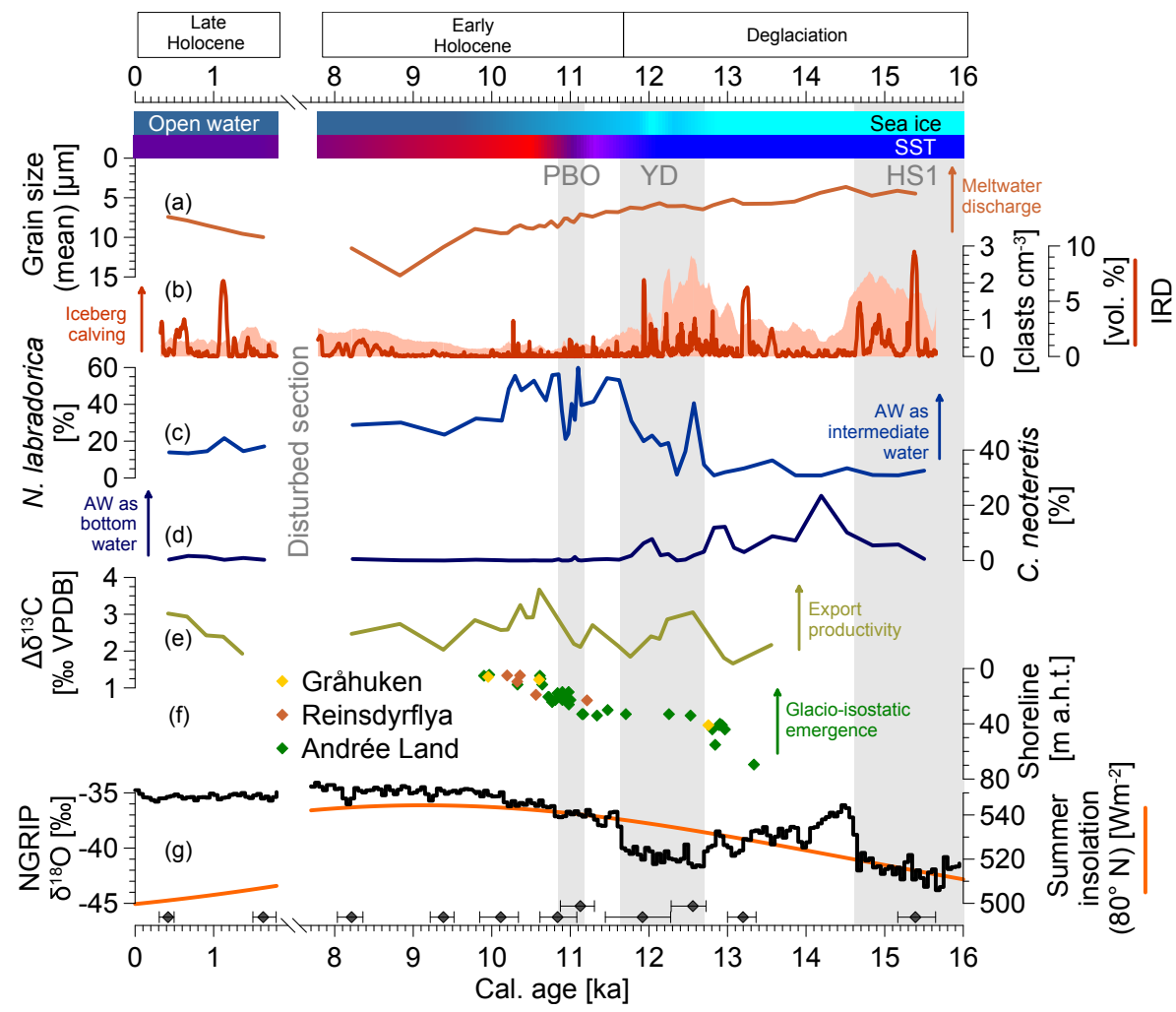

Figure 8. The blueish horizontal bar on top symbolizes sea ice coverage based on biomarker data (PIP 25 index). Red-blue horizontal bar symbolizes (qualitative) sea surface temperatures (red: warm, blue: cold) based on biomarker data (alkenones). (a) Mean grain size of siliciclastic (terrigenous) sediments: low values illustrate deposition of suspended sediment from meltwater plumes (note descending $y$ axis). (b) Volume percentage of ice-rafted debris (solid red line) and number of clasts per cubic centimetre (reddish shading) signifying glacier activity (iceberg calving). (c) Relative percentages of $N$. labradorica. High percentages: Atlantic Water intrusion into intermediate waters delivering nutrients into the photic zone. Note the almost parallel increase in export production as illustrated in (e). (d) Relative percentages of $C$. neoteretis. High percentages: Atlantic Water advection into bottom waters. (e) Offset of epi- and endobenthic $\delta^{13} \mathrm{C}$ values indicating export productivity. (f) Radiocarbon-dated beach ridges in the Woodfjorden area (Forman et al., 2004) illustrating glacio-isostatic emergence (in metres above high tide, $\mathrm{m}$ a.h.t.; note descending $y$ axis). Colours mark different locations as indicated in the legend (locations shown in Fig. 1c). (g) Stable oxygen isotopes from NGRIP ice core (black line; S. O. Rasmussen et al., 2014) and June-July insolation at $80^{\circ} \mathrm{N}$ (orange line; Berger and Loutre, 1991). Grey vertical shadings; see Fig. 4. Dark grey diamonds: calibrated radiocarbon ages with error ranges.

to sediment plumes loaded by glacial flour from the erosion of Devonian Old Red sandstones. Source rocks, i.e. the Wood Bay Formation, crop out at the northwestern coast as well as at the southeastern coast of Woodfjorden (Reinsdyrflya and Andrée Land, respectively; Fig. 1c; Harland, 1998). Melting glaciers from the former lowland may have been a potential source of these reddish sediments. This interpretation is supported by ${ }^{10} \mathrm{Be}$ ages of erratic boulders, which suggest that Reinsdyrflya started to deglaciate during Heinrich Stadial 1 and became ice-free during the Bølling-Allerød (Gjermundsen et al., 2013; Hormes et al., 2013). Rasmussen and Thomsen (2013) reported on pink sediment layers derived from Devonian red beds in sediment cores from the northwestern slope of Svalbard. They interpreted those layers as deposited by meltwater plumes during interstadials. Forwick et al. (2010) also suggested that meltwater run-off connected to retreating glaciers was one possible source for fine reddish sediments deposited close to glacier fronts. Correspondingly, a glacier-proximal position is likely at our core site where tidewater glaciers may have successively waned. Percentages of $C$. neoteretis reached their maximal values during the Bølling (Fig. 8d). Almost simultaneously, this taxon peaked at the southwestern margin (Rasmussen et al., 2007) and at the northern margin of Svalbard (Ślubowska-Woldengen et al., 2007; Ślubowska et al., 2005) as well as in the Laptev Sea (off northern Siberia; Taldenkova et al., 2010) - although with considerably higher values probably deriving from a more direct influence of AW and greater water depths compared to our core location. Massive meltwater outbursts connected to the retreating glaciers possibly caused a deepening of the halocline (cf. Rasmussen and Thomsen, 2004) as the extended cold and relatively fresh surface water mass forced the more saline and thus denser AW to submerge. Accordingly, cold surface waters have been insulated from those 
relatively warm bottom waters, enabling an extended sea ice coverage (see SST and sea ice cover; Fig. 8).

In the course of the Allerød $(\sim 14-12.7 \mathrm{ka})$, the grain size distribution shows a general trend towards slightly coarser sediment (mean: $\sim 5.5-6 \mu \mathrm{m}$; Fig. $8 \mathrm{a}$ ). The coarsening may reflect the retreat of some glaciers to more distal positions. Consequently, less fine-grained material from meltwater plumes would have reached the core location. Szczucin and Zajączkowski (2012) showed that meltwater-derived suspended particulate matter is mostly deposited within a few kilometres from sources in glacier-influenced fjords of Svalbard, as mixing of meltwater with sea water induces flocculation and a subsequent suspension settling. Łącka et al. (2015) observed similar phenomena during the deglaciation of the Storfjord Trough (southern Spitsbergen). A further retreat of the glaciers is also suggested by slightly increasing numbers of (most likely ice-rafted) clasts in the core studied (Fig. 8b), indicating enhanced calving. Radiocarbon-dated beach ridges at the eastern coast of Woodfjorden (Andrée Land) point to a glacio-isostatic emergence of $\sim 20 \mathrm{~m}$ (Forman et al., 2004) in the course of the Allerød (Fig. 8f). This uplift illustrates a massive retreat of the Svalbard-Barents Sea Ice Sheet, at least following Heinrich Stadial 1, as the decreasing ice sheet load caused a successive continental rebound. Despite this Allerød sea level drop, AW advection may have only been slightly reduced (if at all). The inflow of oceanic water into Woodfjorden is not restricted by a sill in a narrower sense, only on the seaward side; the peninsula Reinsdyrflya and the island Moffen are connected by a shallower ridge ( $\sim 80-100 \mathrm{~m}$ depth; see Fig. 1c), possibly slightly decelerating the AW influx.

Towards the transition to the $\mathrm{YD}$, percentages of C. neoteretis increased again (Fig. 8d). This trend is also in agreement with studies from the western, southwestern and northern Svalbard margin (Rasmussen et al., 2007; Ślubowska-Woldengen et al., 2007; Ślubowska et al., 2005) as well as from East Greenland (Jennings et al., 2006), although percentages of $C$. neoteretis were significantly higher at these locations during the Allerød-YD transition. The concomitant appearance of $C$. neoteretis may indicate some AW influx reaching the sea floor (e.g. Lubinski et al., 2001; Steinsund, 1994).

\subsection{Younger Dryas ( 12.7-11.7 ka) - oceanographic transitions and glacier responses}

During the early YD, the benthic foraminiferal fauna was still dominated by $C$. reniforme (Fig. 5h) but percentages of $N$. labradorica rapidly increased (Fig. 8c). The latter species prefers fresh organic matter and is even able to sequester chloroplasts (Bernhard and Bowser, 1999; Cedhagen, 1991). $N$. labradorica shows maximum abundances between 1 and $2 \mathrm{~cm}$ sediment depth (e.g. Ahrens et al., 1997; Alve and Bernhard, 1995; Loubere and Rayray, 2016; Newton and Rowe, 1995). In general, this species is associated with glacier- distal habitats (Korsun and Hald, 1998, 2000). It commonly blooms in connection with enhanced productivity found near oceanic fronts (e.g. Rytter et al., 2002; Sheldon et al., 2016b; Steinsund, 1994). Ślubowska-Woldengen et al. (2007) concluded that rising percentages of $N$. labradorica reflect the approaching Arctic Coastal Front, which divided Atlantic (i.e. the Svalbard Branch) and Arctic waters. Studies from the northern Svalbard continental slope (Koç et al., 2002; Ślubowska et al., 2005) and from the Bellsund trough (western Spitsbergen; Ślubowska-Woldengen et al., 2007) show similar distributions of $N$. labradorica during the YD. According to reconstructions of the Svalbard-Barents Sea Ice Sheet, the Barents Sea itself was no longer covered by this ice sheet at the beginning of the YD (Hormes et al., 2013), enabling the East Spitsbergen Current to surround the Svalbard Archipelago, transporting Arctic Water to the western and northern Svalbard margins and thus causing the development of the Arctic Coastal Front. At the study site in Woodfjorden, AW may have risen in the water column, possibly detaching from the sea floor and enabling the formation of denser winter water at the bottom (see modern situation illustrated in Fig. 2). The rise of AW may have been caused by a slightly declined meltwater outflow (Figs. 4a, 8a), which no longer forced AW to submerge (see Sect. 5.1), and/or by upwelling events. Modern AW intrusion into the fjords of Spitsbergen occurs intermittently (e.g. Carmack and Wassmann, 2006; Wassmann, 2015) and is amplified by windinduced upwelling (Cottier et al., 2005, 2007). Today, easterlies are the prevailing winds at the northern margin of Svalbard (Lind and Ingvaldsen, 2012). Then, northward Ekman transport of surface waters generates (southward) upwelling of subsurface (or intermediate) AW, which subsequently is able to flood the northern shelf of Svalbard (Falk-Petersen et al., 2015; Lind and Ingvaldsen, 2012). A northward retreat of the sea ice edge even amplifies this mechanism (FalkPetersen et al., 2015, and references therein). Comparable conditions might have occurred very frequently at the mouth of Woodfjorden during the early YD, especially because the sea ice coverage was temporarily reduced during this time interval (Fig. 7b). Due to the resultant shallower halocline, an oceanic front (i.e. the Arctic Coastal Front) formed, separating AW from Arctic Water. In the Arctic, AW is commonly associated with enhanced nutrition: nutrients are transported from deeper water masses to the surface in the North Atlantic by winter mixing. The subsequent northward advection of these nutrients promotes primary production at higher northern latitudes while Arctic-derived waters contain only low nutrient amounts (Hunt et al., 2016). Thus, the advection of AW distributes nutrients onto the Arctic shelves, e.g. the shelves and fjords of Svalbard (Carmack and Wassmann, 2006). Therefore, the inflow of (sub)surface AW in the photic zone is interpreted as leading directly to a higher productivity (Carmack and Wassmann, 2006; Falk-Petersen et al., 2015; Sakshaug, 1997). Accordingly, nutrient advection and consequentially increasing phytoplankton blooms in spring 
and early summer may have resulted from such upwelling events during the early YD. High $\delta^{13} \mathrm{C}$ offsets $\left(\Delta \delta^{13} \mathrm{C}\right.$; Fig. 8e) between the epi- (C. lobatulus) and the endobenthic species ( $N$. labradorica) during this time interval point to enhanced remineralization rates and consequentially enhanced export production (see, e.g. Mackensen, 2008; Mackensen and Schmiedl, 2016). Therefore, $\Delta \delta^{13} \mathrm{C}$ values are considered to be valuable palaeoproductivity proxies (Mackensen et al., 2017). Apart from a generally amplified productivity resulting from the stronger summer insolation of the YD (Fig. 8g; Berger and Loutre, 1991), as suggested by Müller and Stein (2014), the increased (export) production possibly resulted from AW incursion into the photic zone. The subsurface advection of the relatively warm AW may also have contributed to further retreat of local glaciers: maximum amounts of IRD (Fig. 8b) and increased percentages of fine-grained sediments (mean: $\sim 6 \mu \mathrm{m}$; Fig. $8 \mathrm{a}$ ) point to increased calving rates and meltwater outflow.

Following the peak appearance of $N$. labradorica, a shift in the faunal distribution is recognized around $12.4 \mathrm{ka}$ : percentages of $C$. reniforme declined while those of $E$. clavatum rose (Fig. 5e, g, h). The dominance of E. clavatum possibly responded to comparable unstable conditions linked to sediment-laden waters and/or high-frequency IRD deposition connected to glacier melting events. E. clavatum is found in extreme modern environments, e.g. affected by very turbid meltwater plumes and/or relatively low salinities, where C. reniforme is not able to survive (Korsun and Hald, 1998, 2000; Steinsund, 1994). Also at the coast of Newfoundland, eastern Canada, a comparable faunal change occurred during a similar time period (Pearce et al., 2014). A shift from relatively stable to unstable conditions during the YD has been inferred from various studies, although this shift may have started at the earliest at $\sim 12.3-12.2 \mathrm{ka}$ (Bakke et al., 2009; Lane et al., 2013; Pearce et al., 2013). The slightly earlier inception at Woodfjorden (and off Newfoundland) may result from dating uncertainties and/or regional differences. Lane et al. (2013) showed, based on lacustrine records from Germany and Norway, that timing differences are likely connected to diverging regional conditions. Interestingly, Łącka et al. (2015) describe a contrary trend to our record with warmer intervals during the late YD in the Storfjord Trough (southern Spitsbergen). Mild summers and a strong seasonality during the YD are also reported from southern and eastern Greenland (Björck et al., 2002; Hall et al., 2008).

Cabedo-Sanz et al. (2013) report about ameliorating, sea-ice-free conditions off northern Norway as early as $\sim 11.9 \mathrm{ka}$. In our record, lower IRD deposition (Fig. 8b) along with gradually declining percentages of E. clavatum (Fig. $5 \mathrm{~g}$ ) are observed during the late YD (from $\sim 12 \mathrm{ka}$ on), which probably indicates a further retreat of glacier fronts into inner fjord positions with a consequential reduction in icebergs melting at the mouth of Woodfjorden. Salvigsen and Høgvard (2006) noted that several glaciers at the head of Bockfjorden, a tributary fjord of the inner Wood- fjorden (Fig. 1c), were disconnected from the main fjord at the end of the YD. Prevailing fine-grained sediments (mean: $\sim 6 \mu \mathrm{m}$; Fig. $8 \mathrm{a})-$ presumably connected to meltwater runoff - also point to some disintegration of glaciers. Birgel and Stein (2004) assumed that a "last deglaciation event" on Svalbard occurred around $12 \mathrm{ka}$, although they proposed a concurrent stable AW advection warming surface waters. In contrast, our data indicate that the spreading of cold and low-salinity surface waters - resulting from enhanced inputs of meltwater - likely deepened the Atlantic-derived waters. Accordingly, AW-influenced bottom waters may have resulted in the observed slightly increasing percentages of C. neoteretis (Fig. 8d) during the late YD (e.g. Jennings et al., 2004; Rytter et al., 2002; Steinsund, 1994). As surface waters were consequently better insulated from relatively warm AW, SSTs probably fell again while sea ice expanded (see Fig. 7a, b). However, a perennial closed sea ice cover in Woodfjorden, as suggested by Brückner and Schellmann (2003), seems unlikely as the data above show continuous deposition of IRD during the entire YD (Fig. 8b), even when maximum PIP $_{25}$ values are observed (Fig. 7b). This leads to the inference that broken-up sea ice at least during summer enabled high productivity of sea ice diatoms and iceberg calving and dispersal. Hence, it remains unclear if $C$. neoteretis responded rather to those food pulses during summer, as proposed by Wollenburg et al. (2004), than to the presence of AW.

The retreat of glaciers during the YD as suggested by our data is further supported by studies based on radiocarbondated beach ridges or moraines (Mangerud and Landvik, 2007; Salvigsen and Høgvard, 2006; Salvigsen and Österholm, 1982) as well as on ${ }^{10} \mathrm{Be}$-dated boulders (Reusche et al., 2014). They point to the absence of any YD glacier advance along the western and northern coasts of Spitsbergen. Possible contemporaneous glacier advances in several other regions of Svalbard - especially in Isfjorden (central Spitsbergen) - still remain under debate (Birgel and Stein, 2004; Boulton, 1979; Forwick, 2005; Svendsen et al., 1996). Nonetheless, YD glacier retreats have also been observed in the Disko Bay, western Greenland, where the Jakobshavn Isbræ retreated from $\sim 12.2 \pm 0.6 \mathrm{ka}$ onwards (Rinterknecht et al., 2014). Rinterknecht et al. (2014) connect this retreat to warm ocean currents, which destabilized the marine terminating glacier by basal melting. A possibly ongoing deglaciation already at the onset of the YD and a further glacier retreat in the course of the YD is controversially discussed for the Scottish Highlands (Bromley et al., 2014; Small and Fabel, 2016).

\subsection{Early Holocene ( 11.7-7.8 ka) - amelioration of environmental conditions}

Climatic conditions were ameliorated during the YD-early Holocene transition (starting $\sim 11.7 \mathrm{ka}$ ) as summer insolation approached its maximum values (Fig. 8g; Berger and 
Loutre, 1991). Also, the high offset between $\delta^{18} \mathrm{O}$ values of C. lobatulus and N. labradorica (Fig. 6a) - which already started during the second half of the YD and persists during the entire early Holocene - presumably indicates increasing seasonal differences due to the contrast between high summer and low winter insolation (Fig. 8g), as suggested by Rasmussen et al. (2012) for the Isfjord. Indeed, C. lobatulus calcifies in summer, whereas $N$. labradorica calcifies in spring or early summer (Zajączkowski et al., 2010). Rising $\Delta \delta^{13} \mathrm{C}$ and lower $\delta^{13} \mathrm{C}$ values in $N$. labradorica (Figs. 6b, 8e) may indicate higher organic matter inputs deriving from enhanced primary production. High percentages of N. labradorica (Fig. 8c) point to a growing influence of the Arctic Coastal Front with intensified AW circulation in intermediate waters (see Sect. 5.2). Simultaneously, declining IRD amounts suggest a significant reduction in iceberg rafting (Fig. 8b). Grain size measurements illustrate some coarsening (Fig. 8a), likely resulting from the retreat of glaciers to innermost positions in the fjords as smaller amounts of fine-grained suspended material associated with meltwater plumes reached the core location (see Szczucin and Zajączkowski, 2012).

Between $\sim 11.1$ and $\sim 10.8 \mathrm{ka}$, a short-term shift in the faunal assemblage is recognized: percentages of $N$. labradorica dropped while those of E. clavatum and $C$. reniforme increased (Fig. 5e, g, h). This likely illustrates a northward shift of the Arctic Coastal Front (away from the coast) and a consequentially stronger influence of cold and fresh Arctic waters. Also, some surface cooling is indicated by rapidly decreasing SSTs (Fig. 7a). E. clavatum - an opportunistic species (e.g. Korsun and Hald, 2000; Newton and Rowe, 1995) - took advantage of these deteriorated conditions. Increasing percentages of $C$. reniforme may reflect the presence of some saline AW at the fjord floor as this species is reported to respond to Atlantic (Intermediate) Water, e.g. at the eastern Greenland shelf (Jennings and Helgadottir, 1994). Several studies describe simultaneous and similar faunal changes around Svalbard (Rasmussen et al., 2012; T. L. Rasmussen et al., 2014a; Skirbekk et al., 2010; Ślubowska-Woldengen et al., 2007; Ślubowska et al., 2005), generally associated with the Preboreal Oscillation (PBO) cooling interval (Björck et al., 1996). Some divergence in the timing of the PBO - especially at the Hinlopen trough (Ślubowska et al., 2005) may be due to chronological uncertainties and possibly distinct reservoir ages, as suggested by T. L. Rasmussen et al. (2014a). Different trigger mechanisms have been suggested for the PBO inception. Meltwater discharge from the disintegrating Fennoscandian Ice Sheet into the Baltic Ice Lake and subsequent drainage into the Nordic Seas have been proposed as one possible cause of the PBO cooling (Björck et al., 1996, 1997; Hald and Hagen, 1998). In contrast, Fisher et al. (2002) assumed that a single meltwater flood event from Lake Agassiz into the Arctic Ocean resulted in an expansion and thickening of sea ice as well as in fresher North Atlantic surface waters.
Despite this cooling, there is no evidence for any significant glacier re-advance in the Woodfjorden area as IRD deposition did not change much (Fig. 8b). Grain size measurements still illustrate high but steadily decreasing fractions of fine sediments $(\sim 7-8.5 \mu \mathrm{m}$; Fig. $4 \mathrm{a}, \mathrm{d})$, which might reflect continuous meltwater discharge and thus further deglaciation. Nevertheless, increasing percentages of coarser sediments $(\sim 20 \mu \mathrm{m})$ are also observed during the PBO (Fig. 4a, d). These coarser sediments probably resulted from sea-icerafted deposition as sediments $>10 \mu \mathrm{m}$ are interpreted as transported by sea ice (Hebbeln, 2000). During previous time intervals, enhanced percentages of this coarser fraction $(\sim 20 \mu \mathrm{m})$ were masked because they were diluted by high amounts of meltwater-transported finer sediment (e.g. grain size distribution at $\sim 13.9 \mathrm{ka} ;$ Fig. $4 \mathrm{~d}$ ). In contrast, presumed sea-ice-rafted debris is better recognizable during the PBO when the grain size distribution is less influenced by suspended sediments derived from meltwater plumes (see Fig. 4d). Sea ice biomarkers exhibit a decreasing trend indicating a moderate sea ice coverage (Fig. 7b), but peak values of $\mathrm{IP}_{25}$ (Fig. 7c) illustrate a high number of sea ice diatoms, which possibly characterize a sea ice edge position at the mouth of Woodfjorden. Thus, the deposition of sea-ice-rafted material at the core site seems realistic. Subsequently, maximum accumulation rates of the phytoplankton marker brassicasterol (Fig. 7d) point to algal blooms in spring-summer under open water conditions that persisted throughout the early Holocene (see PIP 25 values; Figs. $7 \mathrm{~b}$ and 8 ).

At the end of the PBO, N. labradorica rapidly recovered (reaching up to $\sim 50 \%$; Fig. 8 c), while E. clavatum and $C$. reniforme declined in percentage (Fig. $5 \mathrm{~g}, \mathrm{~h}$ ). This faunal transition probably reflects the return of the Arctic Coastal Front in the vicinity of the core site, accompanied by rising AW intruding into intermediate water masses in the fjord (see Sect. 5.2). This hydrographic change was likely a response to the onset of the Holocene Thermal Maximum (HTM) in Svalbard, at $\sim 10.8 \mathrm{ka}$ (Miller et al., 2010), when summer temperatures significantly exceeded modern temperatures due to the higher summer insolation (Fig. 8g; Berger and Loutre, 1991). Peaks in the ARBF, with more than 50000 ind. $\mathrm{cm}^{-2} \mathrm{ka}^{-1}$, as well as enhanced accumulation rates of brassicasterol (Fig. d), indicate high food supplies. The observed increase in $\Delta \delta^{13} \mathrm{C}$ values (Fig. 8e) implies a high export productivity lasting until $\sim 10.4 \mathrm{ka}$. This may be linked to the presence of AW as a subsurface or even surface water mass, hence amplifying productivity in the photic zone. The appearance of the thermophilous mussel Mytilus edulis at the outer part of Woodfjorden (Reinsdyrflya) supports the assumption of a surface injection of $\mathrm{AW}$ at least from $\sim 10.6 \mathrm{ka}$ on $\left(9815 \pm 80{ }^{14} \mathrm{C}\right.$ a; Salvigsen, 2002). Several studies around Spitsbergen report about a benthic faunal pattern comparable to the record above during the HTM (Groot et al., 2014; Rasmussen et al., 2012; Skirbekk et al., 2010; Ślubowska-Woldengen et al., 2007). ŚlubowskaWoldengen et al. (2008) showed that $N$. labradorica reached 
maximum percentages at sites influenced by the WSC or the Svalbard Branch. At the mouth of Woodfjorden, percentages of I. helenae (Fig. 5d) rose at the onset of the HTM. This species has been connected to sea ice algae blooms in various studies (mostly lumped with I. norcrossi; e.g. Steinsund, 1994). Because sea ice coverage shows a decreasing trend (see PIP 25 ; Fig. 7b), whereas alkenone-based SSTs reached peak values of $\sim 7^{\circ} \mathrm{C}$ (Fig. 7a), it seems more likely that I. helenae did not respond specifically to sea ice algae blooms but rather to an enhanced productivity (probably due to open waters), as already proposed by Polyak et al. (2002), Seidenkrantz (2013) and Wollenburg et al. (2004).

During the HTM, increasing SSTs (based on planktic foraminiferal assemblages) were reconstructed at the western Svalbard continental slope (Hald et al., 2004), south of Spitsbergen at the Storfjorden slope (T. L. Rasmussen et al., 2014a), and at the western Barents slope (Sarnthein et al., 2003). Lacustrine records from NW Spitsbergen indicate maximum temperatures based on alkenones until $\sim 10.5 \mathrm{ka}$ (van der Bilt et al., 2016). Carbonara et al. (2016) and RigualHernández et al. (2017), report about maximum concentrations of diatoms and coccoliths (mainly warm water species) and inferred a causally strengthened advection of AW during the HTM south of Spitsbergen. Thus, a significant warming in the Svalbard area occurred during this time interval, with temperatures exceeding modern temperatures (compare alkenone-based SST data in Fig. 7a with hydrographic data in Fig. 2 and in Rasmussen and Thomsen, 2014; T. L. Rasmussen et al., 2014a).

Iceberg production remained low during the HTM. From $\sim 10.1 \mathrm{ka}$ on, IRD percentages were reduced to a minimum (Fig. 8b) - although slightly increasing at around $9 \mathrm{ka}-$ indicating a retreat of most glaciers to innermost fjord positions while some large tidewater glaciers (e.g. Monacobreen; Fig. 1c) stayed connected to the fjord system during the early Holocene. Radiocarbon-dated beach ridges show a contemporary drop in relative sea level almost down to the present level (Fig. 8f; Forman et al., 2004) in response to the deglaciation of Spitsbergen with the consequential rebound persisting into the HTM.

Grain size distribution during the HTM exhibits maxima around $20 \mu \mathrm{m}$ (Fig. 4a) that may indicate relatively high fluxes of sea-ice-rafted debris. In this scenario, some winter sea ice cover would have been present, although sea ice biomarker concentration is low during the interval (see $\mathrm{PIP}_{25}$ minima in Fig. 7b). The PIP $_{25}$ index is based on sea ice diatoms and is thought to respond to spring-summer conditions (Müller et al., 2011). However, a coarsening of the sediment due to stronger bottom currents cannot be excluded.

After $\sim 10.1 \mathrm{ka}$ another slight shift in the faunal distribution is recognized (Fig. 5): N. labradorica declined whereas C. reniforme rose again (Fig. 5e, h). This faunal change may be linked to a repeated northward movement of the Arctic Coastal Front away from the core site in concert with submerging AW. Following a significant peak in the ARBF at $\sim 10.1 \mathrm{ka}$, all proxies for productivity reveal a decreasing trend (i.e. $\Delta \delta^{13} \mathrm{C}$, accumulation rates of brassicasterol and benthic foraminifera; Figs. 5a, 7d, 8e) indicating a decreasing AW influence in the photic zone. Slightly cooler conditions have been consistently reported from the Storfjord Trough (southern Spitsbergen) at the end of the early Holocene, probably due to a stronger influence of Arctic Water (Łącka et al., 2015).

Around $8.8 \mathrm{ka}$, a further coarsening of the sediment is observed (maximum percentages $\sim 45-50 \mu \mathrm{m}$, mean: $\sim 15 \mu \mathrm{m}$; Figs. 4a, 8a). This shift in the grain size distribution may indicate higher current velocities. The pronounced skewness towards coarse sediments seen in the grain size distribution points to winnowing and/or bypass of the fine fraction (see grain size distribution at $\sim 8.8 \mathrm{ka}$ in Fig. $4 \mathrm{~d}$ ). The epibenthic species C. lobatulus - commonly connected to strong bottom currents (Hald and Korsun, 1997; Hansen and Knudsen, 1995; Steinsund, 1994) - displays slightly increased proportions during this time period (Fig. 5b). Higher percentages of $B$. frigida s.l. (Fig. 5c) support these findings because the species develops preferentially in coarse sediments (Steinsund, 1994). This taxon has also been connected to ice edge algal blooms (Hald and Steinsund, 1996; Steinsund, 1994). Here, however, this seems unlikely; analogous to I. helenae, its presence rather corresponds to reduced sea ice cover conditions during spring-summer, as inferred from declining PIP $_{25}$ values (Figs. 5c, 7b). Seidenkrantz (2013) suggested that $B$. frigida thrives right after the retreat of sea ice. Apart from the species' preference for coarse sediments, the occurrence of $B$. frigida s.l. seems to be mainly controlled by the presence of open waters enabling primary production and high organic matter fluxes to the sea floor. Consistently, B. frigida is reported to feed on fresh particulate organic matter in the Northeast Water Polynya (northeastern Greenland; Newton and Rowe, 1995). An enhanced productivity at the mouth of Woodfjorden is indeed indicated by increasing $\Delta \delta{ }^{13} \mathrm{C}$ values (Fig. 8e) simultaneously matching peak percentages of B. frigida s.l. at around $8.8 \mathrm{ka}$ (Fig. $5 \mathrm{c}$ ).

\subsection{Late Holocene $(\sim 1.8-0.4 \mathrm{ka})$ - aftermath of the neoglaciation}

In comparison with the early Holocene, distinct differences in the benthic foraminiferal fauna mark the last $\sim 1,400$ years of our record. The faunal composition suggests frequent AW incursions, temporarily as bottom water mass: the $N$. labradorica abundance decreased to $\sim 13-22 \%$ (Fig. 8c), whereas $C$. reniforme exhibits percentages up to $\sim 31 \%$ (Fig. 5h). C. reniforme may indicate more saline conditions in bottom waters linked to the presence of AW at the sea floor (Hald and Korsun, 1997; Jennings et al., 2004; Jennings and Helgadottir, 1994). Enhanced percentages of the opportunistic species E. clavatum (up to $\sim 28 \%$ Fig. $5 \mathrm{~g}$ ) point to unstable conditions, e.g. high inter-annual variability in environmental conditions. Nonetheless, I. helenae reached pro- 
portions comparable to those of the HTM (>5\%; Fig. 5d), reflecting still sufficient food availability. Increasing $\Delta \delta^{13} \mathrm{C}$ values (Fig. 8e) characterize this interval, likely responding to the temporary influence of AW in subsurface waters transporting nutrients into the photic zone. Late Holocene seasonally ice-free waters (see Fig. 7b) enabled primary productivity despite lower SSTs than those inferred above for the HTM interval $\left(\sim 4^{\circ} \mathrm{C}\right.$; Fig. $\left.7 \mathrm{a}\right)$, very likely due to the decreasing summer insolation and reduced seasonal temperature contrast (Berger and Loutre, 1991; Fig. 8g). Cooling in the Fram Strait area during the late Holocene is reported at various locations and assigned reduced insolation (e.g. Hald et al., 2004; Müller et al., 2012; Rasmussen et al., 2012; Rigual-Hernández et al., 2017; Ślubowska-Woldengen et al., 2007; Werner et al., 2013). Although sea ice biomarkers suggest open waters during summer (Figs. 7b, 8), increased proportions of $\sim 20$ and $\sim 50 \mu \mathrm{m}$ grain size fractions (Fig. 4a) may imply the deposition of (winter) sea-ice-rafted debris (see Sect. 5.3).

Parallel to this cooling, a slight increase in IRD percentages indicates enhanced glacier activity with intensified iceberg production (Fig. 8b) in the Woodfjorden area. Furrer et al. (1991) report about advances of Monacobreen into Liefdefjorden (Fig. 1c) during the Older Subatlantic $\left(\sim 1.2 \mathrm{ka} ; 1315 \pm 100{ }^{14} \mathrm{C}\right.$ a), whose glacier ice front reached Lernerøyane, a small archipelago $\sim 6 \mathrm{~km}$ from its modern position. Advancing glaciers have also been reported in central Spitsbergen during a similar time period (Baeten et al., 2010; Humlum et al., 2005). The growth of Monacobreen possibly responded to the neoglacial cooling trend (as described by Porter and Denton, 1967), which led to waxing of Arctic glaciers (e.g. Miller et al., 2010; Solomina et al., 2015,2016 ), and is reflected in increased IRD deposition in the present study.

In contrast to conditions inferred above, some other studies state a general warming trend (Bonnet et al., 2010; D’Andrea et al., 2012; Jernas et al., 2013; Majewski et al., 2009; Spielhagen et al., 2011; Werner et al., 2011) as well as a strengthened influx of AW during the last 2 millennia in the Svalbard area (Groot et al., 2014; Rasmussen et al., 2012; Sarnthein et al., 2003; Ślubowska et al., 2005). However, as the midHolocene is missing in the present record (see Sect. 4.1), we can only compare the early vs. late Holocene. As the late Holocene is marked by cooler conditions than those prevailing during the HTM, a link to the neoglaciation is assumed, but the actual trend from the mid- to the late Holocene is unknown.

\subsection{The role of Atlantic Water in the deglaciation history} of the Svalbard-Barents Sea Ice Sheet

Around the Svalbard margins, intrusion of AW is generally causally linked to the retreat of glaciers since the late Weichselian (Hormes et al., 2013; Jessen et al., 2010; Klitgaard Kristensen et al., 2013; Skirbekk et al., 2010; Ślubowska-
Woldengen et al., 2007; Ślubowska et al., 2005). The subsurface inflow of AW into fjords possibly melted tidewater glaciers from underneath, as proposed by Hormes et al. (2013). Today, submarine melting of tidewater glaciers induced by warm ocean currents is observed in the Arctic, e.g. in Alaska (Bartholomaus et al., 2013; Motyka et al., 2003), Greenland (Holland et al., 2008; Inall et al., 2014; Straneo et al., 2010) and Svalbard (Luckman et al., 2015), as well as in Antarctica, i.e. on the Antarctic Peninsula (Cook et al., 2016; Padman et al., 2012; Wouters et al., 2015).

Interpreting the appearance of $C$. neoteretis, numerous studies assume that the intensification of AW inflow along the Svalbard margin occurred relatively simultaneously during the Bølling-Allerød (Klitgaard Kristensen et al., 2013; Rasmussen et al., 2007; Ślubowska et al., 2005). In the Laptev Sea, this species has been connected to Atlanticderived water from $\sim 15.4 \mathrm{ka}$ onwards (Taldenkova et al., 2010). AW presence is also inferred prior to $\sim 14 \mathrm{ka}$ off West Greenland (Sheldon et al., 2016a). At the margin of the Arctic Ocean, north of Svalbard, C. neoteretis showed high abundances from at least $24 \mathrm{ka}$ onwards (Wollenburg et al., 2004). Despite the assumed intrusion of relatively warm water masses, planktic foraminifera assemblages indicate low subsurface temperatures without considerable changes far into the YD along the W Barents slope (Sarnthein et al., 2003) and along the W Svalbard margin (Hald et al., 2004). Thus, a subsurface or bottom water inflow of relatively warm AW is assumed during the Bølling-Allerød, while surface waters remained cold.

The YD cold event has been studied extensively. This cold reversal was most likely initiated by a massive glacial lake drainage into the Arctic Ocean that reduced the Atlantic Meridional Overturning Circulation (Broecker, 2006; Broecker et al., 1989; Fahl and Stein, 2012; Murton et al., 2010; Stein et al., 2012; Tarasov and Peltier, 2005). Nonetheless, the influence of AW is seen at numerous locations around Svalbard, at least during the early YD and possibly temporarily (e.g. Rasmussen et al., 2007; Ślubowska et al., 2005; this study, see Fig. 8c, d). A shift of the Arctic Coastal Front towards the study areas at the northern Svalbard margin characterizes the situation during the YD. The proximal position of this oceanic front is linked to an initial AW intrusion into intermediate waters of Woodfjorden providing higher food supplies (Fig. 8e) while contributing to the retreat of tidewater glaciers (Fig. 8a, b).

During the early Holocene, the Nordic Seas, the Fram Strait and Barents Sea were characterized by a high AW inflow (e.g. Bauch et al., 2001; Carbonara et al., 2016; Groot et al., 2014; Müller and Stein, 2014; Rigual-Hernández et al., 2017; Risebrobakken et al., 2011; Telesiński et al., 2015; Werner et al., 2013, 2016), coinciding with a general warming trend in the entire Svalbard region - especially after the PBO (e.g. Hald et al., 2004; Rasmussen et al., 2012; Sarnthein et al., 2003; Skirbekk et al., 2010; Ślubowska et al., 2005; this study, see Fig. 7a). This trend is in agreement with 

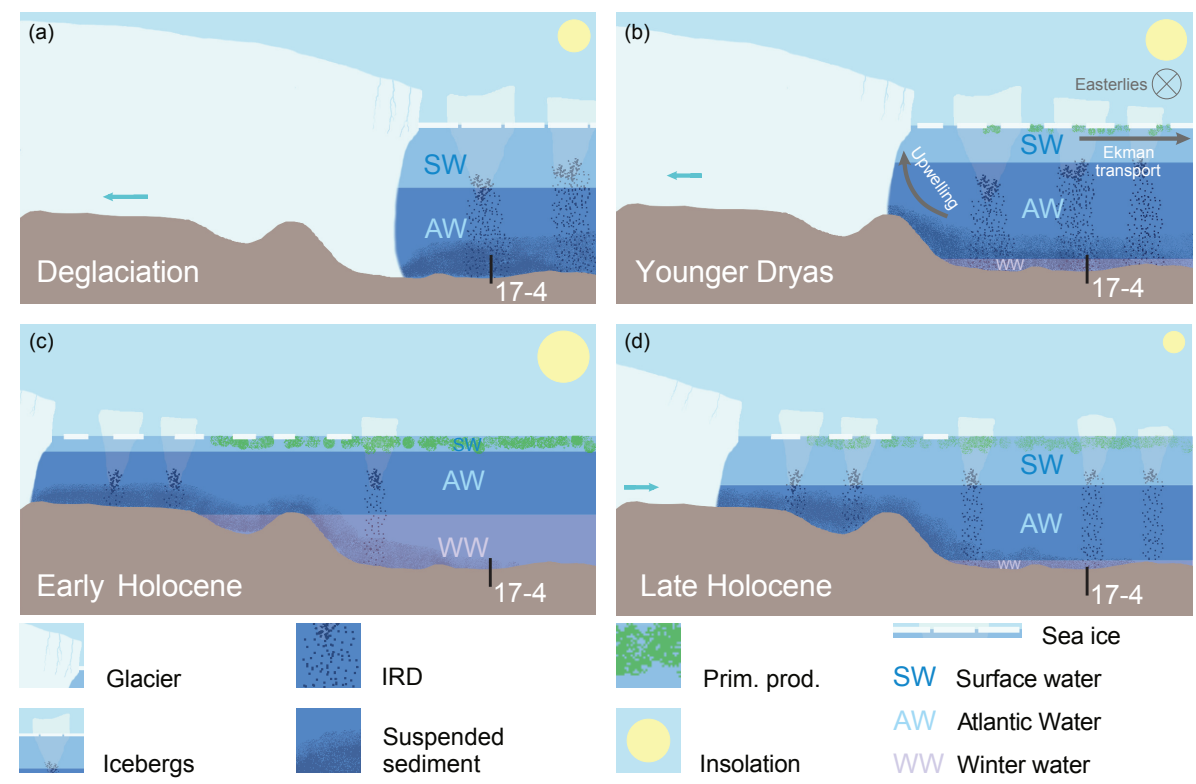

Figure 9. Environmental conditions in Woodfjorden during (a) the deglaciation, (b) the Younger Dryas, (c) the early Holocene and (d) the late Holocene. Black bars mark the location of sediment core GeoB10817-4. Glacier retreats or advances are marked by turquoise arrows. Yellow circles symbolize insolation changes (Berger and Loutre, 1991). The crossed circle in (b) signifies easterlies (blowing perpendicular to the profile) triggering a northward Ekman transport of the surface waters, which entailed an upwelling of intermediate waters (i.e. AW; see Lind and Ingvaldsen, 2012).

the early Holocene warming observed in the entire North Atlantic (Marchal et al., 2002).

The interruption of the warming trend during the PBO occurred almost simultaneously around Svalbard but is more pronounced in northern locations (T. L. Rasmussen et al., 2014a; Skirbekk et al., 2010; Ślubowska et al., 2005; this study, see Figs. 5, 7) than along the (south)western margin of Svalbard (Rasmussen et al., 2012; T. L. Rasmussen et al., 2014a; Ślubowska-Woldengen et al., 2007). Accordingly, it seems likely that the PBO was triggered by a vast meltwater flood from the Mackenzie River area into the Arctic Ocean (Fisher et al., 2002) than by a meltwater discharge from the Fennoscandian Ice Sheet into the Nordic Seas as assumed earlier (Björck et al., 1996). Thus, northern sites may have been more strongly affected by the resulting colder and fresher surface waters and the expansion of a thicker pack ice, which concurred to force AW to sink deeper in the water column.

Nevertheless, as discussed above, AW was present at the northern margin of Spitsbergen during the last 2 millennia, although its influx was weaker and its position possibly deeper in the water column when compared to HTM conditions (Fig. 8c). Various studies report similar oceanographic conditions during this time interval (e.g. Hald et al., 2004; T. L. Rasmussen et al., 2014a; Skirbekk et al., 2010; Ślubowska-Woldengen et al., 2007; Ślubowska et al., 2005). Contrary to the HTM and the YD, there are indications of glacier advances regardless of the AW advec- tion during the late Holocene (Fig. 8a, b), possibly resulting from the lower summer insolation of the interval (Berger and Loutre, 1991; see Fig. 8g). Additionally, the AW incursion into Woodfjorden as a relatively deep water mass may have been of minor influence on glacier fronts as tidewater glaciers may only have been present in the shallower inner parts of the fjord system during the late Holocene (Furrer et al., 1991; Salvigsen and Høgvard, 2006). Hence, the glacier dynamics were possibly decoupled from AW advection during the late Holocene.

\section{Conclusions}

Multi-proxy analyses of sediment core GeoB10817-4 from the mouth of Woodfjorden (northern Spitsbergen) enabled us to document ocean-ice interactions since the deglaciation (since $\sim 15500$ years) at the northern margin of Svalbard, providing insights into glacier activity as well as into bottom, intermediate and surface water conditions, including sea ice coverage.

- The deglaciation period (until $\sim 12.7 \mathrm{ka}$; excluding the Younger Dryas) was marked by a disintegrating Svalbard-Barents Sea Ice Sheet, as illustrated by high calving rates and enhanced meltwater inputs. Cold surface waters were covered by extensive sea ice, while early intrusions of Atlantic Water as a bottom water mass occurred (Fig. 9a). 
- During the early Younger Dryas $(\sim 12.7-12.4 \mathrm{ka})$, Atlantic Water was still advected as an intermediate water mass, probably connected to a coastward shift of the Arctic Coastal Front. Its intrusion was accompanied by warmer surface waters and high iceberg melting rates, which may have been linked to the retreat of some tidewater glaciers towards the fjord heads (Fig. 9b). During the late Younger Dryas $(\sim 12.4-11.7 \mathrm{ka})$, surface waters cooled while sea ice extended and Atlantic Water temporarily penetrated into bottom waters.

- Conditions improved during the early Holocene ( $\sim 11.7-7.8 \mathrm{ka})$, with an increasing subsurface Atlantic Water inflow, and were briefly interrupted during the Preboreal Oscillation. This deterioration occurred almost simultaneously around Svalbard, but was more pronounced at the northern margin of Svalbard than in the south. During the succeeding Holocene Thermal Maximum, sea surface temperatures reached their maximum, surpassing modern temperatures. Productivity flourished and sea ice coverage declined. Most glaciers retreated to innermost fjord positions during this interval. Only single tidewater glaciers survived (especially Monacobreen) (Fig. 9c).

- The early vs. late Holocene depict distinct environmental conditions. Productivity gradually increased in the course of the late Holocene $(\sim 1.8-0.4 \mathrm{ka})$ while Atlantic Water temporarily sank from intermediate to bottom waters. Even though sea surface temperatures were lower than during the early Holocene, sea ice coverage was reduced. High iceberg production possibly responded to some late Holocene glacier advance (neoglaciation) in response to low summer insolation (Fig. 9d).

- From the deglaciation on, the presence of Atlantic Water - in bottom as well as in intermediate waters - is connected to retreating glaciers at the northern Svalbard margin, while during the late Holocene, glaciers might have grown despite relatively constant inflow of Atlantic Water (possibly below surface).

- The Holocene Thermal Maximum includes - apart from a few differences (e.g. considerable higher summer insolation, dropping relative sea level due to the glacioisostatic rebound) - numerous similarities to a future warming: sea surface temperatures were most likely warmer than today, resulting in a reduced sea ice coverage and consequential open waters that enabled high primary production. Already today, reduced sea ice promotes increasing phytoplankton blooms (Arrigo and van Dijken, 2011, 2015). During the Holocene Thermal Maximum, subsurface intrusion of warm Atlantic Water contributed to the melting and retreat of glaciers to inner fjord positions, a phenomenon that is also observed today, e.g. at Svalbard's tidewater glaciers (Luckman et al., 2015). Thus, environmental conditions during the Holocene Thermal Maximum are comparable with the already ongoing global warming, at least for the Svalbard region.

Data availability. Supplement data are available on PANGAEA: https://doi.pangaea.de/10.1594/PANGAEA.882243. 
Appendix A: Lists of benthic foraminiferal species appearing in sediment core GeoB10817-4

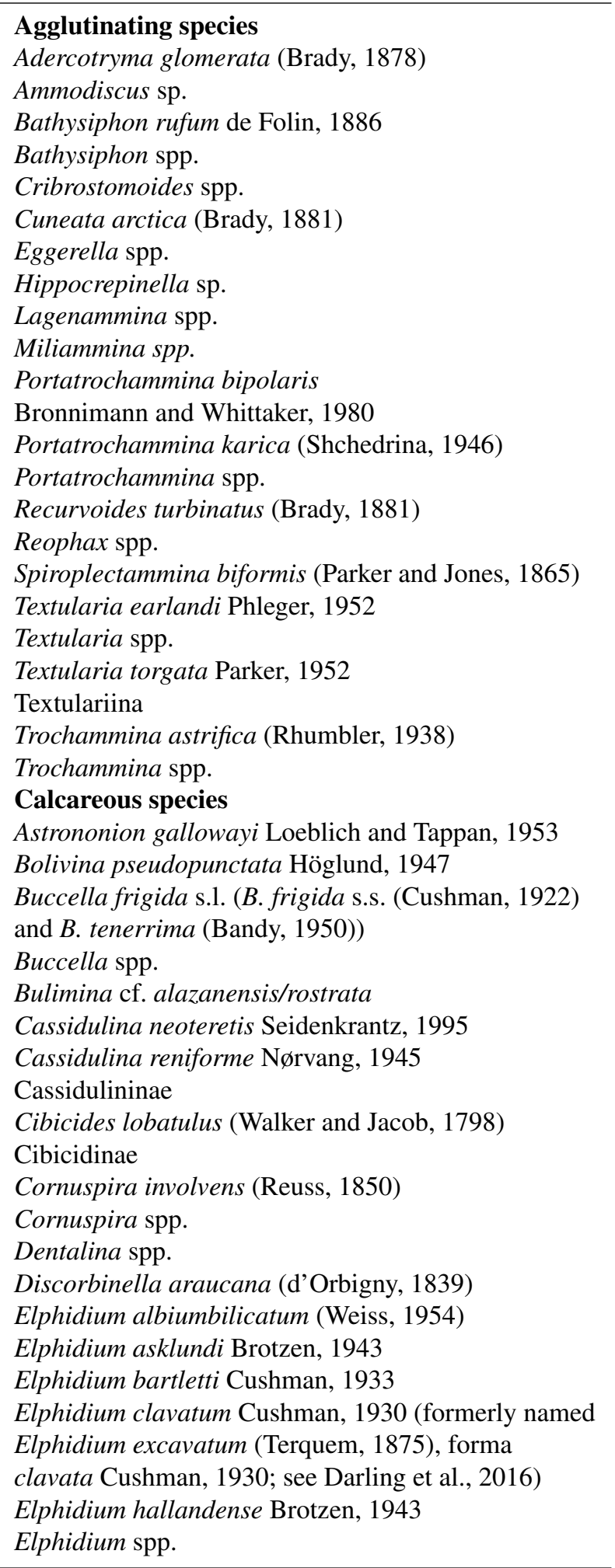

Elphidium williamsoni Haynes, 1973

Epistominella spp.

Fissurina orbignyana Seguenza, 1862

Fissurina spp.

Glandulina ovula d'Orbigny, 1846

Globobulimina auriculata Bailey, 1894

Globobulimina spp.

Globobulimina turgida (Bailey, 1851)

Globulina spp.

Haynesina spp.

Islandiella helenae Feyling-Hanssen and Buzas, 1976

Islandiella islandica (Nørvang, 1945)

Islandiella norcrossi (Cushman, 1933)

Islandiella spp.

Lagena distoma Parker and Jones, 1864

Lagena laevis (Montagu, 1803)

Lagena striata (d'Orbigny, 1839)

Melonis barleeanus (Williamson, 1858)

Melonis spp.

Miliolida

Miliolinella spp.

Nodosaria spp.

Nonionella auriculata Heron-Allan and Earland, 1930

Nonionella turgida (Williamson, 1858)

Nonionellina labradorica (Dawson, 1860)

Oolina hexagona (Williamson, 1848)

Pullenia quinqueloba (Reuss, 1851)

Quinqueloculina seminula (Linné, 1758)

Quinqueloculina spp.

Quinqueloculina stalkeri Loeblich and Tappan, 1953

Robertina spp.

Rosalina spp.

Rotaliina

Stainforthia loeblichi s.l. (S. loeblichi s.s.

(Feyling-Hanssen, 1954) and S. concava Höglund, 1947)

Stainforthia spp.

Trifarina angulosa (Willamson, 1858)

Trifarina fluens (Todd, 1947)

Triloculina spp.

Triloculina trihedral Loeblich \& Tappan, 1953

Uvigerina mediterranea Hofker, 1932

Uvigerina spp. 


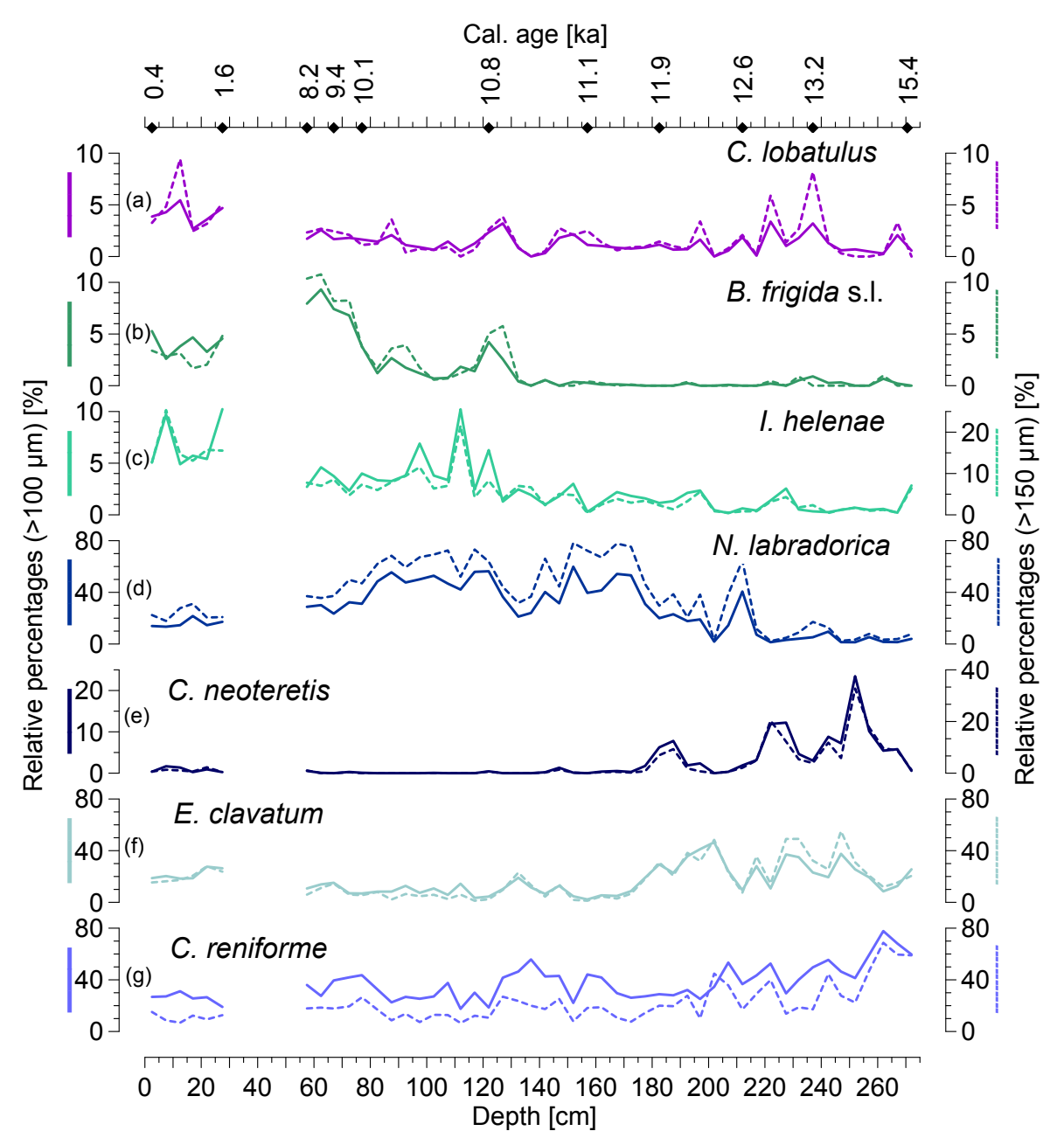

Figure A1. Relative percentages of the dominant calcareous benthic foraminifera. Comparison of fraction $>100 \mu \mathrm{m}$ (solid lines) vs. fraction $>150 \mu \mathrm{m}$ (dashed lines). (a) Cibicides lobatulus. (b) Buccella frigida s.l. (c) Islandiella helenae. (d) Nonionellina labradorica. (e) Cassidulina neoteretis. (f) Elphidium clavatum. (g) Cassidulina reniforme. Note similar pattern of the faunal distributions. The highest offset can be recognized for $N$. labradorica and $C$. reniforme because the majority of $N$. labradorica appears in the $>150 \mu \mathrm{m}$ fraction whereas the majority of $C$. reniforme appears in the $>100 \mu \mathrm{m}$ fraction. Black diamonds: calibrated radiocarbon ages. 


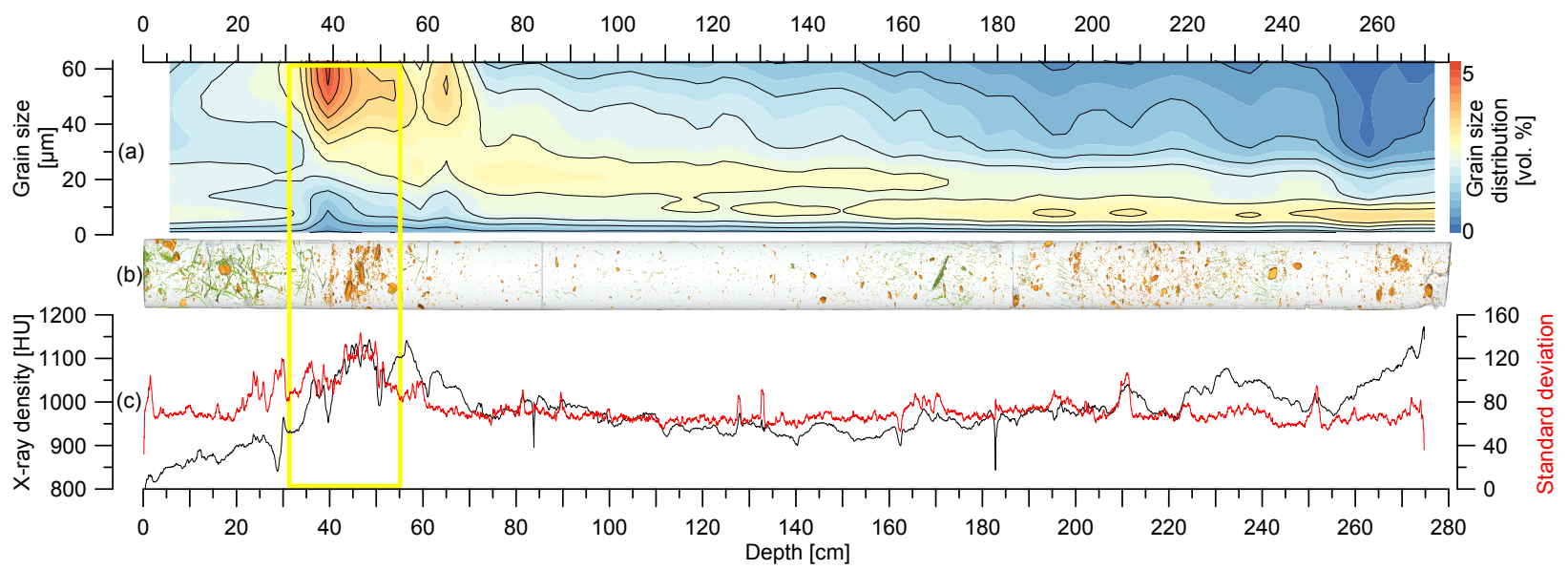

Figure A2. (a) Grain size distribution of fine siliciclastic sediments $(0-63 \mu \mathrm{m})$. (b) Interpreted CT analysis showing bioturbation (green) and clasts (orange). (c) X-ray density (black line) in Hounsfield units (HU) with standard deviation (red line) derived from CT analysis. Yellow rectangle marks disturbed section. Note coarsening upwards of fine sediments (a), high accumulation of clasts (b) and increased $\mathrm{X}$-ray density, as well as respective standard deviation (c) in the disturbed section.

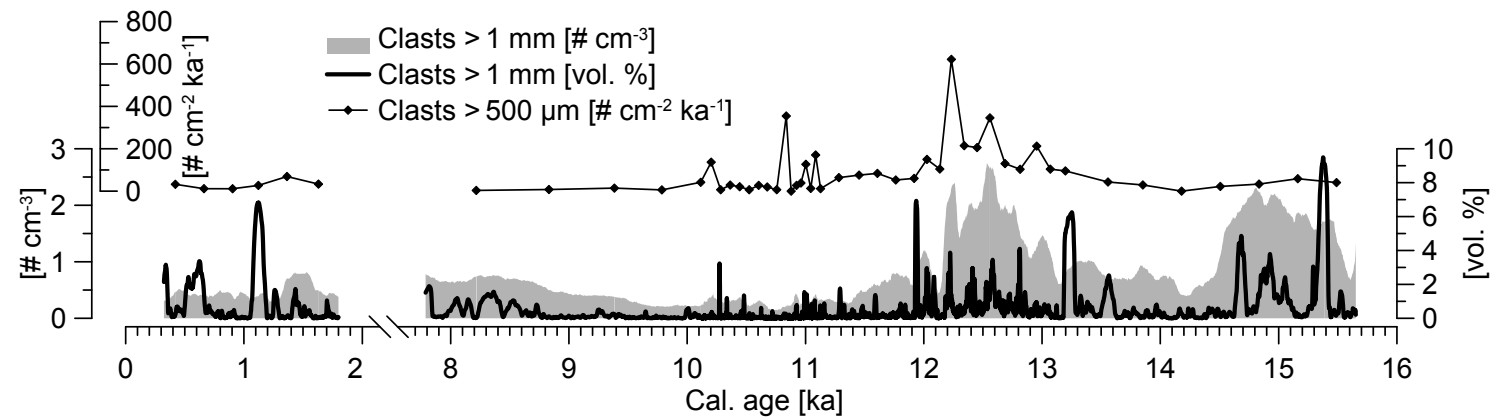

Figure A3. Comparison of methods to determine the input of ice-rafted debris (IRD): accumulation rates (Ehrmann and Thiede, 1985) of clasts $>500 \mu \mathrm{m}$ based on count data as well as volume percentages and numbers of clasts $(>1 \mathrm{~mm}) \mathrm{cm}^{-3}$ based on CT analyses. 


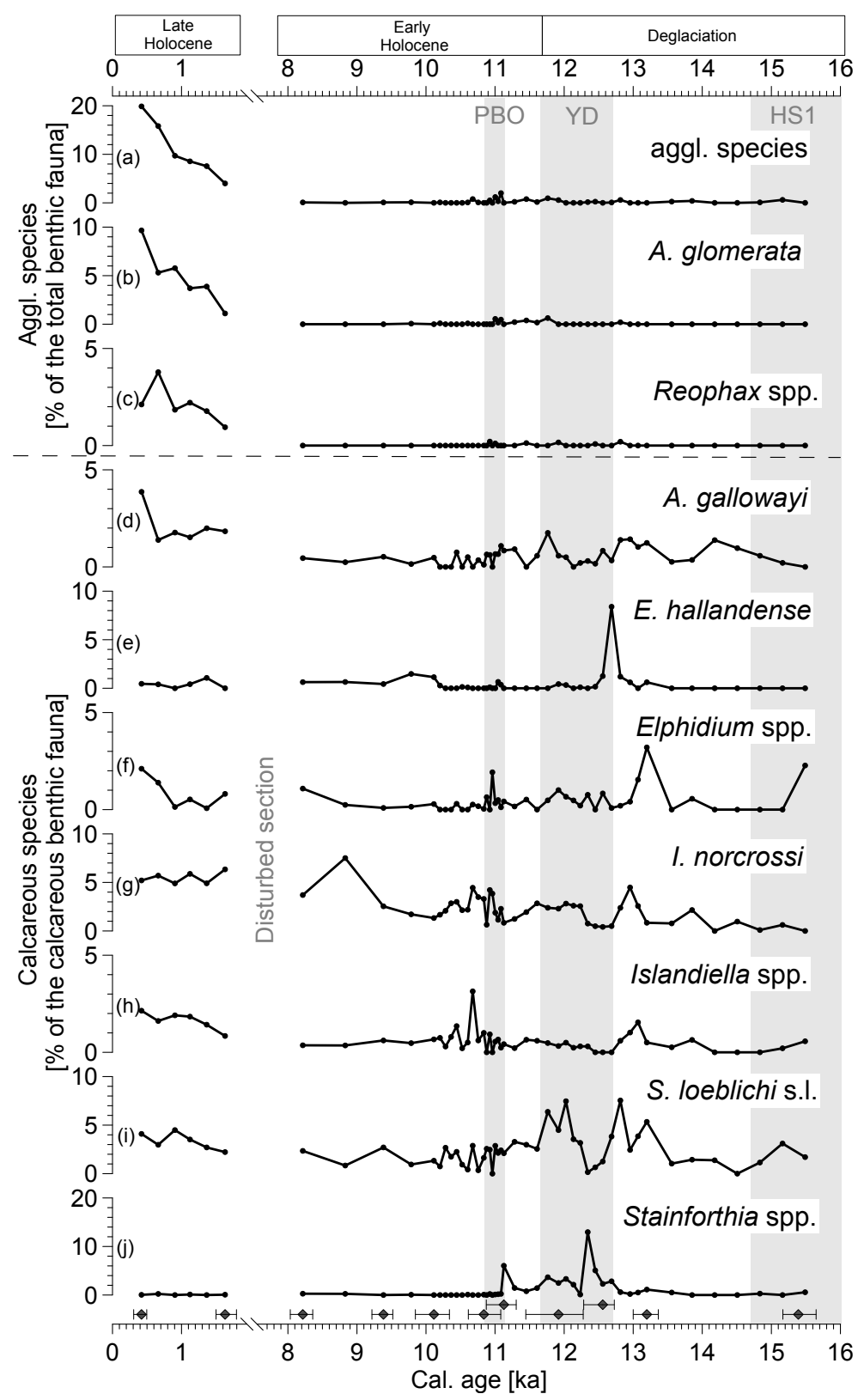

Figure A4. Relative percentages of the total benthic foraminiferal fauna: (a) sum of agglutinating species. (b) Adercotryma glomerata. (c) Reophax spp. Relative percentages of the calcareous benthic foraminiferal fauna: (d) Astrononion gallowayi, (e) Elphidium hallandense, (f) Elphidium spp. (excluding E. asklundi, E. bartletti, E. clavatum, E. hallandense), (g) Islandiella norcrossi, (h) Islandiella spp. (excluding I. helenae, I. islandica, I. norcrossi), (i) Stainforthia loeblichi s.l. and (j) Stainforthia spp. (excluding S. loeblichi s.1.). Grey vertical shadings; see Fig. 4. Dark grey diamonds: calibrated radiocarbon ages with error ranges.

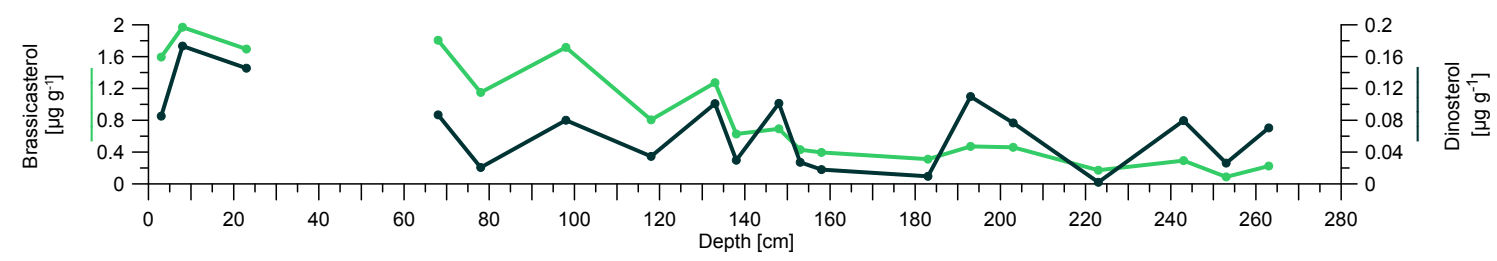

Figure A5. Phytoplankton biomarker ( $\mu \mathrm{g} \mathrm{g}^{-1}$ sediment): brassicasterol (light green line) and dinosterol (dark green line). Note almost parallel trend with brassicasterol showing values 1 magnitude higher than dinosterol. 
Author contributions. MB and DH designed the study. MB performed the faunal analyses, created the figures and interpreted all data. JT created the base maps in Fig. 1b, c and performed the particle size measurements and $\mathrm{CT}$ analyses as well as respective data processing. KF carried out the biomarker analyses. MSS revised the identification of the foraminiferal species and contributed to their interpretation. DH, CHM and RS contributed significantly to the discussion of the data. MB prepared the paper with contributions from all co-authors.

Competing interests. The authors declare that they have no conflict of interest.

Acknowledgements. This project was supported by the Deutsche Forschungsgemeinschaft (DFG) through the International Research Training Group "Processes and impacts of climate change in the North Atlantic Ocean and the Canadian Arctic" (IRTG 1904 ArcTrain). We would like to thank the captain and crew of RV Maria S. Merian as well as the scientists on-board during the cruise MSM02/03 in 2006 for retrieving the samples. The following persons are acknowledged for carrying out measurements: Janet Rethemeyer, University of Cologne, and Lukas Wacker, ETH (Zürich), for radiocarbon measurements as well as Birgit Meyer and Henning Kuhnert, MARUM (Bremen), for stable isotope measurements, and Walter Luttmer, AWI (Bremerhaven), for technical assistance. Further, we thank Hyunyung Boo, McGill University (Montreal), as well as Nele Lamping, Jan Unverfärth and Marco Wolsza, MARUM (Bremen), for sample processing. Sample material was provided by the GeoB repository at MARUM, Bremen. Klinikum Bremen-Mitte is gratefully acknowledged for providing their facilities for the computed tomographies. Arne-Jörn Lemke and Christian Timann, Gesundheit Nord (Bremen), are thanked for performing the CT scans and their support during the measurements. The authors also thank the Editor and two anonymous reviewers for improving the paper with comments and suggestions.

The article processing charges for this open-access publication were covered by the University of Bremen.

Edited by: Arne Winguth

Reviewed by: two anonymous referees

\section{References}

Aagaard, K., Foldvik, A., and Hillman, S. R.: The West Spitsbergen Current: Disposition and water mass transformation, J. Geophys. Res., 92, 3778-3784, https://doi.org/10.1029/JC092iC04p03778, 1987.

Abram, N. J., McGregor, H. V., Tierney, J. E., Evans, M. N., McKay, N. P., Kaufman, D. S., Thirumalai, K., Martrat, B., Goosse, H., Phipps, S. J., Steig, E. J., Kilbourne, K. H., Saenger, C. P., Zinke, J., Leduc, G., Addison, J. A., Mortyn, P. G., Seidenkrantz, M.-S., Sicre, M.-A., Selvaraj, K., Filipsson, H. L., Neukom, R., Gergis, J., Curran, M. A. J., and Gunten, L. von: Early onset of industrial- era warming across the oceans and continents, Nature, 536, 411418, https://doi.org/10.1038/nature19082, 2016.

Ahrens, M. J., Graf, G., and Altenbach, A. V.: Spatial and temporal distribution patterns of benthic foraminifera in the Northeast Water Polynya, Greenland, J. Mar. Syst., 10, 445-465, 1997.

Alley, R. B., Clark, P. U., Huybrechts, P., and Joughin, I.: Ice-Sheet and Sea-Level Changes, Science, 310, 456-460, https://doi.org/10.1126/science.1114613, 2005.

Alve, E. and Bernhard, J. M.: Vertical migratory response of benthic foraminifera to controlled oxygen concentrations in an experimental mesocosm, Mar. Ecol. Prog. Ser., 116, 137-151, 1995.

Arrigo, K. R. and van Dijken, G. L.: Secular trends in Arctic Ocean net primary production, J. Geophys. Res., 116, 60-70, https://doi.org/10.1029/2011JC007151, 2011.

Arrigo, K. R. and van Dijken, G. L.: Continued increases in Arctic Ocean primary production, Prog. Oceanogr., 136, 60-70, https://doi.org/10.1016/j.pocean.2015.05.002, 2015.

Austin, W. E. N., Bard, E., Hunt, J. B., Kroon, D., and Peacock, J. D.: The ${ }^{14} \mathrm{C}$ Age of the Icelandic Vedde Ash: Implications for Younger Dryas Marine Reservoir Age Corrections, Radiocarbon, 37, 53-62, https://doi.org/10.1017/S0033822200014788, 1995.

Austin, W. E. N., Telford, R. J., Ninnemann, U. S., Brown, L., Wilson, L. J., Small, D. P., and Bryant, C. L.: North Atlantic reservoir ages linked to high Younger Dryas atmospheric radiocarbon concentrations, Global Planet. Change, 79, 226-233, https://doi.org/10.1016/j.gloplacha.2011.06.011, 2011.

Baeten, N. J., Forwick, M., Vogt, C., and Vorren, T. O.: Late Weichselian and Holocene sedimentary environments and glacial activity in Billefjorden, Svalbard, in Fjord Systems and Archives, vol. 344, edited by: Austin, W. E. N., Forwick, M., and Paetzel, M., 207-223, Geological Society, London, 2010.

Bakke, J., Lie, Ø., Heegaard, E., Dokken, T., Haug, G. H., Birks, H. H., Dulski, P., and Nilsen, T.: Rapid oceanic and atmospheric changes during the Younger Dryas cold period, Nat. Geosci., 2, 202-205, https://doi.org/10.1038/ngeo439, 2009.

Bard, E., Arnold, M., Mangerud, J., Paterne, M., Labeyrie, L., Duprat, J., Mélières, M.-A., Sønstegaard, E., and Duplessy, J. C.: The North Atlantic atmosphere-sea surface ${ }^{14} \mathrm{C}$ gradient during the Younger Dryas climatic event, Earth Planet. Sc. Lett., 126 275-287, https://doi.org/10.1016/0012-821X(94)90112-0, 1994.

Bartholomaus, T. C., Larsen, C. F., and O'Neel, S.: Does calving matter? Evidence for significant submarine melt, Earth Planet. Sc. Lett., 380, 21-30, https://doi.org/10.1016/j.epsl.2013.08.014, 2013.

Bauch, H. A., Erlenkeuser, H., Spielhagen, R. F., Struck, U., Matthiessen, J., Thiede, J., and Heinemeier, J.: A multiproxy reconstruction of the evolution of deep and surface waters in the subarctic Nordic seas over the last 30,000 yr, Quaternary Sci. Rev., 20, 659-678, https://doi.org/10.1016/S02773791(00)00098-6, 2001.

Belt, S. T. and Müller, J.: The Arctic sea ice biomarker $\mathrm{IP}_{25}$ : A review of current understanding, recommendations for future research and applications in palaeo sea ice reconstructions, Quaternary Sci. Rev., 79, 9-25, https://doi.org/10.1016/j.quascirev.2012.12.001, 2013.

Belt, S. T., Massé, G., Rowland, S. J., Poulin, M., Michel, C., and LeBlanc, B.: A novel chemical fossil of palaeo sea ice: $\mathrm{IP}_{25}$, Org. Geochem., 38, 16-27, https://doi.org/10.1016/j.orggeochem.2006.09.013, 2007. 
Berger, A. and Loutre, M. F.: Insolation values for the climate of the last 10 million years, Quaternary Sci. Rev., 10, 297-317, https://doi.org/10.1016/0277-3791(91)90033-Q, 1991.

Bernhard, J. M. and Bowser, S. S.: Benthic foraminifera of dysoxic sediments: chloroplast sequestration and functional morphology, Earth-Science Rev., 46, 149-165, https://doi.org/10.1016/S00128252(99)00017-3, 1999.

Beszczynska-Möller, A., Woodgate, R., Lee, C., Melling, H., and Karcher, M.: A Synthesis of Exchanges Through the Main Oceanic Gateways to the Arctic Ocean, Oceanography, 24, 8299, https://doi.org/10.5670/oceanog.2011.59, 2011.

Beszczynska-Möller, A., Fahrbach, E., Schauer, U., and Hansen, E.: Variability in Atlantic water temperature and transport at the entrance to the Arctic Ocean, 1997-2010, ICES J. Mar. Sci., 69, 852-863, https://doi.org/10.1093/icesjms/fss056, 2012.

Birgel, D. and Stein, R.: Northern Fram Strait and Yermak Plateau: distribution, variability and burial of organic carbon and paleoenvironmental implications, in The Organic Carbon Cycle in the Arctic Ocean, edited by: Stein, R. and Macdonald, R. W., 279294, Springer, Berlin, 2004.

Björck, S., Kromer, B., Johnsen, S., Bennike, O., Hammarlund, D., Lemdahl, G., Possnert, G., Rasmussen, T. L., Wohlfarth, B., Hammer, C. U., and Spurk, M.: Synchronized Terrestrial-Atmospheric Deglacial Records Around the North Atlantic, Science, 274, 1155-1160, https://doi.org/10.1126/science.274.5290.1155, 1996.

Björck, S., Rundgren, M., Ingólfsson, Ó., and Funder, S.: The Preboreal oscillation around the Nordic Seas: terrestrial and lacustrine responses, J. Quat. Sci., 12, 455-465, https://doi.org/10.1002/(SICI)10991417(199711/12)12:6<455::AID-JQS316>3.0.CO;2-S, 1997.

Björck, S., Bennike, O., Rosén, P., Andresen, C. S., Bohncke, S., Kaas, E., and Conley, D.: Anomalously mild Younger Dryas summer conditions in southern Greenland, Geology, 30, 427-430, https://doi.org/10.1130/00917613(2002)030<0427:AMYDSC>2.0.CO;2, 2002.

Błaszczyk, M., Jania, J. A., and Hagen, J. O.: Tidewater glaciers of Svalbard: Recent changes and estimates of calving fluxes, Polish Polar Res., 30, 85-142, 2009.

Bonnet, S., de Vernal, A., Hillaire-Marcel, C., Radi, T., and Husum, K.: Variability of sea-surface temperature and sea-ice cover in the Fram Strait over the last two millennia, Mar. Micropaleontol., 74, 59-74, https://doi.org/10.1016/j.marmicro.2009.12.001, 2010.

Boulton, G.: Glacial history of the Spitsbergen archipelago and the problem of a Barents Shelf ice sheet, Boreas, 8, 31-57, https://doi.org/10.1111/j.1502-3885.1979.tb00429.x, 1979.

Brassell, S. C., Eglinton, G., Marlowe, I. T., Pflaumann, U., and Sarnthein, M.: Molecular stratigraphy: a new tool for climatic assessment, Nature, 320, 129-133, https://doi.org/10.1038/320129a0, 1986.

Broecker, W. S.: Was the Younger Dryas triggered by a flood?, Science, 312, 1146-1148, https://doi.org/10.1126/science.1123253, 2006.

Broecker, W. S., Kennett, J. P., Flower, B. P., Teller, J. T., Trumbore, S., Bonani, G., and Wolfli, W.: Routing of meltwater from the Laurentide Ice Sheet during the Younger Dryas cold episode, Nature, 341, 318-321, https://doi.org/10.1038/341318a0, 1989.

Bromley, G. R., Putnam, A. E., Rademaker, K. M., Lowell, T. V, Schaefer, J. M., Hall, B., Winckler, G., Birkel, S. D., and
Borns, H. W.: Younger Dryas deglaciation of Scotland driven by warming summers, Proc. Natl. Acad. Sci. USA, 111, 6215-6219, https://doi.org/10.1073/pnas.1321122111, 2014.

Brückner, H. and Schellmann, G.: Late Pleistocene and Holocene Shorelines of Andréeland, Spitsbergen (Svalbard) - Geomorphological Evidence and Palaeo-Oceanographic Significance, J. Coast. Res., 19, 971-982, 2003.

Cabedo-Sanz, P., Belt, S. T., Knies, J., and Husum, K.: Identification of contrasting seasonal sea ice conditions during the Younger Dryas, Quaternary Sci. Rev., 79, 74-86, https://doi.org/10.1016/j.quascirev.2012.10.028, 2013.

Carbonara, K., Mezgec, K., Varagona, G., Musco, M. E., Lucchi, R. G., Villa, G., Morigi, C., Melis, R., and Caffau, M.: Palaeoclimatic changes in Kveithola, Svalbard, during the Late Pleistocene deglaciation and Holocene: Evidences from microfossil and sedimentary records, Palaeogeogr. Palaeocl., 463, 136-149, https://doi.org/10.1016/j.palaeo.2016.10.003, 2016.

Carmack, E. and Wassmann, P.: Food webs and physicalbiological coupling on pan-Arctic shelves: Unifying concepts and comprehensive perspectives, Prog. Oceanogr., 71, 446-477, https://doi.org/10.1016/j.pocean.2006.10.004, 2006.

Cedhagen, T.: Retention of chloroplasts and bathymetric distribution in the Sublittoral Foraminiferan Nonionellina Labradorica, Ophelia, 33, 17-30, https://doi.org/10.1080/00785326.1991.10429739, 1991.

Chauhan, T., Rasmussen, T. L., Noormets, R., Jakobsson, M., and Hogan, K. A.: Glacial history and paleoceanography of the southern Yermak Plateau since 132 ka BP, Quaternary Sci. Rev., 92, 155-169, https://doi.org/10.1016/j.quascirev.2013.10.023, 2014.

Chauhan, T., Rasmussen, T. L., and Noormets, R.: Palaeoceanography of the Barents Sea continental margin, north of Nordaustlandet, Svalbard, during the last $74 \mathrm{ka}$, Boreas, 45, 76-99, https://doi.org/10.1111/bor.12135, 2015.

Cohen, J.: An observational analysis: Tropical relative to Arctic influence on midlatitude weather in the era of Arctic amplification, Geophys. Res. Lett., 43, 5287-5294, https://doi.org/10.1002/2016GL069102, 2016.

Cohen, J., Screen, J. A., Furtado, J. C., Barlow, M., Whittleston, D., Coumou, D., Francis, J., Dethloff, K., Entekhabi, D., Overland, J., and Jones, J.: Recent Arctic amplification and extreme mid-latitude weather, Nat. Geosci., 7, 627-637, https://doi.org/10.1038/ngeo2234, 2014.

Cook, A. J., Holland, P. R., Meredith, M. P., Murray, T., Luckman, A., and Vaughan, D. G.: Ocean forcing of glacier retreat in the western Antarctic Peninsula, Science, 353, 283-286, https://doi.org/10.1126/science.aae0017, 2016.

Cottier, F., Tverberg, V., Inall, M., Svendsen, H., Nilsen, F., and Griffiths, C.: Water mass modification in an Arctic fjord through cross-shelf exchange: The seasonal hydrography of Kongsfjorden, Svalbard, J. Geophys. Res., 110, C12005, https://doi.org/10.1029/2004JC002757, 2005.

Cottier, F. R., Nilsen, F., Inall, M. E., Gerland, S., Tverberg, V., and Svendsen, H.: Wintertime warming of an Arctic shelf in response to large-scale atmospheric circulation, Geophys. Res. Lett., 34, L10607, https://doi.org/10.1029/2007GL029948, 2007.

Cottier, F. R., Nilsen, F., Skogseth, R., Tverberg, V., Skarðhamar, J., and Svendsen, H.: Arctic fjords: a review of the oceanographic environment and dominant physical processes, in Fjord Systems 
and Archives, vol. 344, edited by: Howe, J. A., Austin, W. E. N., Forwick, M., and Paetzel, M., 35-50, Geological Society, London, 2010.

D’Andrea, W. J., Vaillencourt, D. A., Balascio, N. L., Werner, A., Roof, S. R., Retelle, M., and Bradley, R. S.: Mild Little Ice Age and unprecedented recent warmth in an 1800 year lake sediment record from Svalbard, Geology, 40, 1007-1010, https://doi.org/10.1130/G33365.1, 2012.

Darling, K. F., Schweizer, M., Knudsen, K. L., Evans, K. M., Bird, C., Roberts, A., Filipsson, H. L., Kim, J.-H., Gudmundsson, G., Wade, C. M., Sayer, M. D. J., and Austin, W. E. N.: The genetic diversity, phylogeography and morphology of Elphidiidae (Foraminifera) in the Northeast Atlantic, Mar. Micropaleontol., 129, 1-23, https://doi.org/10.1016/j.marmicro.2016.09.001, 2016.

Dubicka, Z., Złotnik, M., and Borszcz, T.: Test morphology as a function of behavioral strategies - Inferences from benthic foraminifera, Mar. Micropaleontol., 116, 38-49, https://doi.org/10.1016/j.marmicro.2015.01.003, 2015.

Duplessy, J. C., Cortijo, E., Ivanova, E., Khusid, T., Labeyrie, L., Levitan, M., Murdmaa, I., and Paterne, M.: Paleoceanography of the Barents Sea during the Holocene, Paleoceanography, 20, PA4004, https://doi.org/10.1029/2004PA001116, 2005.

Ehrmann, W. and Thiede, J.: History of Mezozoic and Cenozoic sediment fluxes to the North Atlantic Ocean, Contrib. Sedimentol., 15, 1-109, 1985.

Fahl, K. and Stein, R.: Biomarkers as organic-carbon-source and environmental indicators in the late quaternary Arctic Ocean: Problems and perspectives, Mar. Chem., 63, 293-309, https://doi.org/10.1016/S0304-4203(98)00068-1, 1999.

Fahl, K. and Stein, R.: Modern seasonal variability and deglacial/Holocene change of central Arctic Ocean sea-ice cover: New insights from biomarker proxy records, Earth Planet. Sc. Lett., 351-352, 123-133, https://doi.org/10.1016/j.epsl.2012.07.009, 2012.

Falk-Petersen, S., Pavlov, V., Berge, J., Cottier, F., Kovacs, K. M., and Lydersen, C.: At the rainbow's end: high productivity fueled by winter upwelling along an Arctic shelf, Polar Biol., 38, 5-11, https://doi.org/10.1007/s00300-014-1482-1, 2015.

Fisher, T. G., Smith, D. G., and Andrews, J. T.: Preboreal oscillation caused by a glacial Lake Agassiz flood, Quaternary Sci. Rev., 21, 873-878, https://doi.org/10.1016/S0277-3791(01)00148-2, 2002.

Forman, S. L., Lubinski, D. J., Ingólfsson, Ó., Zeeberg, J. J., Snyder, J. A., Siegert, M. J., and Matishov, G. G.: A review of postglacial emergence on Svalbard, Franz Josef Land and Novaya Zemlya, northern Eurasia, Quaternary Sci. Rev., 23, 1391-1434, https://doi.org/10.1016/j.quascirev.2003.12.007, 2004.

Forwick, M.: Sedimentary processes and palaeoenvironments in Spitsbergen fjords, $\mathrm{PhD}$ thesis, 2005.

Forwick, M., Vorren, T. O., Hald, M., Korsun, S., Roh, Y., Vogt, C., and Yoo, K.-C.: Spatial and temporal influence of glaciers and rivers on the sedimentary environment in Sassenfjorden and Tempelfjorden, Spitsbergen, in Fjord Systems and Archives, vol. 344, edited by: Howe, J. A., Austin, W. E. N., Forwick, M., and Paetzel, M., 163-193, Geological Society, London, 2010.

Furrer, G., Stapfer, A., and Glaser, U.: Zur nacheiszeitlichen Gletschergeschichte des Liefdefjords (Spitzbergen) (Ergebnisse der Geowissenschaftlichen Spitzbergenexpedition 1990), Geogr.
Helv., 46, 147-155, https://doi.org/10.5194/gh-46-147-1991, 1991.

Gjermundsen, E. F., Briner, J. P., Akçar, N., Salvigsen, O., Kubik, P., Gantert, N., and Hormes, A.: Late Weichselian local ice dome configuration and chronology in Northwestern Svalbard: early thinning, late retreat, Quaternary Sci. Rev., 72, 112-127, https://doi.org/10.1016/j.quascirev.2013.04.006, 2013.

Gregory, J. M. and Huybrechts, P.: Ice-sheet contributions to future sea-level change, Philos. Trans. R. Soc. A Math. Phys. Eng. Sci., 364, 1709-1732, https://doi.org/10.1098/rsta.2006.1796, 2006.

Groot, D. E., Aagaard-Sørensen, S., and Husum, K.: Reconstruction of Atlantic water variability during the Holocene in the western Barents Sea, Clim. Past, 10, 51-62, https://doi.org/10.5194/cp10-51-2014, 2014.

Gump, D. J., Briner, J. P., Mangerud, J., and Svendsen, J. I.: Deglaciation of Boknafjorden, south-western Norway, J. Quat Sci., 32, 80-90, https://doi.org/10.1002/jqs.2925, 2017.

Hagen, J. O., Listøl, O., Roland, E., and Jørgensen, T.: Glacier Atlas of Svalbard and Jan Mayen, edited by: Brekke, A., Norsk Polarinstitutt, Oslo, 167 pp., 1993.

Haine, T. W. N., Curry, B., Gerdes, R., Hansen, E., Karcher, M., Lee, C., Rudels, B., Spreen, G., De Steur, L., Stewart, K. D., and Woodgate, R.: Arctic freshwater export: Status, mechanisms, and prospects, Global Planet. Change, 125, 13-35, https://doi.org/10.1016/j.gloplacha.2014.11.013, 2015.

Hald, M. and Hagen, S.: Early Preboreal cooling in the Nordic seas region triggered by meltwater, Geology, 26, 615-618, https://doi.org/10.1130/00917613(1998)026<0615:EPCITN>2.3.CO, 1998.

Hald, M. and Korsun, S.: Distribution of modern benthic foraminifera from fjords of Svalbard, European Arctic, J. Foraminifer. Res., 27, 101-122, https://doi.org/10.2113/gsjfr.27.2.101, 1997.

Hald, M. and Steinsund, P. I.: Benthic foraminifera and carbonate dissolution in the surface sediments of the Barents and Kara Sea, in Surface Sediment Composition and Sedimentary Processes in the Central Arctic and along the Eurasian Continental Margin, edited by: Stein, R., Ivanov, G. I., Levitan, M. A., and Fahl, K., 285-307, Bremerhaven, 1996.

Hald, M., Ebbesen, H., Forwick, M., Godtliebsen, F., Khomenko, L., Korsun, S., Ringstad Olsen, L., and Vorren, T. O.: Holocene paleoceanography and glacial history of the West Spitsbergen area, Euro-Arctic margin, Quaternary Sci. Rev., 23, 2075-2088, https://doi.org/10.1016/j.quascirev.2004.08.006, 2004.

Hall, B., Baroni, C., Denton, G., Kelly, M. A., and Lowell, T.: Relative sea-level change, Kjove Land, Scoresby Sund, East Greenland: implications for seasonality in Younger Dryas time, Quaternary Sci. Rev., 27, 2283-2291, https://doi.org/10.1016/j.quascirev.2008.08.001, 2008.

Hansen, A. and Knudsen, K. L.: Recent foraminiferal distribution in Freemansundet and early Holocene stratigraphy on Edgeoya, Svalbard, Polar Res., 14, 215-238, https://doi.org/10.1111/j.1751-8369.1995.tb00690.x, 1995.

Hanslik, D., Jakobsson, M., Backman, J., Björck, S., Sellén, E., O’Regan, M., Fornaciari, E., and Skog, G.: Quaternary Arctic Ocean sea ice variations and radiocarbon reservoir age corrections, Quaternary Sci. Rev., 29, 3430-3441, https://doi.org/10.1016/j.quascirev.2010.06.011, 2010. 
Harland, W. B.: The Geology of Svalbard, Memoir 17, Geological Society, London, 521 pp., 1998.

Hattermann, T., Isachsen, P. E., von Appen, W.-J. J., Albretsen, J., and Sundfjord, A.: Eddy-driven recirculation of Atlantic Water in Fram Strait, Geophys. Res. Lett., 43, 3406-3414, https://doi.org/10.1002/2016GL068323, 2016.

Hebbeln, D.: Flux of ice-rafted detritus from sea ice in the Fram Strait, Deep Sea Res. Part II Top. Stud. Oceanogr., 47, 17731790, https://doi.org/10.1016/S0967-0645(00)00006-0, 2000.

Holland, D. M., Thomas, R. H., de Young, B., Ribergaard, M. H., and Lyberth, B.: Acceleration of Jakobshavn Isbræ triggered by warm subsurface ocean waters, Nat. Geosci., 1, 659-664, https://doi.org/10.1038/ngeo316, 2008.

Hormes, A., Gjermundsen, E. F., and Rasmussen, T. L.: From mountain top to the deep sea - Deglaciation in 4D of the northwestern Barents Sea ice sheet, Quaternary Sci. Rev., 75, 78-99, https://doi.org/10.1016/j.quascirev.2013.04.009, 2013.

Hughes, A. L. C., Gyllencreutz, R., Lohne, Ø. S., Mangerud, J., and Svendsen, J. I.: The last Eurasian ice sheets - a chronological database and time-slice reconstruction, DATED-1, Boreas, 45, 1-45, https://doi.org/10.1111/bor.12142, 2016.

Humlum, O., Elberling, B., Hormes, A., Fjordheim, K., Hansen, O. H., and Heinemeier, J.: Late-Holocene glacier growth in Svalbard, documented by subglacial relict vegetation and living soil microbes, The Holocene, 15, 396-407, https://doi.org/10.1191/0959683605hl817rp, 2005.

Hunt, G. L., Drinkwater, K. F., Arrigo, K., Berge, J., Daly, K. L., Danielson, S., Daase, M., Hop, H., Isla, E., Karnovsky, N., Laidre, K., Mueter, F. J., Murphy, E. J., Renaud, P. E., Smith, W. O., Trathan, P., Turner, J., and Wolf-Gladrow, D.: Advection in polar and sub-polar environments: Impacts on high latitude marine ecosystems, Prog. Oceanogr., 149, 40-81, https://doi.org/10.1016/j.pocean.2016.10.004, 2016.

Inall, M. E., Murray, T., Cottier, F. R., Scharrer, K., Boyd, T. J., Heywood, K. J., and Bevan, S. L.: Oceanic heat delivery via Kangerdlugssuaq Fjord to the south-east Greenland ice sheet, J. Geophys. Res.-Ocean., 119, 631-645, https://doi.org/10.1002/2013JC009295, 2014.

IPCC: Contribution of Working Groups I, II and III to the Fifth Assessment Report of the Intergovernmental Panel on Climate Change, edited by: Pachauri, R. K. and Meyer, L. A., IPCC, Geneva, 2014.

Jennings, A. E. and Helgadottir, G.: Foraminiferal Assemblages From the Fjords and Shelf of Eastern Greenland, J. Foraminifer. Res., 24, 123-144, https://doi.org/10.2113/gsjfr.24.2.123, 1994.

Jennings, A. E., Weiner, N. J., Helgadottir, G., and Andrews, J. T.: Modern foraminiferal faunas of the southwestern to northern Iceland Shelf: Oceanographic and environmental controls, J. Foraminifer. Res., 34, 180-207, https://doi.org/10.2113/34.3.180, 2004.

Jennings, A. E., Hald, M., Smith, M., and Andrews, J. T.: Freshwater forcing from the Greenland Ice Sheet during the Younger Dryas: Evidence from southeastern Greenland shelf cores, Quaternary Sci. Rev., 25, 282-298, https://doi.org/10.1016/j.quascirev.2005.04.006, 2006.

Jernas, P., Klitgaard Kristensen, D., Husum, K., Wilson, L., and Koç, N.: Palaeoenvironmental changes of the last two millennia on the western and northern Svalbard shelf, Boreas, 42, 236-255, https://doi.org/10.1111/j.1502-3885.2012.00293.x, 2013.
Jessen, S. P., Rasmussen, T. L., Nielsen, T., and Solheim, A.: A new Late Weichselian and Holocene marine chronology for the western Svalbard slope 30,000-0 cal years BP, Quaternary Sci. Rev., 29, 1301-1312, https://doi.org/10.1016/j.quascirev.2010.02.020, 2010.

Johannessen, O. M.: Brief overview of the physical oceanography, in The Nordic Seas, edited by: Hurdle, B. G., 103-127, Springer, New York, 1986.

Klitgaard Kristensen, D., Rasmussen, T. L., and Koç, N.: Palaeoceanographic changes in the northern Barents Sea during the last 16000 years - new constraints on the last deglaciation of the Svalbard-Barents Sea Ice Sheet, Boreas, 42, 798-813, https://doi.org/10.1111/j.1502-3885.2012.00307.x, 2013.

Koç, N., Klitgaard-Kristensen, D., Hasle, K., Forsberg, C. F., and Solheim, A.: Late glacial palaeoceanography of Hinlopen Strait, northern Svalbard, Polar Res., 21, 307-314, https://doi.org/10.1111/j.1751-8369.2002.tb00085.x, 2002.

Kohler, J., James, T. D., Murray, T., Nuth, C., Brandt, O., Barrand, N. E., Aas, H. F., and Luckman, A.: Acceleration in thinning rate on western Svalbard glaciers, Geophys. Res. Lett., 34, L18502, https://doi.org/10.1029/2007GL030681, 2007.

Korsun, S. and Hald, M.: Modern Benthic Foraminifera off Novaya Zemlya Tidewater Glaciers, Russian Arctic, Arct. Alp. Res., 30, 61-77, https://doi.org/10.2307/1551746, 1998.

Korsun, S. and Hald, M.: Seasonal Dynamics of Benthic Foraminifera in a Glacially Fed Fjord of Svalbard, European Arctic, J. Foraminifer. Res., 30, 251-271, https://doi.org/10.2113/0300251, 2000.

Kubischta, F., Knudsen, K. L., Ojala, A. E. K., and Salonen, V.-P.: Holocene benthic foraminiferal record from a high-Arctic fjord, Nordaustlandet, Svalbard, Geogr. Ann. Ser. A, Phys. Geogr., 93, 227-242, https://doi.org/10.1111/j.1468-0459.2011.00434.x, 2011.

Kug, J., Jeong, J., Jang, Y., Kim, B., Folland, C. K., Min, S., and Son, S.: Two distinct influences of Arctic warming on cold winters over North America and East Asia, Nat. Geosci., 8, 759-763, https://doi.org/10.1038/NGEO2517, 2015.

Łącka, M., Zajączkowski, M., Forwick, M., and Szczuciński, W.: Late Weichselian and Holocene palaeoceanography of Storfjordrenna, southern Svalbard, Clim. Past, 11, 587-603, https://doi.org/10.5194/cp-11-587-2015, 2015.

Landvik, J. Y., Bondevik, S., Elverhøi, A., Fjeldskaar, W., Mangerud, J., Salvigsen, O., Siegert, M. J., Svendsen, J. I., and Vorren, T. O.: The last glacial maximum of Svalbard and the Barents Sea area: Ice sheet extent and configuration, Quaternary Sci. Rev., 17, 43-75, https://doi.org/10.1016/S0277-3791(97)000668, 1998.

Lane, C. S., Brauer, A., Blockley, S. P. E., and Dulski, P.: Volcanic ash reveals time-transgressive abrupt climate change during the Younger Dryas, Geology, 41, 1251-1254, https://doi.org/10.1130/G34867.1, 2013.

Lherminier, P., Meincke, J., Freiwald, A., and Schauer, U. (Eds.): Circulation and Ecosystems in the Subpolar and Cruise Polar North Atlantic, Cruise No. 2, 23 May-16 September 2006, Maria S. Merian-Berichte 09-1, 174 pp., https://www.tib.eu/de/ suchen/id/awi\%3Adoi 10.2312\%252Fr_msm02/ (last access: 23 November 2017), 2009. 
Lind, S. and Ingvaldsen, R. B.: Variability and impacts of Atlantic Water entering the Barents Sea from the north, Deep.-Sea Res. Pt. I, 62, 70-88, https://doi.org/10.1016/j.dsr.2011.12.007, 2012.

Locarnini, R. A., Mishonov, A. V., Antonov, J. I., Boyer, T. P., Garcia, H. E., Baranova, O. K., Zweng, M. M., Paver, C. R., Reagan, J. R., Johnson, D. R., Hamilton, M., and Seidov, D.: World Ocean Atlas 2013 Volume 1: Temperature, edited by S. Levitus (Ed.) and A. Mishonov (technical Ed.), NOAA Atlas NESDIS 73, 2013.

Loeng, H.: Features of the physical oceanographic conditions of the Barents Sea, Polar Res., 10, 5-18, 1991.

Loubere, P. and Rayray, S.: Benthic foraminiferal assemblage formation: Theory and observation for the European Arctic margin, Deep Sea Res. Pt. I, 115, 36-47, https://doi.org/10.1016/j.dsr.2016.05.004, 2016.

Lubinski, D. J., Polyak, L., and Forman, S. L.: Freshwater and Atlantic water inflows to the deep northern Barents and Kara seas since ca $13{ }^{14} \mathrm{C} \mathrm{ka}$ : foraminifera and stable isotopes, Quaternary Sci. Rev., 20, 1851-1879, https://doi.org/10.1016/S02773791(01)00016-6, 2001.

Luckman, A., Benn, D. I., Cottier, F., Bevan, S., Nilsen, F., and Inall, M.: Calving rates at tidewater glaciers vary strongly with ocean temperature, Nat. Commun., 6, 8566, https://doi.org/10.1038/ncomms9566, 2015.

Mackensen, A.: On the use of benthic foraminiferal ${ }^{13} \mathrm{C}$ in palaeoceanography: constraints from primary proxy relationships, in Biogeochemical Controls on Palaeoceanographic Environmental Proxies, vol. 303, edited by: Austin, W. E. N. and James, R. H., 121-133, Geological Society, London, 2008.

Mackensen, A. and Schmiedl, G.: Brine formation recorded by stable isotopes of Recent benthic foraminifera in Storfjorden, Svalbard: palaeoceanographical implications, Boreas, 45, 552-566, https://doi.org/10.1111/bor.12174, 2016.

Mackensen, A., Sejrup, H.-P. P., and Jansen, E.: The distribution of living benthic foraminifera on the continental slope and rise off Southwest Norway, Mar. Micropaleontol., 9, 275-306, https://doi.org/10.1017/CBO9781107415324.004, 1985.

Mackensen, A., Schmiedl, G., Thiele, J., and Damm, E.: Microhabitat preferences of live benthic foraminifera and stable carbon isotopes off SW Svalbard in the presence of widespread methane seepage, Mar. Micropaleontol., 132, 1-17, https://doi.org/10.1016/j.marmicro.2017.04.004, 2017.

Majewski, W., Szczuciński, W., and Zajączkowski, M.: Interactions of Arctic and Atlantic water-masses and associated environmental changes during the last millennium, Hornsund (SW Svalbard), Boreas, 38, 529-544, https://doi.org/10.1111/j.15023885.2009.00091.x, 2009.

Mangerud, J.: Radiocarbon dating of marine shells including a discussion of the apparent age of recent shells from Norway, Boreas, 1, 143-172, https://doi.org/10.1111/j.15023885.1972.tb00147.x, 1972.

Mangerud, J. and Gulliksen, S.: Apparent radiocarbon ages of recent marine shells from Norway, Spitsbergen, and Arctic Canada, Quat. Res., 5, 263-273, https://doi.org/10.1016/00335894(75)90028-9, 1975.

Mangerud, J. and Landvik, J. Y.: Younger Dryas cirque glaciers in western Spitsbergen: smaller than during the Little Ice Age, Boreas, 36, 278-285, https://doi.org/10.1080/03009480601134827, 2007.
Manley, T. O.: Branching of Atlantic Water within the GreenlandSpitsbergen Passage: An estimate of recirculation, J. Geophys Res., 100, 20627, https://doi.org/10.1029/95JC01251, 1995.

Marchal, O., Cacho, I., Stocker, T. F., Grimalt, J. O., Calvo, E., Martrat, B., Shackleton, N., Vautravers, M., Cortijo, E., Kreveld, S. Van, Andersson, C., Koç, N., Chapman, M., Sbaffi, L., Duplessy, J., Sarnthein, M., Turon, J., Duprat, J., and Jansen, E.: Apparent long-term cooling of the sea surface in the northeast Atlantic and Mediterranean during the Holocene, Quaternary Sci. Rev., 21, 455-483, https://doi.org/10.1016/S02773791(01)00105-6, 2002.

Masson-Delmotte, V., Schulz, M., Abe-Ouchi, A., Beer, J., Ganopolski, A., González Rouco, J. F., Jansen, E., Lambeck, K., Luterbacher, J., Naish, T., Osborn, T., Otto-Bliesner, B., Quinn, T., Ramesh, R., Rojas, M., Shao, X., Timmermann, A., and Rouco, J. F. G.: Information from Paleoclimate Archives, in Climate Change 2013: The Physical Science Basis, Contribution of Working Group I to the Fifth Assessment Report of the Intergovernmental Panel on Climate Change, edited by: Stocker, T. F., Qin, D., Plattner, G.-K., Tignor, M., Allen, S. K., Boschung, J., Nauels, A., Xia, Y., Bex, V., and Midgley, P. M., 383-464, Cambridge University Press, Cambridge, 2013.

McCusker, K. E., Fyfe, J. C., and Sigmond, M.: Twenty-five winters of unexpected Eurasian cooling unlikely due to Arctic seaice loss, Nat. Geosci., 9, 5-10, https://doi.org/10.1038/ngeo2820, 2016.

McGregor, H. V., Dupont, L., Stuut, J. B. W., and Kuhlmann, H.: Vegetation change, goats, and religion: a 2000-year history of land use in southern Morocco, Quaternary Sci. Rev., 28, 14341448, https://doi.org/10.1016/j.quascirev.2009.02.012, 2009.

Meleshko, V. P., Johannessen, O. M., Baidin, A. V., Pavlova, T. V., and Govorkova, V. A.: Arctic amplification: does it impact the polar jet stream?, Tellus A, 68, 1-11, https://doi.org/10.3402/tellusa.v68.32330, 2016.

Miller, G. H., Brigham-Grette, J., Alley, R. B., Anderson, L., Bauch, H. A., Douglas, M. S. V., Edwards, M. E., Elias, S. a., Finney, B. P., Fitzpatrick, J. J., Funder, S. V., Herbert, T. D., Hinzman, L. D., Kaufman, D. S., MacDonald, G. M., Polyak, L., Robock, A., Serreze, M. C., Smol, J. P., Spielhagen, R., White, J. W. C., Wolfe, A. P., and Wolff, E. W.: Temperature and precipitation history of the Arctic, Quaternary Sci. Rev., 29, 1679-1715, https://doi.org/10.1016/j.quascirev.2010.03.001, 2010.

Mori, M., Watanabe, M., Shiogama, H., Inoue, J., and Kimoto, M.: Robust Arctic sea-ice influence on the frequent Eurasian cold winters in past decades, Nat. Geosci., 7, 869-874, https://doi.org/10.1038/ngeo2277, 2014.

Motyka, R. J., Hunter, L., Echelmeyer, K. A., and Connor, C.: Submarine melting at the terminus of a temperate tidewater glacier, LeConte Glacier, Alaska, U.S.A., Ann. Glaciol., 36, 5765, https://doi.org/10.3189/172756403781816374, 2003.

Müller, J. and Stein, R.: High-resolution record of late glacial and deglacial sea ice changes in Fram Strait corroborates ice-ocean interactions during abrupt climate shifts, Earth Planet. Sc. Lett., 403, 446-455, https://doi.org/10.1016/j.epsl.2014.07.016, 2014.

Müller, J., Wagner, A., Fahl, K., Stein, R., Prange, M., and Lohmann, G.: Towards quantitative sea ice reconstructions in the northern North Atlantic: A combined biomarker and numerical modelling approach, Earth Planet. Sc. Lett., 306, 137-148, https://doi.org/10.1016/j.eps1.2011.04.011, 2011. 
Müller, J., Werner, K., Stein, R., Fahl, K., Moros, M., and Jansen, E.: Holocene cooling culminates in sea ice oscillations in Fram Strait, Quaternary Sci. Rev., 47, 1-14, https://doi.org/10.1016/j.quascirev.2012.04.024, 2012.

Müller, P. J., Kirst, G., Ruhland, G., von Storch, I., and Rosell-Melé, A.: Calibration of the alkenone paleotemperature index $U_{37}^{K^{\prime}}$ based on core-tops from the eastern South Atlantic and the global ocean $\left(60^{\circ} \mathrm{N}-60^{\circ} \mathrm{S}\right)$, Geochim. Cosmochim. Ac., 62, 17571772, https://doi.org/10.1016/S0016-7037(98)00097-0, 1998.

Murray, J. W.: Ecology and Applications of Benthic Foraminifera, Cambridge University Press, Cambridge, 440 pp., 2006.

Murton, J. B., Bateman, M. D., Dallimore, S. R., Teller, J. T., and Yang, Z.: Identification of Younger Dryas outburst flood path from Lake Agassiz to the Arctic Ocean, Nature, 464, 740-743, https://doi.org/10.1038/nature08954, 2010.

Newton, A. C. and Rowe, G. T.: The abundance of benthic calcareous Foraminifera and other meiofauna at a time series station in the Northeast Water Polynya, Greenland, J. Geophys. Res., 100, 4423-4438, https://doi.org/10.1029/94JC02356, 1995.

Norwegian Polar Institute: Kartdata Svalbard 1:100 000 (S100 Kartdata)/Map Data [Data set], https://doi.org/10.21334/npolar.2014.645336c7, 2014.

Olsson, I. U.: Content of ${ }^{14} \mathrm{C}$ in marine mammals from Northern Europe, Radiocarbon, 22, 662-675, 1980.

Ottesen, D., Dowdeswell, J. A., Landvik, J. Y., and Mienert, J.: Dynamics of the Late Weichselian ice sheet on Svalbard inferred from high-resolution sea-floor morphology, Boreas, 36, 286306, https://doi.org/10.1111/j.1502-3885.2007.tb01251.x, 2007.

Overland, J., Francis, J. A., Hall, R., Hanna, E., Kim, S.-J., and Vihma, T.: The Melting Arctic and Midlatitude Weather Patterns: Are They Connected?, J. Clim., 28, 7917-7932, https://doi.org/10.1175/JCLI-D-14-00822.1, 2015.

Overland, J. E.: A difficult Arctic science issue: Midlatitude weather linkages, Polar Sci., 10, 210-216, https://doi.org/10.1016/j.polar.2016.04.011, 2015.

Overland, J. E., Dethloff, K., Francis, J. A., Hall, R. J., Hanna, E., Kim, S.-J., Screen, J. A., Shepherd, T. G., and Vihma, T.: Nonlinear response of mid-latitude weather to the changing Arctic, Nat. Clim. Change, 6, 992-999, https://doi.org/10.1038/nclimate3121, 2016.

Overpeck, J. T., Otto-Bliesner, B. L., Miller, G. H., Muhs, D. R., Alley, R. B., and Kiehl, J. T.: Paleoclimatic Evidence for Future IceSheet Instability and Rapid Sea-Level Rise, Science, 311, 17471750, https://doi.org/10.1126/science.1115159, 2006.

Padman, L., Costa, D. P., Dinniman, M. S., Fricker, H. A., Goebel, M. E., Huckstadt, L. A., Humbert, A., Joughin, I., Lenaerts, J. T. M., Ligtenberg, S. R. M., Scambos, T., and Van Den Broeke, M. R.: Oceanic controls on the mass balance of Wilkins Ice Shelf, Antarctica, J. Geophys. Res. Ocean., 117, 1-17, https://doi.org/10.1029/2011JC007301, 2012.

Patterson, R. T. and Fishbein, E.: Re-examination of the statistical methods used to determine the number of point counts needed for micropaleontological quantitative research, J. Paleontol., 63, 245-248, https://doi.org/10.1017/S0022336000019272, 1989.

Pearce, C., Seidenkrantz, M.-S., Kuijpers, A., Massé, G., Reynisson, N. F., and Kristiansen, S. M.: Ocean lead at the termination of the Younger Dryas cold spell, Nat. Commun., 4, 1664, https://doi.org/10.1038/ncomms2686, 2013.
Pearce, C., Seidenkrantz, M.-S., Kuijpers, A., and Reynisson, N. F.: A multi-proxy reconstruction of oceanographic conditions around the Younger Dryas-Holocene transition in Placentia Bay, Newfoundland, Mar. Micropaleontol., 112, 39-49, https://doi.org/10.1016/j.marmicro.2014.08.004, 2014.

Polyak, L., Korsun, S., Febo, L. A., Stanovoy, V., Khusid, T., Hald, M., Paulsen, B. E., and Lubinski, D. J.: Benthic foraminiferal assemblages from the southern Kara Sea, a river-influenced Arctic marine environment, J. Foraminifer. Res., 32, 252-273, https://doi.org/10.2113/32.3.252, 2002.

Porter, S. C. and Denton, G. H.: Chronology of Neoglaciation in the North American Cordillera, Am. J. Sci., 265, 177-210, https://doi.org/10.2475/ajs.265.3.177, 1967.

Prahl, F. G. and Wakeham, S. G.: Calibration of unsaturation patterns in long-chain ketone compositions for palaeotemperature assessment, Nature, 330, 367-369, https://doi.org/10.1038/330367a0, 1987.

Radić, V., Bliss, A., Beedlow, A. C., Hock, R., Miles, E., and Cogley, J. G.: Regional and global projections of twenty-first century glacier mass changes in response to climate scenarios from global climate models, Clim. Dynam., 42, 37-58, https://doi.org/10.1007/s00382-013-1719-7, 2014.

Rasmussen, S. O., Bigler, M., Blockley, S. P., Blunier, T., Buchardt, S. L., Clausen, H. B., Cvijanovic, I., Dahl-Jensen, D., Johnsen, S. J., Fischer, H., Gkinis, V., Guillevic, M., Hoek, W. Z., Lowe, J. J., Pedro, J. B., Popp, T., Seierstad, I. K., Steffensen, J. P., Svensson, A. M., Vallelonga, P., Vinther, B. M., Walker, M. J. C., Wheatley, J. J., and Winstrup, M.: A stratigraphic framework for abrupt climatic changes during the Last Glacial period based on three synchronized Greenland ice-core records: Refining and extending the INTIMATE event stratigraphy, Quaternary Sci. Rev., 106, 14-28, https://doi.org/10.1016/j.quascirev.2014.09.007, 2014.

Rasmussen, T. L. and Thomsen, E.: The role of the North Atlantic Drift in the millennial timescale glacial climate fluctuations, Palaeogeogr. Palaeocl., 210, 101-116, https://doi.org/10.1016/j.palaeo.2004.04.005, 2004.

Rasmussen, T. L. and Thomsen, E.: Pink marine sediments reveal rapid ice melt and Arctic meltwater discharge during Dansgaard-Oeschger warmings, Nat. Commun., 4, 2849, https://doi.org/10.1038/ncomms3849, 2013.

Rasmussen, T. L. and Thomsen, E.: Brine formation in relation to climate changes and ice retreat during the last 15,000 years in Storfjorden, Svalbard, 76-78 N, Paleoceanography, 29, 911929, https://doi.org/10.1002/2014PA002643, 2014.

Rasmussen, T. L., Thomsen, E., Ślubowska, M. A., Jessen, S., Solheim, A., and Koç, N.: Paleoceanographic evolution of the SW Svalbard margin $\left(76^{\circ} \mathrm{N}\right)$ since $20,000{ }^{14} \mathrm{C}$ yr BP, Quat. Res., 67, 100-114, https://doi.org/10.1016/j.yqres.2006.07.002, 2007.

Rasmussen, T. L., Forwick, M., and Mackensen, A.: Reconstruction of inflow of Atlantic Water to Isfjorden, Svalbard during the Holocene: Correlation to climate and seasonality, Mar. Micropaleontol., 94-95, 80-90, https://doi.org/10.1016/j.marmicro.2012.06.008, 2012.

Rasmussen, T. L., Thomsen, E., Skirbekk, K., ŚlubowskaWoldengen, M., Klitgaard Kristensen, D., and Koç, N.: Spatial and temporal distribution of Holocene temperature maxima in the northern Nordic seas: interplay of Atlantic-, Arcticand polar water masses, Quaternary Sci. Rev., 92, 280-291, https://doi.org/10.1016/j.quascirev.2013.10.034, 2014a. 
Rasmussen, T. L., Thomsen, E., and Nielsen, T.: Water mass exchange between the Nordic seas and the Arctic Ocean on millennial timescale during MIS 4-MIS 2, Geochem. Geophys. Geosy., 15, 530-544, https://doi.org/10.1002/2013GC005020, 2014 b.

Reimer, P. J., Bard, E., Bayliss, A., Beck, J. W., Blackwell, P. G., Ramsey, C. B., Buck, C. E., Cheng, H., Edwards, R. L., Friedrich, M., Grootes, P. M., Guilderson, T. P., Haflidason, H., Hajdas, I., Hatté, C., Heaton, T. J., Hoffmann, D. L., Hogg, A. G., Hughen, K. A., Kaiser, K. F., Kromer, B., Manning, S. W., Niu, M., Reimer, R. W., Richards, D. A., Scott, E. M., Southon, J. R., Staff, R. A., Turney, C. S. M., and van der Plicht, J.: IntCal13 and Marine13 Radiocarbon Age Calibration Curves 0-50,000 Years cal BP, Radiocarbon, 55, 1869-1887, https://doi.org/10.2458/azu_js_rc.55.16947, 2013.

Reusche, M., Winsor, K., Carlson, A. E., Marcott, S. A., Rood, D. H., Novak, A., Roof, S., Retelle, M., Werner, A., Caffee, M., and Clark, P. U.: ${ }^{10} \mathrm{Be}$ surface exposure ages on the late-Pleistocene and Holocene history of Linnébreen on Svalbard, Quaternary Sci. Rev., 89, 5-12, https://doi.org/10.1016/j.quascirev.2014.01.017, 2014.

Rigual-Hernández, A. S., Colmenero-Hidalgo, E., Martrat, B., Bárcena, M. A., de Vernal, A., Sierro, F. J., Flores, J. A., Grimalt, J. O., Henry, M., and Lucchi, R. G.: Svalbard icesheet decay after the Last Glacial Maximum: New insights from micropalaeontological and organic biomarker paleoceanographical reconstructions, Palaeogeogr. Palaeocl., 465, 225-236, https://doi.org/10.1016/j.palaeo.2016.10.034, 2017.

Rinterknecht, V., Jomelli, V., Brunstein, D., Favier, V., MassonDelmotte, V., Bourlès, D., Leanni, L., and Schläppy, R.: Unstable ice stream in Greenland during the Younger Dryas cold event, Geology, 42, 759-762, https://doi.org/10.1130/G35929.1, 2014.

Risebrobakken, B., Dokken, T., Smedsrud, L. H., Andersson, C., Jansen, E., Moros, M., and Ivanova, E. V.: Early Holocene temperature variability in the Nordic Seas: The role of oceanic heat advection versus changes in orbital forcing, Paleoceanography, 26, PA4206, https://doi.org/10.1029/2011PA002117, 2011.

Rudels, B.: Arctic ocean circulation, in Encyclopedia of Ocean Sciences, edited by: Steele, J. H., Turekian, K. K., and Thorpe, S. A., 211-225, Elsevier, 2009.

Rytter, F., Knudsen, K. L., Seidenkrantz, M.-S., and Eiriksson, J.: Modern Distribution of Benthic Foraminifera on the North Icelandinc Shelf and Slope, J. Foraminifer. Res., 32, 217-244, https://doi.org/10.2113/32.3.217, 2002.

Sakshaug, E.: Biomass and productivity distributions and their variability in the Barents Sea, ICES J. Mar. Sci., 54, 341-350, https://doi.org/10.1006/jmsc.1996.0170, 1997.

Saloranta, T. M. and Haugan, P. M.: Interannual variability in the hydrography of Atlantic water northwest of Svalbard, J. Geophys. Res., 106, 13931-13943, https://doi.org/10.1029/2000JC000478, 2001.

Saloranta, T. M. and Svendsen, H.: Across the Arctic front west of Spitsbergen: High-resolution CTD sections from 19982000, Polar Res., 20, 177-184, https://doi.org/10.1111/j.17518369.2001.tb00054.x, 2001.

Salvigsen, O.: Radiocarbon-dated Mytilus edulis and Modiolus modiolus from northern Svalbard: Climatic implications, Nor. J. Geogr., 56, 56-61, https://doi.org/10.1080/002919502760056350, 2002.
Salvigsen, O. and Høgvard, K.: Glacial history, Holocene shoreline displacement and palaeoclimate based on radiocarbon ages in the area of Bockfjorden, north-western Spitsbergen, Svalbard, Polar Res., 25, 15-24, https://doi.org/10.1111/j.17518369.2005.tb00021.x, 2006.

Salvigsen, O. and Österholm, H.: Radiocarbon dated raised beaches and glacial history of the northern coast of Spitsbergen, Svalbard, Polar Res., 1982, 97-115, https://doi.org/10.1111/j.17518369.1982.tb00473.x, 1982.

Sarnthein, M., van Kreveld, S., Erlenkeuser, H., Grootes, P. M., Kucera, M., Pflaumann, U., and Schulz, M.: Centennial-tomillennial-scale periodicities of Holocene climate and sediment injections off the western Barents shelf, $75^{\circ} \mathrm{N}$, Boreas, 32, 447461, https://doi.org/10.1080/03009480310003351, 2003.

Schauer, U., Fahrbach, E., Osterhus, S., and Rohardt, G.: Arctic warming through the Fram Strait: Oceanic heat transport from 3 years of measurements, J. Geophys. Res. C Ocean., 109, 1-14, https://doi.org/10.1029/2003JC001823, 2004.

Schlitzer, R.: Ocean Data View, available at: http://odv.awi.de (last access: 23 November 2017), 2015.

Seidenkrantz, M.-S.: Cassidulina teretis Tappan and Cassidulina neoteretis new species (Foraminifera): stratigraphic markers for deep sea and outer shelf areas, J. Micropalaeontology, 14, 145157, https://doi.org/10.1144/jm.14.2.145, 1995.

Seidenkrantz, M.-S.: Benthic foraminifera as palaeo sea-ice indicators in the subarctic realm - examples from the Labrador Sea-Baffin Bay region, Quaternary Sci. Rev., 79, 135-144, https://doi.org/10.1016/j.quascirev.2013.03.014, 2013.

Seidenkrantz, M.-S., Ebbesen, H., Aagaard-Sørensen, S., Moros, M., Lloyd, J. M., Olsen, J., Knudsen, M. F., and Kuijpers, A.: Early Holocene large-scale meltwater discharge from Greenland documented by foraminifera and sediment parameters, Palaeogeogr. Palaeocl., 391, 71-81, https://doi.org/10.1016/j.palaeo.2012.04.006, 2013.

Serreze, M. C. and Barry, R. G.: Processes and impacts of Arctic amplification: A research synthesis, Global Planet. Change, 77, 85-96, https://doi.org/10.1016/j.gloplacha.2011.03.004, 2011.

Serreze, M. C., Barrett, A. P., Slater, A. G., Woodgate, R. A., Aagaard, K., Lammers, R. B., Steele, M., Moritz, R., Meredith, M., and Lee, C. M.: The large-scale freshwater cycle of the Arctic, J. Geophys. Res. Ocean., 111, 1-19, https://doi.org/10.1029/2005JC003424, 2006.

Shackleton, N. J.: Attainment of isotopic equilibrium between ocean water and the benthonic foraminifera Uvigerina: isotopic changes in the ocean during the last glacial, Colloq. Int. du C.N.R.S, 219, 203-209, available at: https://epic.awi.de/32862/ 1/shackleton-1974.pdf (last access: 23 November 2017), 1974.

Sheldon, C., Jennings, A., Andrews, J. T., Ó Cofaigh, C., Hogan, K., Dowdeswell, J. A., and Seidenkrantz, M. S.: Ice stream retreat following the LGM and onset of the west Greenland current in Uummannaq Trough, west Greenland, Quaternary Sci. Rev., 147, 27-46, https://doi.org/10.1016/j.quascirev.2016.01.019, 2016a.

Sheldon, C. M., Seidenkrantz, M.-S., Pearce, C., Kuijpers, A., Hansen, M. J., and Christensen, E. Z.: Holocene oceanographic changes in SW Labrador Sea, off Newfoundland, The Holocene, 26, 274-289, https://doi.org/10.1177/0959683615608690, $2016 b$.

Skirbekk, K., Klitgaard Kristensen, D., Rasmussen, T. L., Koç, N., and Forwick, M.: Holocene climate variations at the entrance to 
a warm Arctic fjord: evidence from Kongsfjorden trough, Svalbard, in Fjord Systems and Archives, vol. 344, edited by: Howe, J. A., Austin, W. E. N., Forwick, M., and Paetzel, M., 289-304, Geological Society, London, 2010.

Skogseth, R., Haugan, P. M., and Jakobsson, M.: Watermass transformations in Storfjorden, Cont. Shelf Res., 25, 667-695, https://doi.org/10.1016/j.csr.2004.10.005, 2005.

Ślubowska-Woldengen, M., Rasmussen, T. L., Koç, N., KlitgaardKristensen, D., Nilsen, F., and Solheim, A.: Advection of Atlantic Water to the western and northern Svalbard shelf since 17,500 cal yr BP, Quaternary Sci. Rev., 26, 463-478, https://doi.org/10.1016/j.quascirev.2006.09.009, 2007.

Ślubowska-Woldengen, M., Koç, N., Rasmussen, T. L., KlitgaardKristensen, D., Hald, M., and Jennings, A. E.: Time-slice reconstructions of ocean circulation changes on the continental shelf in the Nordic and Barents Seas during the last 16,000 cal yr B.P., Quaternary Sci. Rev., 27, 1476-1492, https://doi.org/10.1016/j.quascirev.2008.04.015, 2008.

Ślubowska, M. A., Koç, N., Rasmussen, T. L., and KlitgaardKristensen, D.: Changes in the flow of Atlantic water into the Arctic Ocean since the last deglaciation: Evidence from the northern Svalbard continental margin, $80^{\circ} \mathrm{N}$ Paleoceanography, 20, https://doi.org/10.1029/2005PA001141, 2005.

Small, D. and Fabel, D.: Was Scotland deglaciated during the Younger Dryas?, Quaternary Sci. Rev., 145, 259-263, https://doi.org/10.1016/j.quascirev.2016.05.031, 2016.

Smik, L., Cabedo-Sanz, P., and Belt, S. T.: Semi-quantitative estimates of paleo Arctic sea ice concentration based on sourcespecific highly branched isoprenoid alkenes: A further development of the $\mathrm{PIP}_{25}$ index, Org. Geochem., 92, 63-69, https://doi.org/10.1016/j.orggeochem.2015.12.007, 2016.

Solomina, O. N., Bradley, R. S., Hodgson, D. A., IvyOchs, S., Jomelli, V., Mackintosh, A. N., Nesje, A., Owen, L. A., Wanner, H., Wiles, G. C., and Young, N. E.: Holocene glacier fluctuations, Quaternary Sci. Rev., 111, 9-34, https://doi.org/10.1016/j.quascirev.2014.11.018, 2015.

Solomina, O. N., Bradley, R. S., Jomelli, V., Geirsdottir, A., Kaufman, D. S., Koch, J., McKay, N. P., Masiokas, M., Miller, G., Nesje, A., Nicolussi, K., Owen, L. A., Putnam, A. E., Wanner, H., Wiles, G., and Yang, B.: Glacier fluctuations during the past 2000 years, Quaternary Sci. Rev., 149, 61-90, https://doi.org/10.1016/j.quascirev.2016.04.008, 2016.

Spielhagen, R. F., Werner, K., Sørensen, S. A., Zamelczyk, K., Kandiano, E., Budeus, G., Husum, K., Marchitto, T. M., and Hald, M.: Enhanced modern heat transfer to the Arctic by warm Atlantic Water., Science, 331, 450-453, https://doi.org/10.1126/science.1197397, 2011.

Stalling, D., Westerhof, M., and Hege, H.-C.: Amira: A Highly Interactive System for Visual Data Analysis, in The Visualization Handbook, edited by: Hansen, C. D. and Johnson, C. R., 749767, Elsevier, available at: https://amira.zib.de/ (last access: 23 November 2017), 2005.

Stein, R., Fahl, K., and Müller, J.: Proxy Reconstruction of Cenozoic Arctic Ocean Sea-Ice History - from IRD to $\mathrm{IP}_{25}$, Polarforschung, 82, 37-71, 2012.

Steinsund, P. I.: Benthic foraminifera in surface sediments of the Barents and Kara Seas: modern and late Quaternary applications, PhD thesis, 1994.
Stokes, C. R., Corner, G. D., Winsborrow, M. C. M., Husum, K., and Andreassen, K.: Asynchronous response of marine-terminating outlet glaciers during deglaciation of the Fennoscandian ice sheet, Geology, 42, 455-458, https://doi.org/10.1130/G35299.1, 2014.

Straneo, F., Hamilton, G. S., Sutherland, D. A., Stearns, L. A., Davidson, F., Hammill, M. O., Stenson, G. B., and RosingAsvid, A.: Rapid circulation of warm subtropical waters in a major glacial fjord in East Greenland, Nat. Geosci., 3, 182-186, https://doi.org/10.1038/ngeo764, 2010.

Stroeve, J. C., Serreze, M. C., Holland, M. M., Kay, J. E., Malanik, J., and Barrett, A. P.: The Arctic's rapidly shrinking sea ice cover: A research synthesis, Clim. Change, 110, 1005-1027, https://doi.org/10.1007/s10584-011-0101-1, 2012.

Svendsen, J. I., Elverhøi, A., and Mangerud, J.: The retreat of the Barents Sea Ice Sheet on the western Svalbard margin, Boreas, 25, 244-256, https://doi.org/10.1111/j.15023885.1996.tb00640.x, 1996.

Svendsen, J. I., Gataullin, V., Mangerud, J., and Polyak, L.: The glacial History of the Barents and Kara Sea Region, in Quaternary Glaciations-Extent and Chronology, edited by: Ehlers, J. and Gibbard, P. L., 369-378, Elsevier, Amsterdam, 2004.

Szczuciński, W., and Zajączkowski, M.: Factors Controlling Downward Fluxes of Particulate Matter in Glacier-Contact and NonGlacier Contact Settings in a Subpolar Fjord (Billefjorden, Svalbard), in Sediments, Morphology and Sedimentary Processes on Continental Shelves, vol. 44, edited by: Li, M. Z., Sherwood, C. R., and Hill, P. R., 369-386, John Wiley \& Sons, Ltd, Chichester, West Sussex, UK, 2012.

Taldenkova, E., Bauch, H. A., Gottschalk, J., Nikolaev, S., Rostovtseva, Y., Pogodina, I., Ovsepyan, Y., and Kandiano, E.: History of ice-rafting and water mass evolution at the northern Siberian continental margin (Laptev Sea) during Late Glacial and Holocene times, Quaternary Sci. Rev., 29, 3919-3935, https://doi.org/10.1016/j.quascirev.2010.09.013, 2010.

Tarasov, L. and Peltier, W. R.: Arctic freshwater forcing of the Younger Dryas cold reversal, Nature, 435, 662-665, https://doi.org/10.1038/nature03617, 2005.

Teigen, S. H., Nilsen, F., Skogseth, R., Gjevik, B., and Beszczynska-Möller, A.: Barotropic instability in the West Spitsbergen Current, J. Geophys. Res.-Ocean., 116, 1-18, https://doi.org/10.1029/2011JC006974, 2010.

Telesiński, M. M., Bauch, H. A., Spielhagen, R. F., and Kandiano, E. S.: Evolution of the central Nordic Seas over the last 20 thousand years, Quaternary Sci. Rev., 121, 98-109, https://doi.org/10.1016/j.quascirev.2015.05.013, 2015.

van der Bilt, W. G. M., D’Andrea, W. J., Bakke, J., Balascio, N. L., Werner, J. P., Gjerde, M., and Bradley, R. S.: Alkenone-based reconstructions reveal four-phase Holocene temperature evolution for High Arctic Svalbard, Quaternary Sci. Rev., in press, https://doi.org/10.1016/j.quascirev.2016.10.006, 2016.

Volkman, J. K.: A review of sterol markers for marine and terrigenous organic matter, Org. Geochem., 9, 83-99, https://doi.org/10.1016/0146-6380(86)90089-6, 1986.

Volkman, J. K., Barrett, S. M., Dunstan, G. A., and Jeffrey, S. W.: Geochemical significance of the occurrence of dinosterol and other 4-methyl sterols in a marine diatom, Org. Geochem., 20, 7-15, https://doi.org/10.1016/0146-6380(93)90076-N, 1993. 
von Appen, W.-J., Schauer, U., Hattermann, T., and BeszczynskaMöller, A.: Seasonal Cycle of Mesoscale Instability of the West Spitsbergen Current, J. Phys. Oceanogr., 46, 1231-1254, https://doi.org/10.1175/JPO-D-15-0184.1, 2016.

Waelbroeck, C., Duplessy, J. C., Michel, E., Labeyrie, L., Paillard, D., and Duprat, J.: The timing of the last deglaciation in North Atlantic climate records, Nature, 412, 724-727, https://doi.org/10.1038/35106623, 2001.

Waelbroeck, C., Labeyrie, L., Michel, E., Duplessy, J. C., McManus, J. F., Lambeck, K., Balbon, E., and Labracherie, M.: Sealevel and deep water temperature changes derived from benthic foraminifera isotopic records, Quaternary Sci. Rev., 21, 295-305, https://doi.org/10.1016/S0277-3791(01)00101-9, 2002.

Walczowski, W.: Frontal structures in the West Spitsbergen current margins, Ocean Sci., 9, 957-975, https://doi.org/10.5194/os-9957-2013, 2013.

Wassmann, P.: Overarching perspectives of contemporary and future ecosystems in the Arctic Ocean, Prog. Oceanogr., 139, 1-12, https://doi.org/10.1016/j.pocean.2015.08.004, 2015.

Werner, K., Spielhagen, R. F., Bauch, D., Hass, H. C., Kandiano, E., and Zamelczyk, K.: Atlantic Water advection to the eastern Fram Strait - Multiproxy evidence for late Holocene variability, Palaeogeogr. Palaeocl., 308, 264-276, https://doi.org/10.1016/j.palaeo.2011.05.030, 2011.

Werner, K., Spielhagen, R. F., Bauch, D., Hass, H. C., and Kandiano, E.: Atlantic Water advection versus sea-ice advances in the eastern Fram Strait during the last $9 \mathrm{ka}$ : Multiproxy evidence for a two-phase Holocene, Paleoceanography, 28, 283295, https://doi.org/10.1002/palo.20028, 2013.
Werner, K., Frank, M., Teschner, C., Müller, J., and Spielhagen, R. F.: Neoglacial change in deep water exchange and increase of sea-ice transport through eastern Fram Strait?: evidence from radiogenic isotopes, Quaternary Sci. Rev., 92, 190-207, https://doi.org/10.1016/j.quascirev.2013.06.015, 2014.

Werner, K., Müller, J., Husum, K., Spielhagen, R. F., Kandiano, E. S., and Polyak, L.: Holocene sea subsurface and surface water masses in the Fram Strait - Comparisons of temperature and sea-ice reconstructions, Quaternary Sci. Rev., 147, 194-209, https://doi.org/10.1016/j.quascirev.2015.09.007, 2016.

Wollenburg, J. E., Knies, J., and Mackensen, A.: High-resolution paleoproductivity fluctuations during the past $24 \mathrm{kyr}$ as indicated by benthic foraminifera in the marginal Arctic Ocean, Palaeogeogr. Palaeocl., 204, 209-238, https://doi.org/10.1016/S00310182(03)00726-0, 2004.

Wouters, B., Martin-Espanol, A., Helm, V., Flament, T., van Wessem, J. M., Ligtenberg, S. R. M., van den Broeke, M. R., and Bamber, J. L.: Dynamic thinning of glaciers on the Southern Antarctic Peninsula, Science, 348, 899-903, https://doi.org/10.1126/science.aaa5727, 2015.

Xiao, X., Fahl, K., Müller, J., and Stein, R.: Sea-ice distribution in the modern Arctic Ocean: Biomarker records from trans-Arctic Ocean surface sediments, Geochim. Cosmochim. Acta, 155, 1629, https://doi.org/10.1016/j.gca.2015.01.029, 2015.

Zajączkowski, M., Szczuciński, W., Plessen, B., and Jernas, P.: Benthic foraminifera in Hornsund, Svalbard: Implications for paleoenvironmental reconstructions, Polish Polar Res., 31, 349-375, https://doi.org/10.2478/v10183-010-0010-4, 2010. 